\title{
Low Activity Waste Feed Solids Characterization and Filterability Tests
}

Charles L. Crawford

Mark R. Duignan

Michael R. Williams

Paul R. Burket

Daniel J. McCabe

March, 2014

SRNL-STI-2014-00126, Rev. 0 
SRNL-STI-2014-00126

Revision 0

\section{DISCLAIMER}

This work was prepared under an agreement with and funded by the U.S. Government. Neither the U.S. Government or its employees, nor any of its contractors, subcontractors or their employees, makes any express or implied:

1. warranty or assumes any legal liability for the accuracy, completeness, or for the use or results of such use of any information, product, or process disclosed; or

2. representation that such use or results of such use would not infringe privately owned rights; or

3. endorsement or recommendation of any specifically identified commercial product, process, or service.

Any views and opinions of authors expressed in this work do not necessarily state or reflect those of the United States Government, or its contractors, or subcontractors.

\section{Printed in the United States of America \\ Prepared for U.S. Department of Energy}


Keywords: Ion Exchange

Technetium

Low Activity Waste

Precipitation

Retention: Permanent

\section{Low Activity Waste Feed Solids Characterization and Filterability Tests}

Charles L. Crawford

Mark R. Duignan

Michael R. Williams

Paul R. Burket

Daniel J. McCabe

March, 2014 


\section{REVIEWS AND APPROVALS}

\section{AUTHORS:}

Charles L. Crawford, Process Technology Programs

Date

Mark R. Duignan, Engineering Process Development

Date

Michael R. Williams, Process Technology Programs

Date

Paul R. Burket, Engineering Process Development

Date

Daniel J. McCabe, Advanced Characterization and Process Research

Date

TECHNICAL REVIEW:

Charles A. Nash, Advanced Characterization and Process Research,

Reviewed per E7 Manual, Procedure 2.60

Date

APPROVAL:

F.M. Pennebaker, Manager

Date

Advanced Characterization and Process Research

S. L. Marra, Manager

Date

Environmental \& Chemical Process Technology Research Programs

R.A. Robbins, Manager

Date

Washington River Protection Solutions 


\section{EXECUTIVE SUMMARY}

The primary treatment of the tank waste at the DOE Hanford site will be done in the Waste Treatment and Immobilization Plant (WTP) that is currently under construction. The baseline plan for the WTP Pretreatment facility is to treat the waste, splitting it into High Level Waste (HLW) feed and Low Activity Waste (LAW) feed. Both waste streams are then separately vitrified as glass and sealed in canisters. The LAW glass will be disposed onsite in the Integrated Disposal Facility (IDF). There are currently no plans to treat the waste to remove technetium in the WTP Pretreatment facility, so its disposition path is the LAW glass. Options are being explored to immobilize the LAW portion of the tank waste, i.e., the LAW feed from the WTP Pretreatment facility. Removal of ${ }^{99} \mathrm{Tc}$ from the LAW Feed, followed by off-site disposal of the ${ }^{99} \mathrm{Tc}$, would eliminate a key risk contributor for the IDF Performance Assessment (PA) for supplemental waste forms, and has potential to reduce treatment and disposal costs. Washington River Protection Solutions (WRPS) is developing some conceptual flow sheets for LAW treatment and disposal that could benefit from technetium removal. One of these flowsheets will specifically examine removing ${ }^{99} \mathrm{Tc}$ from the LAW feed stream to supplemental immobilization. The conceptual flow sheet of the ${ }^{99} \mathrm{Tc}$ removal process includes a filter to remove insoluble solids prior to processing the stream in an ion exchange column, but the characteristics and behavior of the liquid and solid phases has not previously been investigated.

This report contains results of testing of a simulant that represents the projected composition of the feed to the Supplemental LAW process. This feed composition is not identical to the aqueous tank waste fed to the Waste Treatment Plant because it has been processed through WTP Pretreatment facility and therefore contains internal changes and recycle streams that will be generated within the WTP process. Although a Supplemental LAW feed simulant has previously been prepared, this feed composition differs from that simulant because those tests examined only the fully soluble aqueous solution at room temperature, not the composition formed after evaporation, including the insoluble solids that precipitate after it cools. The conceptual flow sheet for Supplemental LAW immobilization has an option for removal of ${ }^{99} \mathrm{Tc}$ from the feed stream, if needed. Elutable ion exchange has been selected for that process. If implemented, the stream would need filtration to remove the insoluble solids prior to processing in an ion exchange column. The characteristics, chemical speciation, physical properties, and filterability of the solids are important to judge the feasibility of the concept, and to estimate the size and cost of a facility.

The insoluble solids formed during these tests were primarily natrophosphate, natroxalate, and a sodium aluminosilicate compound. At the elevated temperature and $8 \mathrm{M}\left[\mathrm{Na}^{+}\right]$, appreciable insoluble solids $(1.39 \mathrm{wt} \%)$ were present. Cooling to room temperature and dilution of the slurry from $8 \mathrm{M}$ to $\left.5 \mathrm{M}^{2} \mathrm{Na}^{+}\right]$resulted in a slurry containing $0.8 \mathrm{wt} \%$ insoluble solids. The solids (natrophosphate, natroxalate, sodium aluminum silicate, and a hydrated sodium phosphate) were relatively stable and settled quickly. Filtration rates were in the range of those observed with

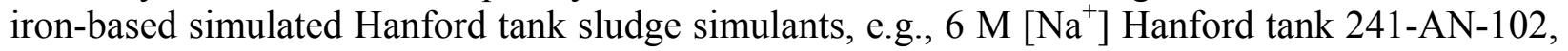
even though their chemical speciation is considerably different. Chemical cleaning of the crossflow filter was readily accomplished with acid.

As this simulant formulation was based on an average composition of a wide range of feeds using an integrated computer model, this exact composition may never be observed. But the test conditions were selected to enable comparison to the model to enable improving its chemical prediction capability. 


\section{TABLE OF CONTENTS}

LIST OF TABLES vii

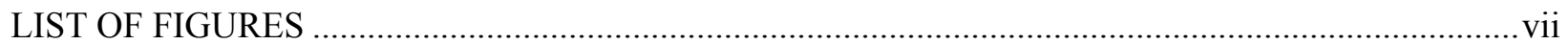

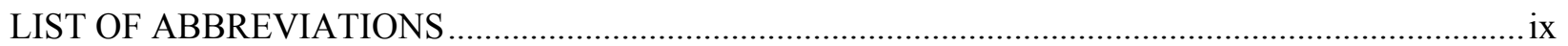

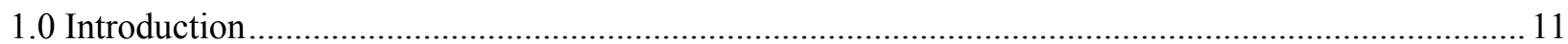

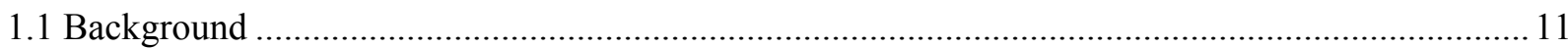

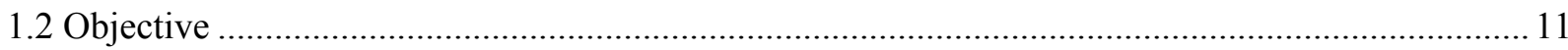

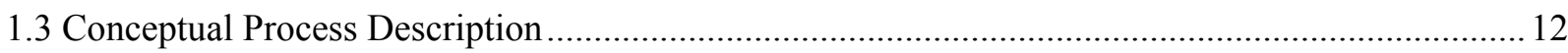

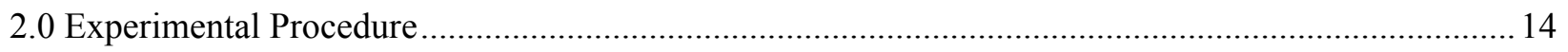

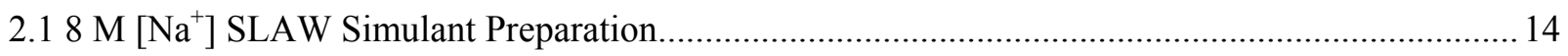

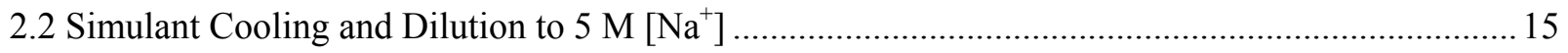

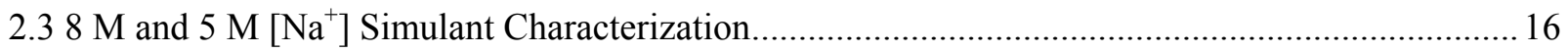

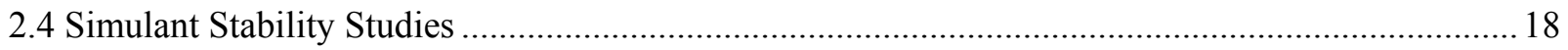

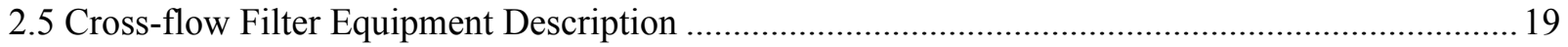

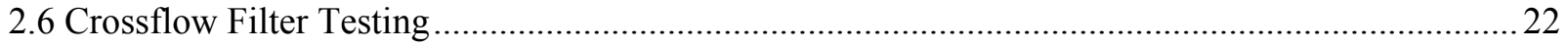

2.7 Cross-flow Filter Chemical Cleaning and Clean Water Flux......................................................24

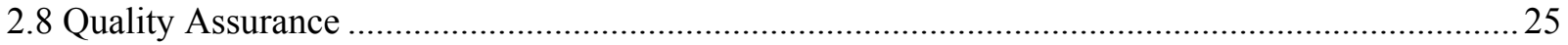

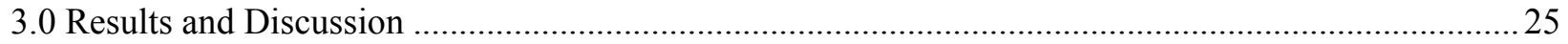

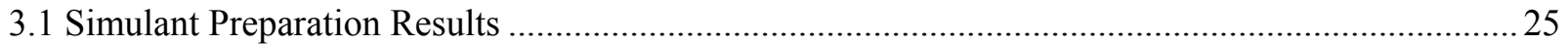

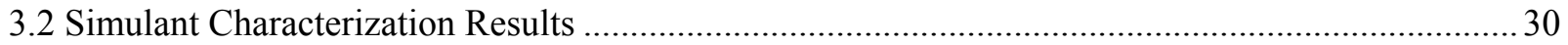

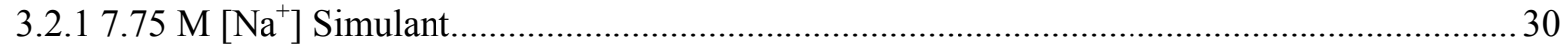

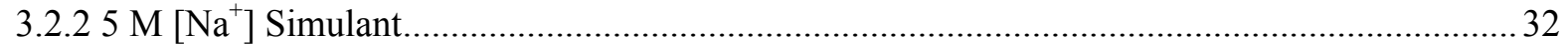

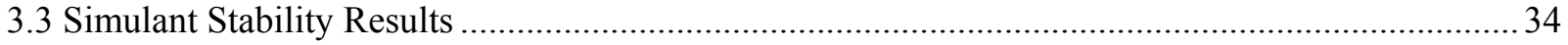

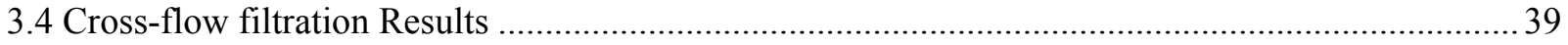

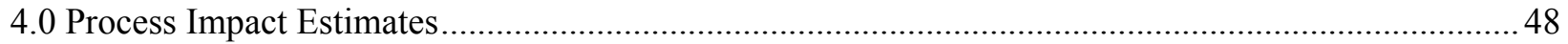

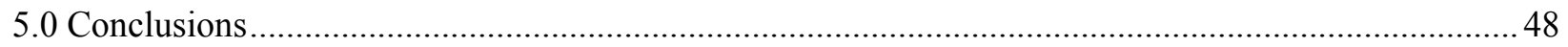

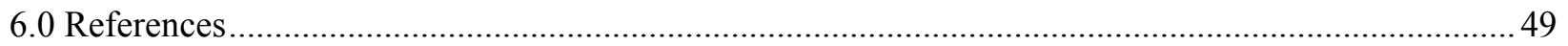

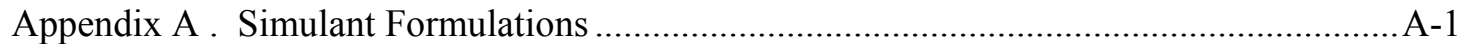

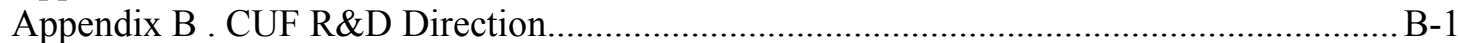

Appendix C . CUF Test Matrix and Detailed Summary of Test Steps .................................. C-1

Appendix D . Filtrate Measurement Device ................................................................... D-1 


\section{LIST OF TABLES}

Table 1-1 HTWOS Average "8 M" Simulant Target Molar Composition ................................................ 13

Table 2-1 Characterization and Analyses of the Simulants ...................................................................... 18

Table 2-2 Repeat measurements of inside Diameter (inch) of CUF filter tube …...................................20

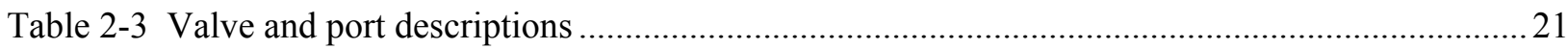

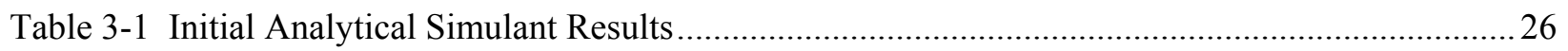

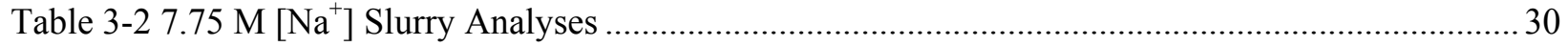

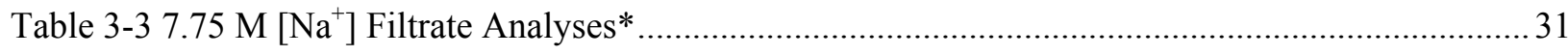

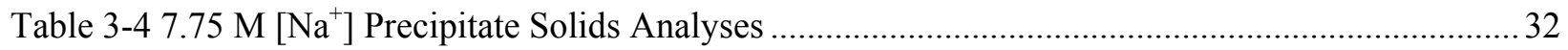

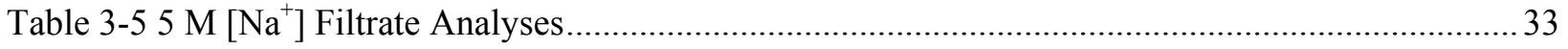

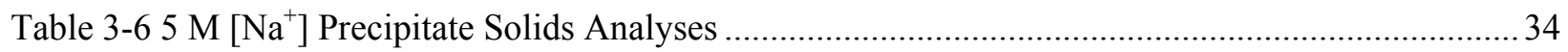

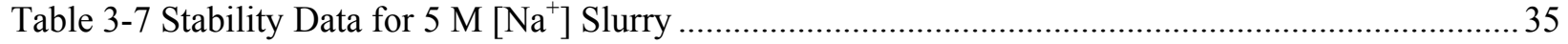

Table 3-8 Analytical Results for CUF Filtrate and Slurry Samples...................................................... 45

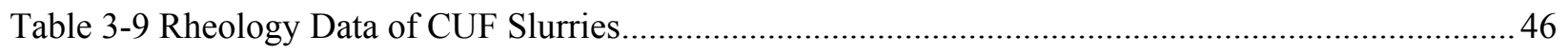

Table 3-10 Comparison between two different filter tests.................................................................... 47

\section{LIST OF FIGURES}

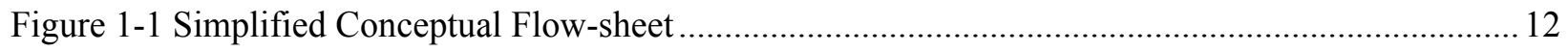

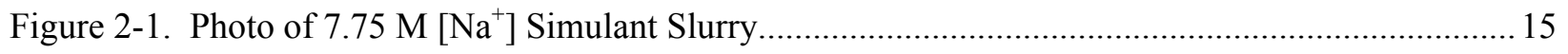

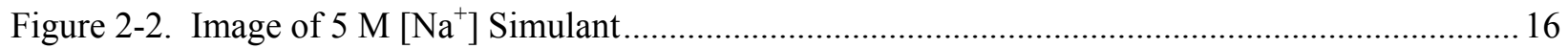

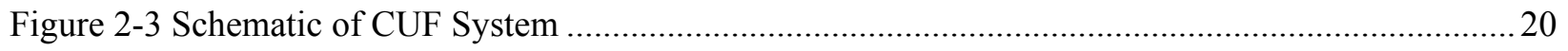

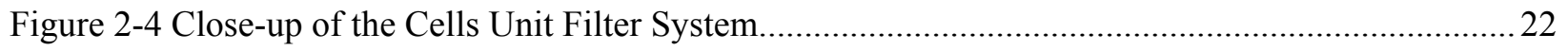

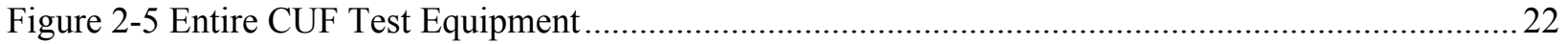

Figure 2-6 Grey solids adhered to bottom of CUF feed tank............................................................. 23

Figure 2-7 Deionized and Filtered Water Flux before and after test ....................................................24

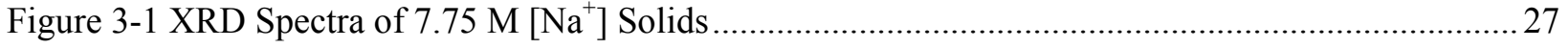

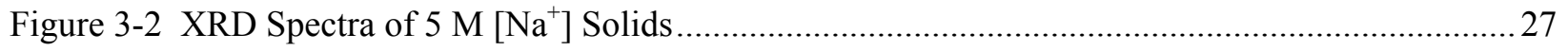

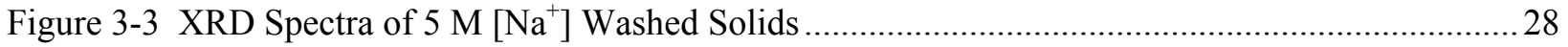

Figure 3-4 XRD Spectra of 7.75 M [ $\left.\mathrm{Na}^{+}\right]$Solids Excluding Cancrinite ................................................28 


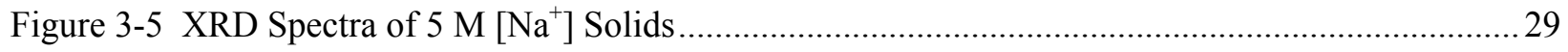

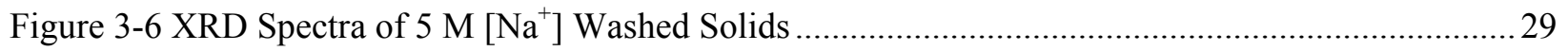

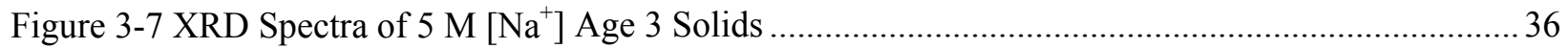

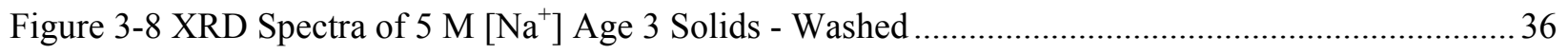

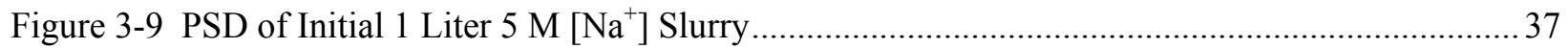

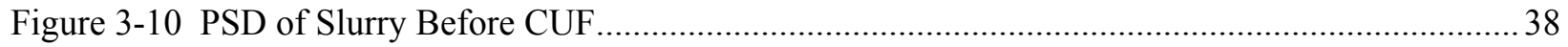

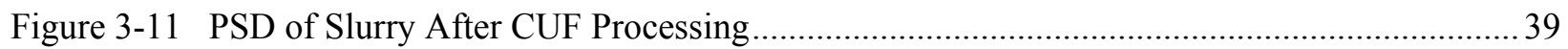

Figure 3-12 Dead-end filters used, $0.45 \mu \mathrm{m}$ pore, to pre-concentrate simulant....................................... 40

Figure 3-13 TMP and Slurry Axial Velocity during test - downtimes excluded ................................... 41

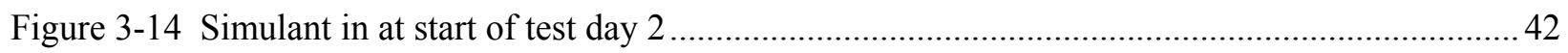

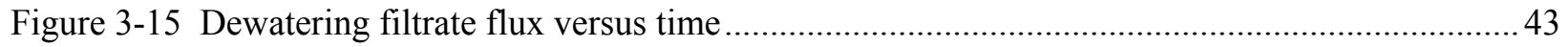

Figure 3-16 Dewatering filtrate flux versus measured solids loading ................................................. 44

Figure 3-17 Crossflow filtration of two simulants: two batches of Hanford $6 \mathrm{M}\left[\mathrm{Na}^{+}\right] \mathrm{AN}-102$ waste to

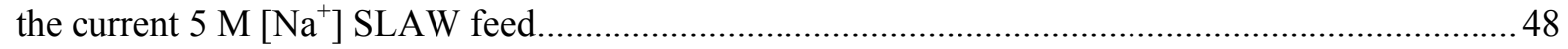




\section{LIST OF ABBREVIATIONS}

$\begin{array}{ll}\text { ASTM } & \text { American Society of Testing and Materials } \\ \mathrm{BV} & \text { Bed Volumes - Height of IX column occupied by IX resin } \\ { }^{\circ} \mathrm{C} & \text { Celsius } \\ \mathrm{C} & \text { Concentration } \\ \mathrm{cP} & \text { centipoise } \\ \mathrm{CUF} & \text { Cells Unit Filter - Experimental filtration rig used for present test } \\ \text { DIF } & \text { Deionized and Filtered (Water) } \\ \text { DOE } & \text { U.S. Department of Energy } \\ \mathrm{ft} & \text { Foot } \\ \mathrm{g} & \text { gram } \\ \text { gal } & \text { gallon } \\ \text { gpm } & \text { gallons per minute } \\ \mathrm{HLW} & \text { High Level Waste } \\ \mathrm{hr} & \text { hour } \\ \mathrm{HTWOS} & \text { Hanford Tank Waste Operations Simulator } \\ \mathrm{ICP}-\mathrm{ES} & \text { Inductively Coupled Plasma Emission Spectroscopy } \\ \mathrm{ICP}-\mathrm{MS} & \text { Inductively Coupled Plasma Mass Spectroscopy } \\ \mathrm{ID} & \text { Internal Diameter } \\ \mathrm{IDF} & \text { Integrated Disposal Facility } \\ \text { in } & \text { inch } \\ \mathrm{IS} & \text { Insoluble Solids } \\ \mathrm{IX} & \text { Ion Exchange } \\ \mathrm{K}_{\mathrm{d}} & \text { Distribution Coefficient } \\ \mathrm{L} & \text { Liter } \\ \text { LAW } & \text { Low Activity Waste } \\ \mathrm{M} & \text { Molarity } \\ \mathrm{m} & \text { meter } \\ \mu & \text { Dynamic Viscosity (cP) } \\ \mathrm{mA} & \text { milliamp } \\ \mathrm{mg} & \text { milligram } \\ \mathrm{min} & \text { minute } \\ \mathrm{mL} & \text { milliliter } \\ \mathrm{M} & \text { Molarity } \\ \mathrm{MN} & \text { Mean Number (particle size measurements) } \\ \mathrm{MV} & \text { Mean Volume (particle size measurements) } \\ & \end{array}$




$\begin{array}{ll}\text { NA } & \text { Not Applicable } \\ \text { NM } & \text { Not Measured } \\ \text { PA } & \text { Performance Assessment } \\ \text { pH } & \text { Measure of acidity or basicity of an aqueous solution } \\ \text { psi } & \text { Pressure - Pounds Per Square Inch } \\ \text { psid } & \text { Differential Pressure } \\ \text { psig } & \text { Gauge Pressure } \\ \rho & \text { Density (g/ml) } \\ \text { SLAW } & \text { Supplemental Low Activity Waste } \\ \text { SRNL } & \text { Savannah River National Laboratory } \\ \text { SV } & \text { axial Slurry Velocity through crossflow filter tube } \\ \text { TIC } & \text { Total Inorganic Carbon } \\ \text { TMP } & \text { Transmembrane pressure: [P2 +(P2-P1)/2] }+ \text { P3 } \\ \text { TOC } & \text { Total Organic Carbon } \\ \text { wt\% } & \text { weight percent } \\ \text { WRPS } & \text { Washington River Protection Solutions } \\ \text { WTP } & \text { Waste Treatment and Immobilization Plant } \\ \text { XRD } & \text { X-ray Diffraction }\end{array}$




\subsection{Introduction}

\subsection{Background}

Savannah River National Laboratory (SRNL) is performing studies on behalf of Washington River Protection Solutions (WRPS) to support the disposition of tank waste at the DOE Hanford site near Richland, Washington. The primary treatment of the tank waste will be done in the Waste Treatment and Immobilization Plant (WTP) that is currently under construction. The baseline plan for this facility is to treat the waste, splitting it into High Level Waste (HLW) and Low Activity Waste (LAW). Both waste streams are then separately vitrified as glass and sealed in canisters. The LAW glass is the disposition path for the soluble ${ }^{99} \mathrm{Tc}$, and it will be disposed onsite in the Integrated Disposal Facility (IDF). Because ${ }^{99} \mathrm{Tc}$ has a very long half-life $(211,000$ years) and is highly mobile [Icenhower et al., 2008, 2010], it has potential to be a major dose contributor to the Performance Assessment (PA) of the IDF [Mann et al., 2003]. Due to the soluble properties of pertechnetate, and the potential for impact to the PA, effective management of ${ }^{99} \mathrm{Tc}$ is important to the overall success of the River Protection Project mission.

Technetium in the tank waste is predominantly found in the tank supernate as pertechnetate $\left(\mathrm{TcO}_{4}^{-}\right)$, although there is also a soluble ${ }^{99} \mathrm{Tc}$ species that is not pertechnetate ("nonpertechnetate"), and some insoluble technetium, which is presumably Tc(IV) oxide. Technology development for ${ }^{99} \mathrm{Tc}$ removal has focused on pertechnetate separations. No methods have been developed that can remove the soluble non-pertechnetate specie(s) unless first destroyed and converted to pertechnetate. The insoluble technetium oxide is removed by filtration.

\subsection{Objective}

Options are being explored to immobilize the LAW feed portion of the tank waste after pretreatment in the WTP Pretreatment facility, as well as to examine the volatility of technetium during the vitrification process. Removal of ${ }^{99} \mathrm{Tc}$, followed by off-site disposal of technetium from the LAW, would eliminate a key risk contributor for the IDF PA for supplemental waste forms, and has potential to reduce treatment and disposal costs. WRPS is developing some conceptual flow sheets for LAW treatment and disposal that could benefit from technetium removal. One of these flow-sheets will specifically examine removing ${ }^{99} \mathrm{Tc}$ from the LAW feed stream to supplemental LAW immobilization using ion exchange. To enable an informed decision on the viability of technetium removal, further development of available technologies is underway.

To process a stream through an ion exchange column, the insoluble solids must be removed in order to avoid fouling the resin bed. In radioactive environments, this is typically performed using cross-flow sintered stainless steel filters, such as those used at the SRS Actinide Removal Process (ARP) [Poirier, 2002]. These filters have the advantage of resistance to chemical and radiolytic degradation, remote handling, chemical cleaning, and high solids capacity. Filtration rate cannot be predicted with any accuracy without testing on the material, since it is dependent on the morphology, concentration, and particle size of the solids. Testing of the filter performance with representative simulants provides data for estimating the size of the filter, 
measuring physical properties of the concentrated solids slurry, and examining the effectiveness of chemically cleaning the filter.

The objective of this task is to quantify and characterize the solids that form in this waste stream to enable adequate sizing of the filter prior to the Tc IX process and to determine methods for stabilization of these solids in supplemental immobilization. The stream will be generated within WTP at the exit of the Pretreatment Facility after an evaporator, and is at $8 \mathrm{M}\left[\mathrm{Na}^{+}\right]$and $45^{\circ} \mathrm{C}$. To process in the Tc IX system, the stream will be diluted and cooled to $5 \mathrm{M}\left[\mathrm{Na}^{+}\right]$and $25^{\circ} \mathrm{C}$, which is expected to cause formation of insoluble solids that may precipitate slowly.

\subsection{Conceptual Process Description}

In the proposed conceptual flowsheet [RPP-RPT-55855], the stream from the LAW evaporator is diluted and cooled, the insoluble solids are removed by filtration, and the ${ }^{99} \mathrm{Tc}$ is removed from the aqueous phase. The solids are washed in the filter to remove interstitial liquid containing Tc, and then recombined with the aqueous phase and disposed together in an immobilization process (Figure 1-1). It is therefore important to also examine the chemistry and physical properties of the insoluble solids so that the feasibility of this concept can be verified.

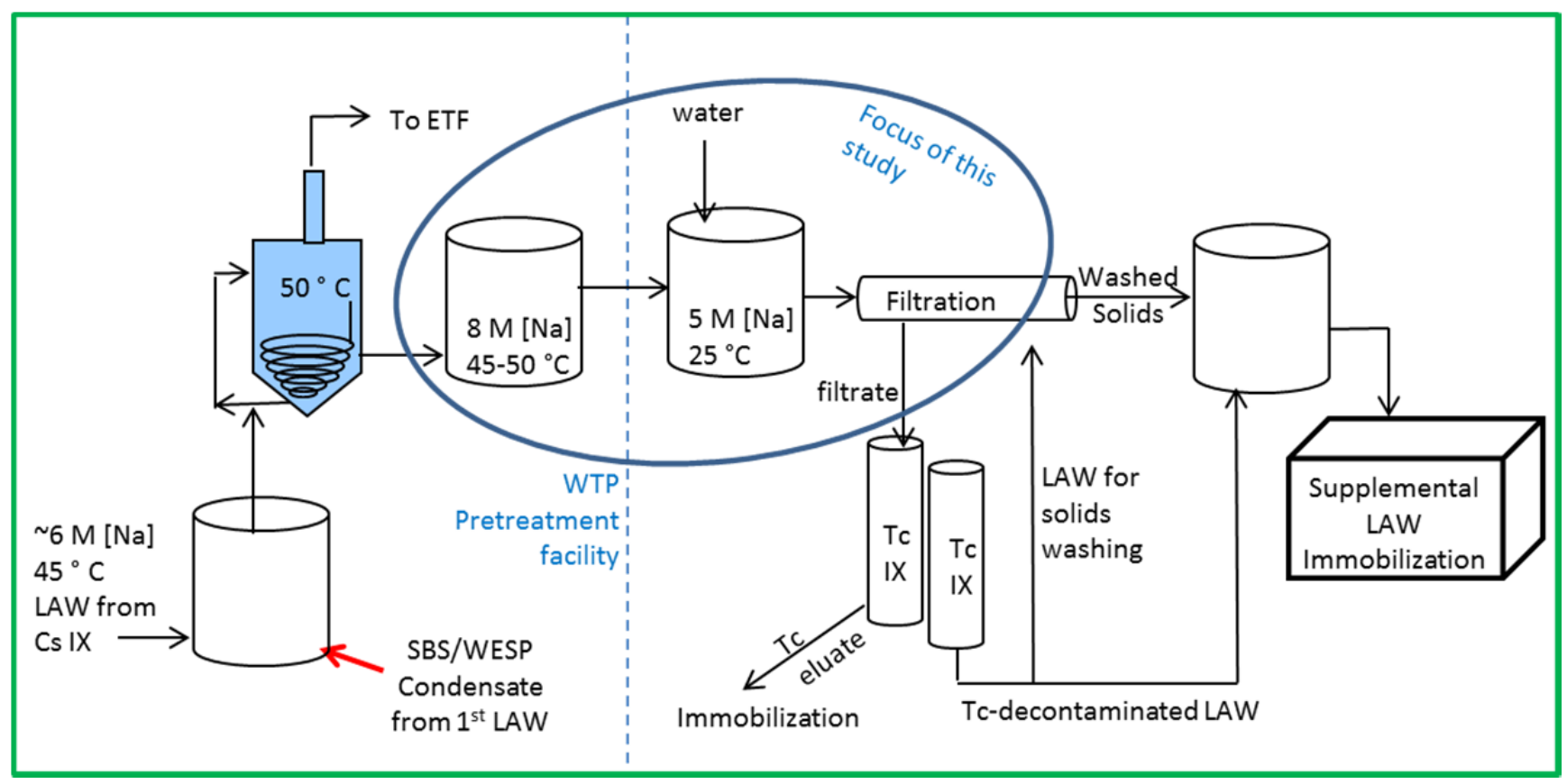

Figure 1-1 Simplified Conceptual Flow-sheet

This waste stream will not be available for sampling and characterization until the WTP begins operation. Although pilot-scale testing has been performed with simulants, the basis for the WTP feed simulant formulation was different and the recycle of melter off-gas did not encompass the full range of expected conditions. The earlier work focused on the composition in several Double Shell Tank wastes, and did not include material from the full range of Single Shell Tanks. The basis for the simulant formulation used in this work is therefore based on a computer model run of the Hanford Tank Waste Operations Simulator (HTWOS) [version 7.4, Belsher, 2012]. The current composition is based on an overall average over the life of the WTP 
mission. That composition was derived from a run of the HTWOS computer model, with results documented in SVF-2748.

The Feed stream calculated in SVF-2748 is the exit stream from the Pretreatment Facility to a future Supplemental LAW (SLAW) immobilization facility. The last process step in WTP is evaporation, which concentrates the stream to $\sim 8 \mathrm{M}\left[\mathrm{Na}^{+}\right]$and is at $45{ }^{\circ} \mathrm{C}$. The composition of major constituents in the SLAW Feed from the SVF-2748 model output is shown in Table 11, Table 1-1 HTWOS Average "8 M" Simulant Target Molar Composition which is actually calculated to be $\sim 7.8 \mathrm{M}\left[\mathrm{Na}^{+}\right]$with this anion concentration, including both soluble and insoluble sodium salts (7.75 $\mathrm{M}\left[\mathrm{Na}^{+}\right], 7.8 \mathrm{M}$ total cations).

\section{Table 1-1 HTWOS Average “8 M” Simulant Target Molar Composition}

\begin{tabular}{ll} 
Ion & Molarity \\
\hline $\mathrm{NO}_{3}{ }^{-}$ & 2.427 \\
$\mathrm{OH}^{-}$(free) & 2.149 \\
$\mathrm{SO}_{4}{ }^{-2}$ & 0.110 \\
$\mathrm{Al}(\mathrm{OH})_{4}^{-}$ & 0.527 \\
$\mathrm{NO}_{2}^{-}$ & 0.960 \\
$\mathrm{CO}_{3}{ }^{-2}$ & 0.357 \\
$\mathrm{~K}^{+}$ & 0.0520 \\
$\mathrm{Acetate}^{-}$ & 0.0620 \\
$\mathrm{~F}^{-}$ & 0.192 \\
$\mathrm{PO}_{4}{ }^{-3}$ & 0.118 \\
$\mathrm{Cl}^{-}$ & 0.0700 \\
$\mathrm{SiO}_{3}{ }^{-2}$ & 0.0290 \\
Oxalate & 0.0360
\end{tabular}

The SVF-2748 output includes an appreciable concentration of chromate in this stream. However, since it would be completely soluble and therefore not impact the outcome of insoluble solids studies, it was omitted from the preparation to avoid production of a chromiumhazardous waste. Minor constituents $(<5 \mathrm{mg} / \mathrm{L})$, even if insoluble, would also not impact the outcome because they would be overwhelmed by the physical properties of the bulk constituents, and were likewise excluded.

The original WTP flowsheet included Tc IX in the pre-treatment facility, where it followed the Cs IX process step. In this original flowsheet, the waste feed to the ion-exchange units was anticipated to be $5 \mathrm{M}\left[\mathrm{Na}^{+}\right]$and $25{ }^{\circ} \mathrm{C}$ and consequently all the technology maturation activities associated with the technetium ion-exchange system were conducted under these conditions. In the current flowsheet [RPP-RPT-55855], the feed from WTP Pretreatment to Supplemental LAW will be $\sim 8 \mathrm{M}\left[\mathrm{Na}^{+}\right]$and $45{ }^{\circ} \mathrm{C}$. The Tc IX technology has not been demonstrated under these conditions and it is expected that operation at $\sim 8 \mathrm{M}\left[\mathrm{Na}^{+}\right]$would cause the resin to float in the dense fluid, fluidizing the resin bed and reducing the decontamination factor [McCabe, 2013]. Similarly, operation at $45{ }^{\circ} \mathrm{C}$ would decrease the capacity of the ion exchange resin, reducing its ${ }^{99} \mathrm{Tc}$ removal performance. Therefore to ensure optimal Tc IX operational conditions, the WTP 
Supplemental LAW stream in the proposed conceptual Tc removal flowsheet will be diluted and cooled, which may result in formation of additional insoluble solids. Additional testing could be performed to examine other conditions and system configurations to accommodate buoyant resin, but this has not yet been done. Information described in this report on the baseline conditions will be used to make a decision about the optimum conditions and configuration to accomplish the goal of removing the ${ }^{99} \mathrm{Tc}$.

\subsection{Experimental Procedure}

\section{$2.1 \underline{8 \mathrm{M}\left[\mathrm{Na}^{+}\right] \text {SLAW Simulant Preparation }}$}

The initial simulant target ion concentrations were obtained from the HTWOS model run SVF2748 , and average values were provided by WRPS. The target composition was then converted to a formulation that could be created from laboratory chemicals. The SVF-2748 separately tracks oxalate and Total Organic Carbon (TOC) species. Oxalate was added at the SVF-2748 calculated output level, and acetate was used as the species providing the TOC content $(0.124 \mathrm{M}$ as TOC). Acetate is quite soluble in water, and is therefore expected to be completely soluble in this matrix, but oxalate has limited solubility. In this work a 1-liter simulant was first prepared at the $7.75 \mathrm{M}\left[\mathrm{Na}^{+}\right]$target at $45{ }^{\circ} \mathrm{C}$ using the formulation of batch chemicals shown in Appendix A that were mixed/heated in a 1-liter volumetric flask on a heater stir plate. The purpose of this initial small 1-liter scale simulant preparation was to provide an "analytical sample" used for preliminary characterization focused on the amount of insoluble solids present and to establish the sequence of chemical and water additions. Sodium or potassium salts were typically used as the starting chemicals, except for the aluminum hydroxide which was generated in the simulant slurry by reaction of aluminum nitrate and sodium hydroxide solution. During the preparation, the temperature was maintained at $45-50{ }^{\circ} \mathrm{C}$ by stirring the batch on a hot plate and controlling the rate of addition of chemicals. The formulation in Appendix A shows that soluble salts were initially added to water, followed by caustic addition and dissolution of the aluminum nitrate. A

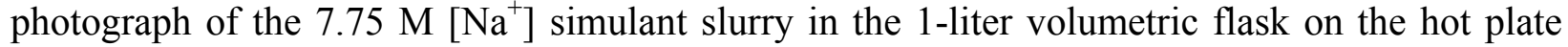
showing suspended white solids during stirring and heating is shown in Figure 2-1. The small diameter stainless steel thermocouple probe seen in the photograph is submerged into the slurry to allow for constant temperature monitoring. After addition of the chemicals and dilution to the 1-liter mark on the volumetric flask, the slurry was maintained at $45^{\circ} \mathrm{C}$ for at least six hours. The density was obtained for this slurry at $45^{\circ} \mathrm{C}$ by measuring the total mass of the 1-liter sample. Samples of the $7.75 \mathrm{M}\left[\mathrm{Na}^{+}\right]$slurry for physical and chemical characterization were also obtained from the well-mixed slurry while at temperature. 


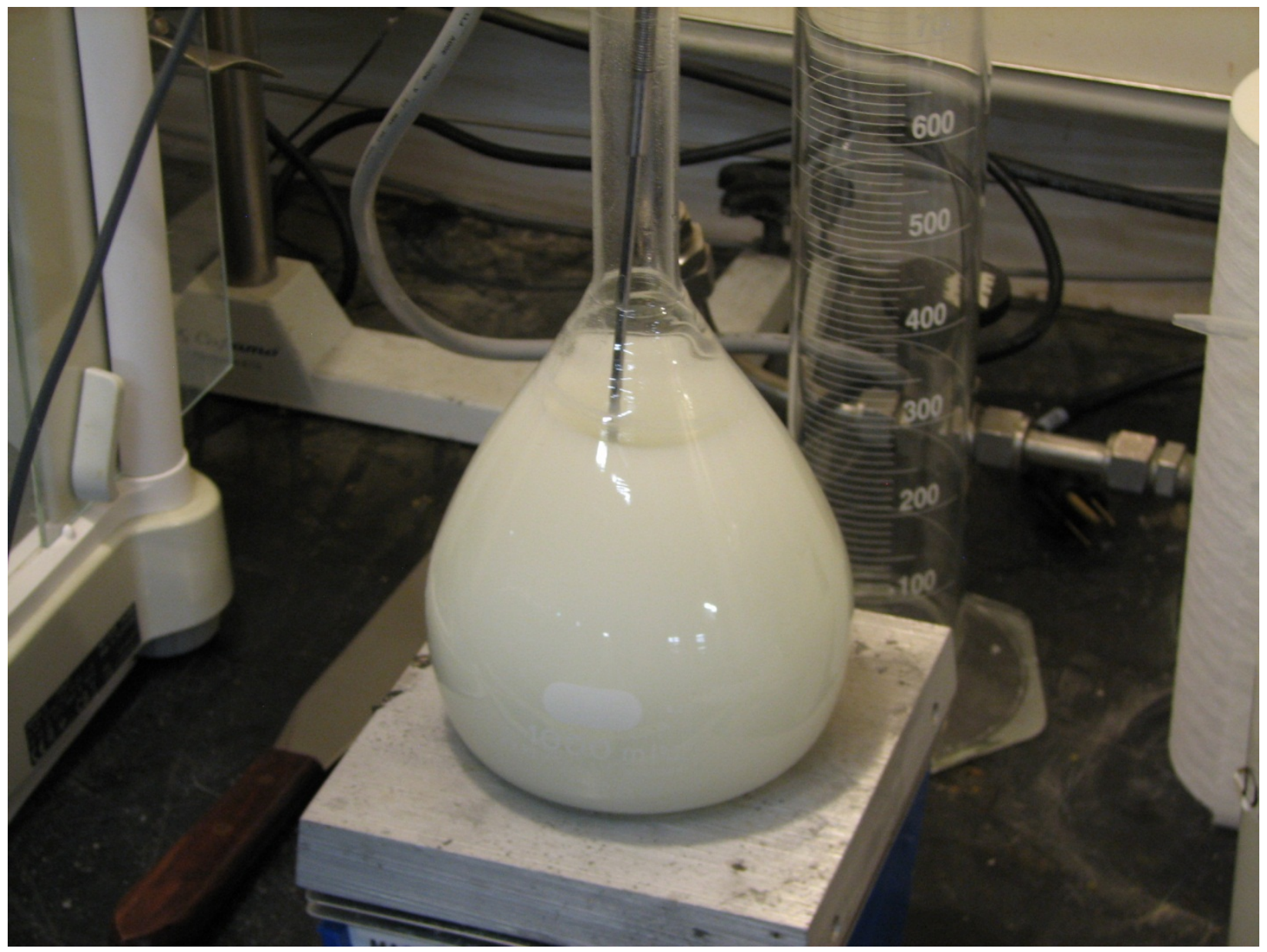

Figure 2-1. Photo of $7.75 \mathrm{M}\left[\mathrm{Na}^{+}\right]$Simulant Slurry

This 1-Liter batch of simulant was used as the batching formulation basis for the larger scale simulant batches that were prepared for the Cells Unit Filter (CUF) system, which involved scale up to either 5-liter or 15-liter final $\left(5 \mathrm{M}\left[\mathrm{Na}^{+}\right]\right)$batch sizes. To obtain the 5 liter batch, a 3.2-liter batch was prepared at $7.75 \mathrm{M} \mathrm{Na}$ and then cooled and diluted to 5 liters, and the 15-liter batch was prepared as a the 9.6-liter batch at $7.75 \mathrm{M}\left[\mathrm{Na}^{+}\right]$that was then cooled and diluted to 15 liters. Details are shown in Appendix A. The 5-liter batch was initially prepared in a 4-liter glass beaker at $7.84 \mathrm{M}\left[\mathrm{Na}^{+}\right]$before cooling, transfer to a 5-gal stainless steel pot, and dilution to $5 \mathrm{M}$ $\left[\mathrm{Na}^{+}\right]$. The larger 15-liter product batch was initially prepared in the 5-gal stainless steel pot, then cooled and diluted to $5 \mathrm{M}\left[\mathrm{Na}^{+}\right]$in the same pot. Both of these larger scale simulant batches were made using the same chemical addition sequence as the smaller 1-liter simulant, and heating at $45-50{ }^{\circ} \mathrm{C}$ was maintained by both a hot plate and controlled rate of addition of chemicals.

\subsection{Simulant Cooling and Dilution to $5 \mathrm{M}\left[\mathrm{Na}^{+}\right]$}

After maintaining the $8 \mathrm{M}$ simulant batches at $45 \pm 5^{\circ} \mathrm{C}$ for at least 6 hours, they were allowed to cool to ambient temperature, i.e., $25 \pm 5^{\circ} \mathrm{C}$ overnight. Deionized water was added to reach a calculated $5 \mathrm{M}\left[\mathrm{Na}^{+}\right]$total soluble and insoluble sodium salts. The final $5 \mathrm{M}\left[\mathrm{Na}^{+}\right]$simulant 
slurries were stirred for several hours before either sampling (for the small volume analytical sample) or preparation for the CUF (for the 5-liter and 15-liter batches). After all the $\left.5 \mathrm{M}^{2} \mathrm{Na}^{+}\right]$ slurry samples had been taken from the well-mixed small scale analytical sample, mixing was stopped and the solids were allowed to settle. Figure 2-2 shows a photograph of the $5 \mathrm{M}\left[\mathrm{Na}^{+}\right]$ slurry analytical sample with the solids settled to a thin layer at the bottom of the 2-liter glass beaker.

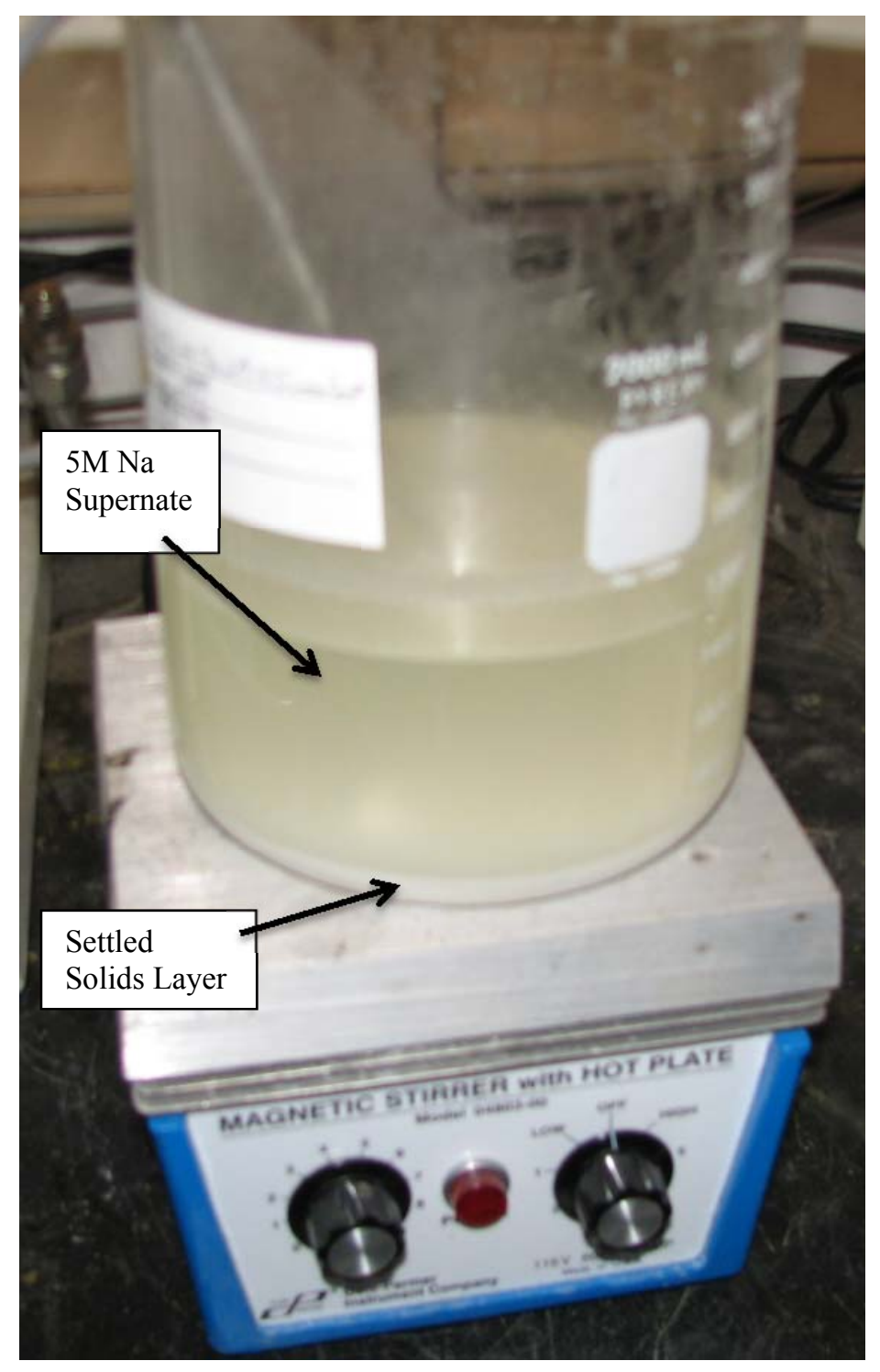

Figure 2-2. Image of $5 \mathrm{M}\left[\mathrm{Na}^{+}\right]$Simulant

\section{$2.3 \underline{8 \mathrm{M} \text { and } 5 \mathrm{M}\left[\mathrm{Na}^{+}\right] \text {Simulant Characterization }}$}

Both the $7.75 \mathrm{M}\left[\mathrm{Na}^{+}\right]$slurry and the cooled and diluted $\left.5 \mathrm{M}^{2} \mathrm{Na}^{+}\right]$slurry were analyzed according to the methods shown in Table 2-1. The table cells with a check mark $(\sqrt{ })$ indicate 
analyses that were performed and those cells with a 'Not Analyzed' or NA indicate samples where the methods were not applied. Aliquots of the $7.75 \mathrm{M}\left[\mathrm{Na}^{+}\right]$slurry were obtained while the slurry was being mixed at $45^{\circ} \mathrm{C}$. Some of the aliquots were promptly filtered using $0.45 \mu \mathrm{m}$ nylon filters to create the solids and filtrate samples. Similar sampling was performed on the cooled and diluted $5 \mathrm{M}\left[\mathrm{Na}^{+}\right]$well-mixed slurry. All filtered solids used in either dissolution and analysis or total solids measurements were taken from the air-dried solids on top of the filter media, i.e., no washing or drying with heat of the solids was performed. Analyses were performed in duplicate.

Dissolution methods used on the slurries and filtrates involved mixing nominally $3 \mathrm{~g}$ of sample (slurry or filtrate) and $5 \mathrm{~mL}$ of concentrated nitric acid, followed by dilution of the acidified samples with deionized (DI) water to $50 \mathrm{~mL}$ total volume. The samples were heated to $115^{\circ} \mathrm{C}$ for 2 hours in sealed Teflon ${ }^{\circledR}$ vessels. Dissolution of the filtered solids was similar but only used nominally $0.3 \mathrm{~g}$ of air-dried filtered solids. The dissolved samples were analyzed by Inductively Coupled Plasma Atomic Emission Spectroscopy (ICP-AES). All anions analyses were performed on non-dissolved filtrates using Ion Chromatography (IC). The weight \% total solids $\left(\mathrm{W}_{\mathrm{ts}}\right)$ for the slurries and the weight \% dissolved solids $\left(\mathrm{W}_{\mathrm{ds}}\right)$ for the filtrates were determined by drying small quantities at $110{ }^{\circ} \mathrm{C}$ until less than $0.005 \mathrm{~g}$ mass change was observed on subsequent heating and weighing cycles. An equation was then used to calculate the weight $\%$ insoluble solids ( $\mathrm{W}_{\text {is }}$ ) using Equation 1 [Pareizs, 2012]:

$\mathrm{W}_{\text {is }}=\left(\mathrm{W}_{\mathrm{ts}}-\mathrm{W}_{\mathrm{ds}}\right) /\left(1-\mathrm{W}_{\mathrm{ds}}\right)$

Equation 1

Particle size distributions (PSD) of the $5 \mathrm{M}$ slurries were obtained using a Microtrac S3500 diffraction analysis instrument capable of measuring particle diameters in the range of 0.243 to $1408 \mu \mathrm{m}$. This instrument quantifies particle diameters based on the portion of light scattered when a laser beam is projected through a fluid containing suspended solid phase particles. The amount and direction of light scattered by the particles is measured by an optical detector array and then analyzed to determine the PSD. PSD results were reported on a volume distribution basis and a number distribution basis. Volume distributions provide a means for assessing large particles, since large particles contribute most to the volume. In contrast, number distributions provide a means for evaluating small particles which can be abundant but contribute little to the volume. Mean particle diameters associated with the volume distributions (MV) and number distributions $(\mathrm{MN})$ were also calculated and reported. The mean particle diameter associated with the volume distribution is denoted as "mv' and represents the "center of gravity" of the distribution. This quantity is considered the average particle size contributing to the volume. The mean particle diameter associated with the number distribution is denoted as ' $m n$ ' and represents the average particle size contributing to the population.

X-ray diffraction (XRD) was performed on filtered solids to investigate crystalline species associated with the insoluble solids. Certain filtered solids were also washed with deionized water to investigate post-washed solids remaining on the filter. Carbon analyses comprised of Total Inorganic Carbon (TIC), Total Organic Carbon (TOC) and Total Carbon (TC) were performed to analyze the various carbon species present in the simulant such as carbonate (TIC) and acetate and oxalate (TOC). 
In addition to the detailed analyses performed on the analytical simulant discussed above, limited analysis was also performed on many of the samples collected during the CUF tests. Slurries and filtrates were obtained for total solids so the $\mathrm{wt} \%$ IS values could be determined to track slurry concentration in the CUF. Filtrate samples were also obtained during dewatering steps to measure the density and soluble components by ICP-AES.

Rheological measurements were obtained using a Haake VT550 viscometer, M5 measuring head and a MV1 rotor. This Haake is a controlled rate rheometer. The MV1 rotor was used to complete all of the rheological measurements. The MV1, which is a concentric cylinder, was used to measure the flow curves for the slurries. Prior to using the MV1 rotor for measurement of the slurry samples, the system was functionally calibrated using a $95.6 \mathrm{cp}$ oil standard at $25^{\circ} \mathrm{C}$. Procedure 2.16, "Haake Rheometer", Technical Reference ITS/TNX Procedure Manual was used to operate the Haake rheometer. Prior to starting any measurements, the rotors and cups were inspected for physical damage. The system was then functionally calibrated using an oil standard at $25{ }^{\circ} \mathrm{C}$. The system was considered functionally calibrated when the measured viscosity was within $\pm 10 \%$ of the oil standard. The sample bottle was shaken to homogenize the sample prior to placing the sample into the cup. If air bubbles were noticed prior to pouring out the sample, the sample bottle was swished to assist in bubble removal. After the sample had been placed into the cup and the cup installed into the Hake, the sample was immediately run. The measurement method was a ramp from $0-1000 \mathrm{~s}^{-1}$ over five minutes, a 60 second hold, and a down ramp from 1000-0 s ${ }^{-1}$ over five minutes. The Bingham Plastic Model of the down curve of the method was used to calculate a plastic viscosity and yield stress. Further details of the rheology measurement instrumentation have been previously reported, e.g., see Table E.1: 'Haake Specifications and Measuring Ranges' in Hansen and Calloway, 2000.

Table 2-1 Characterization and Analyses of the Simulants

\begin{tabular}{|c|c|c|c|c|c|c|}
\hline Methods & $\begin{array}{c}7.75 \mathrm{M} \\
\text { Slurry }\end{array}$ & $\begin{array}{c}7.75 \mathrm{M} \\
\text { Solids }\end{array}$ & $\begin{array}{c}7.75 \mathrm{M} \\
\text { Filtrate }\end{array}$ & $5 \mathrm{M}$ Slurry & 5 M Solids & 5 Filtrate \\
\hline $\begin{array}{c}\text { Dissolution / } \\
\text { Metals Analysis }\end{array}$ & $\sqrt{ }$ & $\sqrt{ }$ & $\sqrt{ }$ & NA & $\sqrt{ }$ & $\sqrt{ }$ \\
\hline Anions & $\sqrt{ }$ & $\sqrt{ }$ & $\sqrt{ }$ & NA & $\sqrt{ }$ & $\sqrt{ }$ \\
\hline Weight \% Solids & $\sqrt{ }$ & NA & $\sqrt{ }$ & $\sqrt{ }$ & NA & $\sqrt{ }$ \\
\hline Density & $\sqrt{ }$ & NA & $\sqrt{ }$ & $\sqrt{ }$ & NA & NA \\
\hline $\begin{array}{c}\text { Particle Size } \\
\text { Distribution }\end{array}$ & NA & NA & NA & $\sqrt{ }$ & NA \\
\hline XRD & NA & $\sqrt{ }$ & NA & NA & $\sqrt{ }$ & $\sqrt{ }$ \\
\hline TIC/TOC/TC & $\sqrt{ }$ & $\sqrt{ }$ & $\sqrt{ }$ & NA & NA & NA \\
\hline Rheology & NA & NA & NA & $\sqrt{ }$ & N \\
\hline
\end{tabular}

\subsection{Simulant Stability Studies}

The $5 \mathrm{M}\left[\mathrm{Na}^{+}\right]$sample was held at $25{ }^{\circ} \mathrm{C}$ and subsequent samples were analyzed up to a tenweek duration (late October 2013 through early January 2014) to investigate the stability of this simulant. Weight \% total solids on both the slurry and filtrate, metals analysis of the filtrate via 
ICP-AES, and XRD of the filtered precipitate solids were performed on these 'aged' samples for comparison to the initial $5 \mathrm{M}\left[\mathrm{Na}^{+}\right]$sample.

\subsection{Cross-flow Filter Equipment Description}

To evaluate the SLAW-Feed simulant for filterability, a Cells Unit Filter (CUF) system was utilized. The CUF employs a single crossflow filter membrane similar to the original one designed at SRNL (Nash, 1995) to filter samples of radioactive wastes with a small enough footprint that it could fit in a Shielded Cells enclosure. It is a very useful tool to compare the filter performance of different waste streams. Since its first use, the CUF has evolved and basically became a DOE Complex standard to measure filterability. The principal difference among all the existing CUF rigs is the specifics of the crossflow filter element. The element can be made by different manufacturers, have different pore sizes, (e.g., 0.5, 0.2, and $0.1 \mu \mathrm{m}$ are common pore ratings), different internal diameters (e.g., 0.5, 0.375, and 0.25 inches are common inside diameters), or lengths (e.g., 24, 18, and 12 inches are common). There are many other variables, such as media wall thickness, homogeneous or non-homogeneous media structure, media materials of construction, etc. The exact parameters chosen are generally based on the solids being filtered, existing equipment, size restrictions, needed performance, etc. However, the most common size and media used for the CUF has been the 0.375 -in ID, 2-ft long, $0.1 \mu \mathrm{m}$ rated filter media from Mott Inc. (for example: Nash et al., 2000; Brooks et al., 2000; Zamecnik et al., 2002, 2003, and 2004b; Poirier et al., 2003; Mann et al., 2004; Duignan et al., 2011). While the footprint and waste volume needed makes a CUF a convenient tool, there are certain non-prototypic features that should be remembered when considering data produced from this device. The principal CUF filter length is 24 inches, which is much shorter than full-scale filters that tend to be 4-6 times longer. These differences cause the pressure and axial slurry velocity (SV) end effects to be greater in the CUF. In most cases the CUF only has a single tube as compared to plant facilities that will have multiple, and sometimes hundreds, of elements. This means most of the pump energy for the CUF is applied to single filter element instead of many. However, the CUF has been shown to be useful to the measure crossflow filter performance when compared to more prototypic facilities (Zamecnik et al., 2004a; Daniel et al., 2010), so long as these parameters are accounted in the comparisons.

The CUF utilized in this test consisted of a single Mott industrial grade $0.1 \mu \mathrm{m}$ tube filter, 24 inches long, with a 3/8-inch inside diameter, and a 1/16-inch thick wall. Furthermore, the media is of a homogeneous design, meaning the sintered $316 \mathrm{~L}$ stainless steel pore structure is the same throughout the filter wall thickness. The tubes manufacturer's identification number was 7610081-001. To calculate the filtration surface area, the inside diameter provided by the manufacturer was used. Because of its design, the inside diameter could not be measured more than within an inch of either end of the tube ends, but those ends were measured in four places with the results shown in Table 2-2. Since the manufacturer's dimension of 0.375 inch is very close to the measured mean value, the manufacturer's value was used because of the limited number of accessible measurement locations. Therefore, the filter dimensions provide a calculated filter surface area to be $0.196 \mathrm{ft}^{2}$. 
SRNL-STI-2014-00126

Revision 0

Table 2-2 Repeat measurements of inside Diameter (inch) of CUF filter tube

\begin{tabular}{|c|c|}
\hline No. & I.D. \\
\hline 1 & 0.373 \\
\hline 2 & 0.380 \\
\hline 3 & 0.382 \\
\hline 4 & 0.370 \\
\hline Mean & 0.376 \\
\hline Std. Dev. & 0.006 \\
\hline
\end{tabular}

The other principal features of the CUF system, shown in Figure 2-3 are the Feed tank, (capacity of $\sim 8$ liters), slurry pump and its $1.7 \mathrm{hp}$ air-driven motor, slurry magnetic flowmeter, heat exchanger (to remove the pump heat), air-driven backpulse system, and graduated cylinder (to measure the filtrate flow - see Appendix D for an explanation of this measurement). At the maximum power output of the pump motor, the Price Pump Co. MS50 multistage centrifugal pump can put out approximately $6 \mathrm{gpm}$ at $40 \mathrm{psig}$. This was projected to be sufficient for this test because the superficial velocity (SV) needed was $11 \mathrm{ft} / \mathrm{s}$, or $3.8 \mathrm{gpm}$ at standard operational conditions and $16 \mathrm{ft} / \mathrm{s}$, or $5.5 \mathrm{gpm}$, for scouring conditions (which is explained in Appendix C).

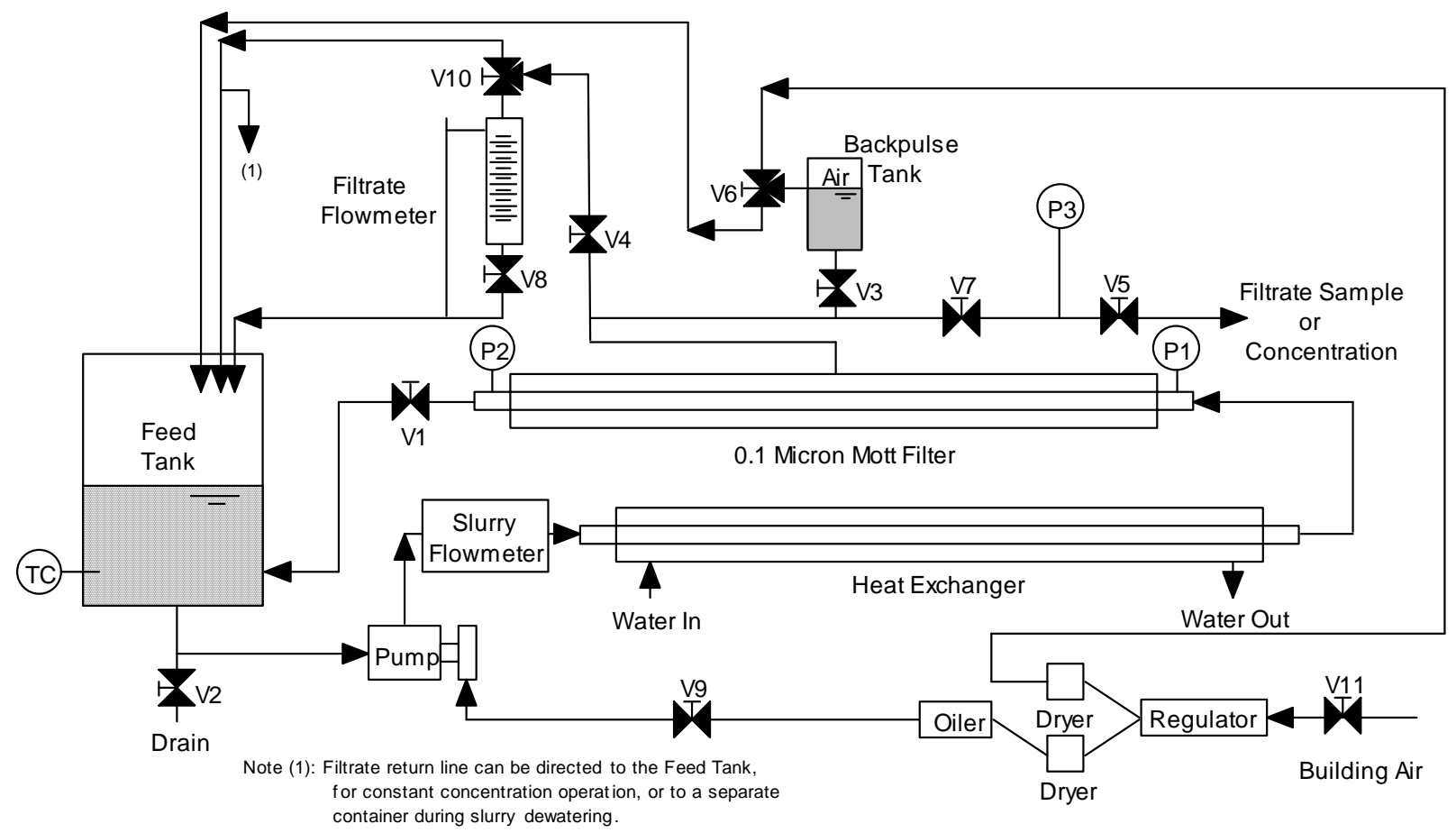

Figure 2-3 Schematic of CUF System

The valves and ports seen in Figure 2-3 are listed in Table 2-3. 
SRNL-STI-2014-00126

Revision 0

Table 2-3 Valve and port descriptions

\begin{tabular}{|l|l|}
\hline V1 & Slurry velocity and pressure control \\
\hline V2 & Feed tank drain \\
\hline V3 & Backpulse actuation and refill \\
\hline V4 & Filtrate flow \\
\hline V5 & Secondary sample and concentration point \\
\hline V6 & 3-Way valve - air pressurize or liquid-fill backpulse tank \\
\hline V7 & Isolate P3 during backpulsing \\
\hline V8 & Filtrate graduated cylinder drain \\
\hline V9 & Allows air to actuate pump motor \\
\hline V10 & 3-Way valve - direct filtrate to graduated cylinder or feed tank \\
\hline V11 & Access to building air \\
\hline P1 & Slurry pressure - upstream port \\
\hline P2 & Slurry pressure - downstream port \\
\hline P3 & Filtrate pressure \\
\hline TC & Type J thermocouple in feed tank \\
\hline
\end{tabular}

The operation of the CUF can be found in the R\&D Direction, found as Appendix B, but the principal operation steps were:

1. Clean CUF with $1 \mathrm{M}$ nitric acid

2. Flush well with deionized and filtered (DIF) water until the $\mathrm{pH}>4$

3. Obtain a clean water filter flux

4. Flush with mild caustic $(0.01 \mathrm{M} \mathrm{NaOH})$ to $\mathrm{pH} \sim 12$

5. Perform test with slurry simulant, concentrating from approximately $1 \mathrm{wt} \%$ to $20 \mathrm{wt} \%$ insoluble solids

6. Flush well with DIF water until the $\mathrm{pH}<8$

7. Clean CUF with $1 \mathrm{M}$ nitric acid

8. Flush well with DIF water until the $\mathrm{pH}>4$

9. Obtain a clean water filter flux

An image of the actual CUF used is shown in Figures 2-4 and 2-5. The close-up focuses on the filter, feed tank, and pump. The second image shows the entire apparatus, including the data acquisition system and water chiller. The crossflow filter tube is identified in Figure 2-4, and the white tube directly beneath it is the heat exchanger. The black line running vertically from the pump motor was the exhaust air line (which needed to be insulated because of the cold temperature created from the expanding air). The blue tubes seen to the right contained the cooling water recirculated through the heat exchanger. 


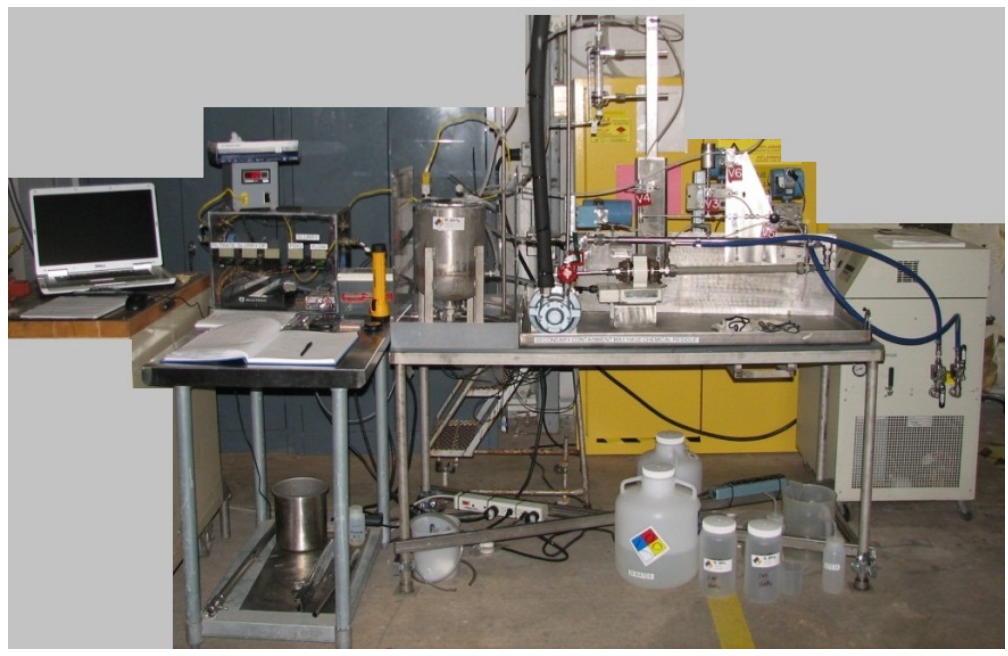

Figure 2-4 Close-up of the Cells Unit Filter System

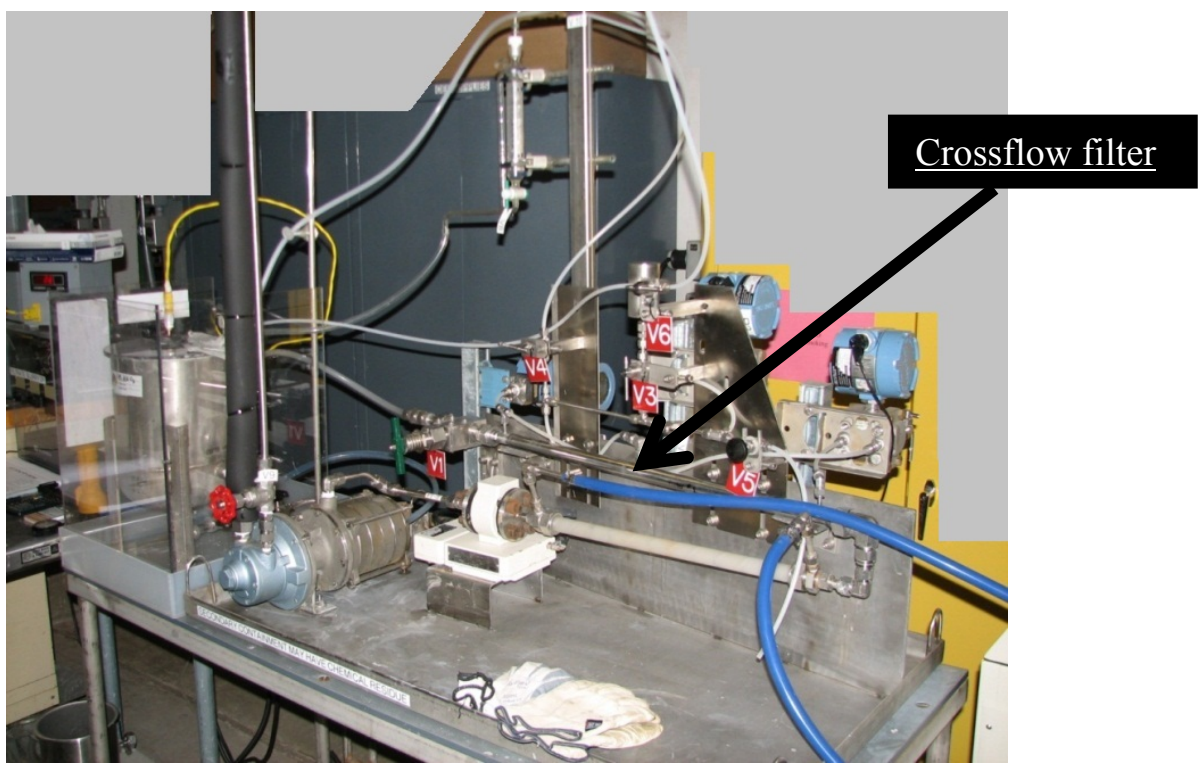

Figure 2-5 Entire CUF Test Equipment

\subsection{Crossflow Filter Testing}

The full test matrix is in Appendix C, along with a detailed summary of the test steps. However, the following describes the highlights of the test which refers to the CUF schematic shown in Figure 2-3.

Because the feed tank could only safely hold about 7 liters the filter test was done in multiple batches to bring the concentration from just under $1 \mathrm{wt} \%$ to close to $20 \mathrm{wt} \%$. (These were the targets and subsequent sample measurements show the slurry was concentrated from 0.5 to 15 wt\%.) During each of the batches both supernatant and slurry samples were taken to measure 
both changing physical and chemical properties of the simulated waste steam. The filter parameters maintained through filtration were a transmembrane pressure of 40 psid, a slurry axial velocity of $11 \mathrm{ft} / \mathrm{s}$, and slurry temperature of $25^{\circ} \mathrm{C} \pm 5^{\circ} \mathrm{C}$. As expected, as the simulant concentration increased, the filter flux decreased. The initial flux was approximately 0.05 $\mathrm{gpm} / \mathrm{ft}^{2}$ at the lowest concentration of insoluble solids and decreased one order of magnitude to $0.005 \mathrm{gpm} / \mathrm{ft}^{2}$ at the highest concentration. However, to improve the filter flux, the filter was periodically scoured, as explained in Appendix C, which temporarily raised the flux by more than $20 \%$.

At the end of the simulant concentration phase of the test, two more follow-on tests were performed to determine the effect of dilution on filtration and the effect of backpulsing on filter flux. To examine the effect of dilution, the filtrate that had been removed from the CUF during the last batch was returned to the feed tank to restore the slurry to the solids concentration that existed at the start of that batch. The initial flow parameters of TMP $=40 \mathrm{psid}$ and $\mathrm{SV}=11 \mathrm{ft} / \mathrm{s}$ were also reestablished. A scouring cycle was performed, after which the filtrate flux was then measured, and found to be approximately $0.004 \mathrm{gpm} / \mathrm{ft}^{2}$. After one hour of continuous recirculation, the flux did not improve and did not return to that observed earlier. It appears that the flow rate observed at the start of this batch $\left(0.007 \mathrm{gpm} / \mathrm{ft}^{2}\right)$ could not be restored, suggesting that either a cake had built up on the filter, or, the simulant had changed character. After the dilution trial, several backpulses were performed in an attempt to restore the flux. Backpulsing steps are detailed in Appendix C. The backpulse was not effective at all, as evidenced by a subsequent filtrate flux of $0.004 \mathrm{gpm} / \mathrm{ft}^{2}$. Additional backpulses at increasing force were performed, with minimal effect. It is possible that the filter cake was fairly well secured onto the filter membrane, or that the shearing due to continuous recirculation during the $\sim 15$ hours of testing and thermal control issues changed the morphology of the solids such that the original flux observed was not restored. In fact after the CUF was drained of simulant and flushed with water, the solids were still quite resilient, as can be seen in Figure 2-6, which shows large patches of grey solids in the bottom of the CUF feed tank.

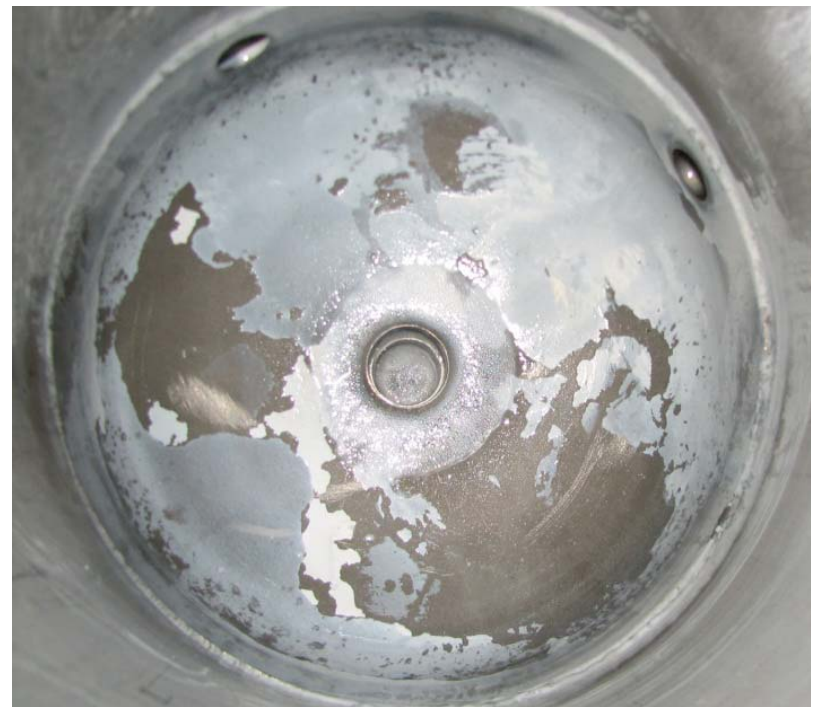

Figure 2-6 Grey solids adhered to bottom of CUF feed tank 
Finally, The CUF was thoroughly cleaned with $1 \mathrm{M} \mathrm{HNO}_{3}$ and then the acid was removed from the system with multiple water flushes until a $\mathrm{pH}>5$ was obtained. A clean water flux was measured, and the filter had returned to $\sim 0.6 \mathrm{gpm} / \mathrm{ft}^{2}$.

\subsection{Cross-flow Filter Chemical Cleaning and Clean Water Flux}

Prior to and after filtering the simulant slurry, the CUF was cleaned with $1 \mathrm{M} \mathrm{HNO}_{3}$. There were two filters on hand for this test and because the filter elements had already been used, acid cleaning was performed before the test. After several days of soaking in nitric acid, followed by soaking in a bath of $0.5 \mathrm{M}$ oxalic acid for 27 hours the first filter was installed in the CUF, rinsed, and checked with water. Those water results are shown in Figure 2-7. There was a substantial improvement of approximately an order of magnitude versus using nitric acid alone. The second filter was also similarly cleaned but its performance was not as good so the first filter was chosen for the test. It was observed that the clean water flux was variable and just before starting the test, it was quite low as seen in Figure 2-7. This variability in the clean water flux is typical with this type of very fine porous media (Daniel et al., 2011) being very sensitive to any trace solids in the system. Further cleaning and flushing was not expected to impact the filter flux that would be obtained when filtering the simulant; therefore, the test commenced.

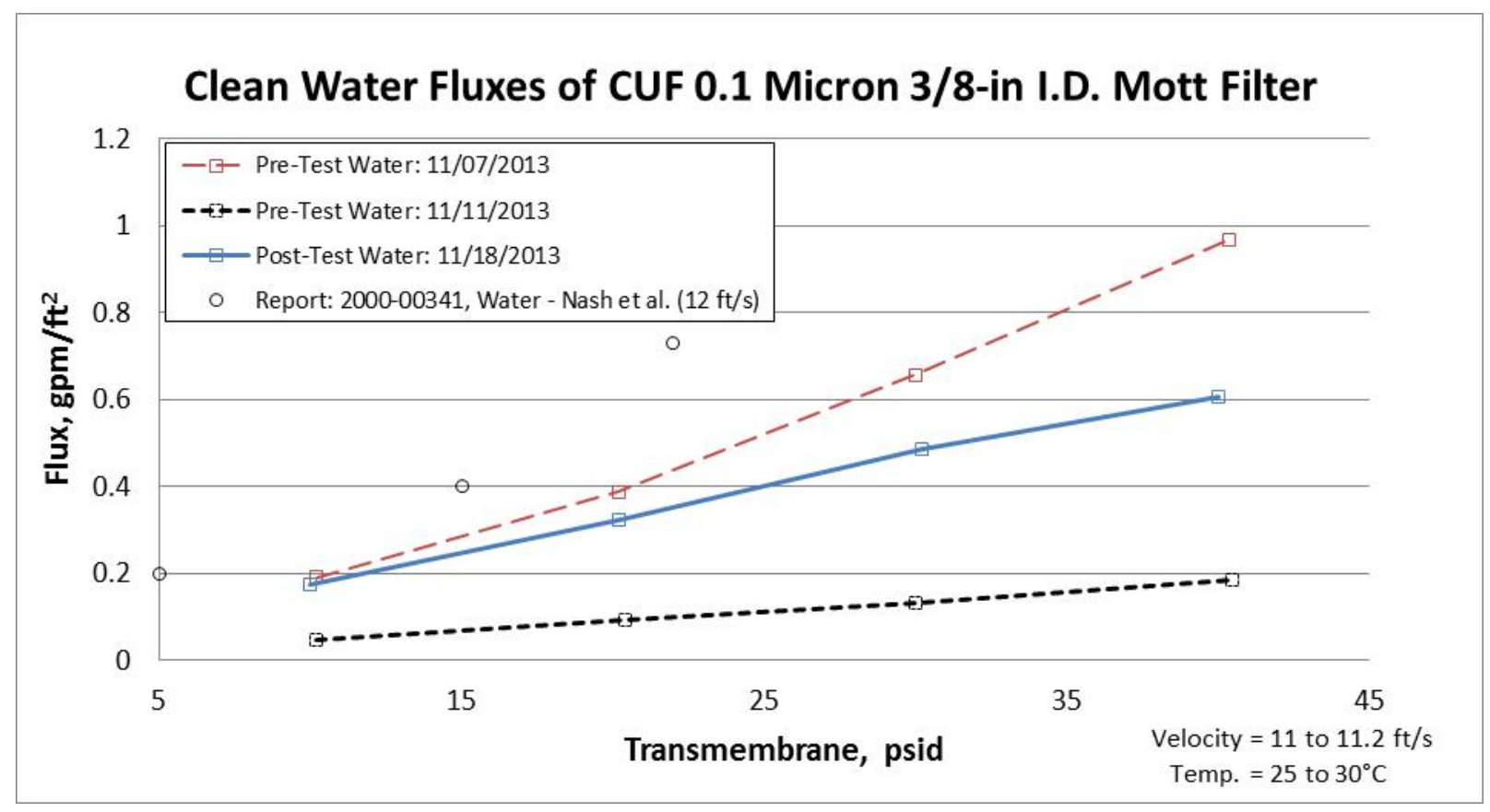

Figure 2-7 Deionized and Filtered Water Flux before and after test 


\subsection{Quality Assurance}

Requirements for performing reviews of technical reports and the extent of review are established in manual E7 2.60. SRNL documents the extent and type of review using the SRNL Technical Report Design Checklist contained in WSRC-IM-2002-00011, Rev. 2. Completion of this work fulfills the requirements of Tasks 4.4 of the Task Technical and Quality Assurance Plan for Technetium Ion Exchange Resin Manufacturing Maturation, SRNL-RP-2012-00708, Revision 2. Laboratory data is contained in (1) Crawford, C. L. "8M Simulant Development for Filterability Testing”, Experiment B9108-00026-10, SRNL E Notebook (Production); Savannah River National Laboratory, Aiken, SC 29808 (2013), and (2) Duignan, M.R., 8 M Na Filterability, SRNL Laboratory notebook SRNL-NB-2013-00075, Savannah River National Laboratory, Aiken, SC 29808 (2013).

\subsection{Results and Discussion}

\subsection{Simulant Preparation Results}

The initial 1-liter $7.75 \mathrm{M}\left[\mathrm{Na}^{+}\right]$analytical simulant that was prepared and the cooled and diluted $5 \mathrm{M}\left[\mathrm{Na}^{+}\right]$simulant derived from the 1-lter $7.75 \mathrm{M}\left[\mathrm{Na}^{+}\right]$analytical sample were both promptly analyzed for weight percent insoluble solids since this physical parameter of the slurry was a critical input to the CUF tasks. The $5 \mathrm{M}\left[\mathrm{Na}^{+}\right]$simulant filtrate was also analyzed in duplicate by ICP-AES and IC-anions to confirm proper batching of the simulants, i.e., to check if final simulant was indeed $5 \mathrm{M}\left[\mathrm{Na}^{+}\right]$, and the results are shown in Table 3-1. These data show that the target concentrations for the $5 \mathrm{M}\left[\mathrm{Na}^{+}\right]$simulant were achieved for the soluble species $\mathrm{Al}, \mathrm{K}, \mathrm{Na}$, $\mathrm{S}$ or sulfate, $\mathrm{Cl}$ nitrite and nitrate. Measured values for $\mathrm{P}$ or phosphate, $\mathrm{Si}, \mathrm{F}$ and oxalate in the filtrate were significantly lower than the total $\mathrm{P}, \mathrm{Si}, \mathrm{F}$ and oxalate in the simulant, indicating precipitation occurred for these species. The calculated $\mathrm{wt} \%$ IS values based on the measured total solids from the slurry and filtrate, using Equation 1, are $1.39 \mathrm{wt} \%$ IS for the $7.75 \mathrm{M}\left[\mathrm{Na}^{+}\right.$] slurry and lower at $0.8 \mathrm{wt} \%$ IS for the cooled and diluted $5 \mathrm{M}\left[\mathrm{Na}^{+}\right]$slurry.

The XRD spectra for the $7.75 \mathrm{M}\left[\mathrm{Na}^{+}\right]$precipitate solids and the $5 \mathrm{M}\left[\mathrm{Na}^{+}\right]$precipitate solids are shown in Figures 3-1 through 3-6. Figure 3-1 shows the XRD spectrum for the $7.75 \mathrm{M}\left[\mathrm{Na}^{+}\right]$ solids contains six different crystalline phases (sodium oxalate, sodium nitrate, sodium carbonate, cancrinite, kogarkoite, and sodium fluorophosphate). It is likely that the soluble salts such as $\mathrm{NaNO}_{3}$ and $\mathrm{Na}_{2} \mathrm{CO}_{3} \mathrm{H}_{2} \mathrm{O}$ are from residual interstitial liquid remaining from the filtration step that dried and then crystallized. Initial matches of the crystalline patterns indicated the presence of cancrinite, or a Ca-containing aluminosilicate $\left(\mathrm{Na}_{6} \mathrm{Ca}_{1.5} \mathrm{Al}_{6} \mathrm{Si}_{6} \mathrm{O}_{24}\left(\mathrm{CO}_{3}\right)_{1.6}\right)$. Since no calciumcontaining salts were used in the simulant formulation, the XRD spectra were reexamined vs. the XRD crystalline species library spectra, and indicated another sodium aluminosilicate $\left(\mathrm{Na}_{6}\left(\mathrm{AlSiO}_{4}\right)_{6}\right.$ as a possible match.

Both an as-filtered and a DI water-washed solids sample were analyzed for the $5 \mathrm{M}\left[\mathrm{Na}^{+}\right]$solids. The XRD spectrum for the $5 \mathrm{M}\left[\mathrm{Na}^{+}\right]$precipitate solids shown in Figure 3-2 contains three crystalline species that were also identified from the $7.75 \mathrm{M} N a$ solids. These species are a sodium, fluoride and phosphate solid (natrophosphate), natroxalate $\left(\mathrm{Na}_{2} \mathrm{C}_{2} \mathrm{O}_{4}\right)$ and a calcium- 
containing cancrinite. Figure 3-3 shows that washing of this $5 \mathrm{M}\left[\mathrm{Na}^{+}\right]$solid with water appears to remove the natrophosphate and the natroxalate, leaving a sodium aluminum silicate crystalline phase.

The XRD spectra comparisons that excluded the presence of Ca-containing species and identified another sodium aluminosilicate $\left(\mathrm{Na}_{6}\left(\mathrm{AlSiO}_{4}\right)_{6}\right.$ as a possible match (in place of the cancrinite) are shown in Figures 3-4 through 3-6.

Table 3-1 Initial Analytical Simulant Results

\begin{tabular}{|c|c|c|c|c|c|}
\hline & Avg. & St.Dev. & Avg. & St.Dev. & Target \\
\hline $\begin{array}{c}\mathbf{5} \mathbf{~ M} \\
\text { Filtrate }\end{array}$ & $\mathbf{m g} / \mathbf{L}$ & $\mathbf{m g} / \mathbf{L}$ & $\mathbf{m o l} / \mathbf{L}$ & $\mathbf{m o l} / \mathbf{L}$ & $\mathbf{m o l} / \mathbf{L}$ \\
\hline & & & & & \\
$\mathrm{Al}$ & 8745 & 35 & 0.324 & 0.001 & 0.340 \\
\hline $\mathrm{K}$ & 1335 & 49 & 0.034 & 0.001 & 0.034 \\
\hline $\mathrm{Na}$ & 115500 & 707 & 5.024 & 0.031 & 5.000 \\
\hline $\mathrm{P}$ & 556.5 & 16 & 0.018 & 0.001 & 0.075 \\
\hline $\mathrm{S}$ & 2330 & 28 & 0.073 & 0.001 & 0.076 \\
\hline $\mathrm{Si}$ & 24.05 & 0.2 & 0.001 & 0.00001 & 0.019 \\
\hline $\mathrm{F}^{-}$ & 1345 & 7 & 0.071 & 0.0004 & 0.124 \\
\hline $\mathrm{Cl}^{-}$ & 1710 & 0 & 0.048 & 0 & 0.045 \\
\hline $\mathrm{NO}_{2}{ }^{-}$ & 31650 & 636 & 0.688 & 0.014 & 0.619 \\
\hline $\mathrm{NO}_{3}{ }^{-}$ & 103500 & 2121 & 1.669 & 0.034 & 1.566 \\
\hline $\mathrm{PO}_{4}{ }^{3-}$ & 1985 & 7 & 0.021 & 0.0001 & 0.076 \\
\hline $\mathrm{SO}_{4}{ }^{2-}$ & 6315 & 7 & 0.066 & 0.0001 & 0.071 \\
\hline $\mathrm{C}_{2} \mathrm{O}_{4}{ }^{2-}$ & 680 & 0 & 0.008 & 0 & 0.023 \\
\hline Simulant & Slurry & Filtrate & Solids & & \\
\hline & Wt.\% TS & Wt.\% TS & Wt.\% IS & & \\
\hline $7.75 \mathrm{M}$ & 38.29 & 36.91 & 1.39 & & \\
\hline $5 \mathrm{M}$ & 27.28 & 26.48 & 0.80 & & \\
\hline Simulant & Slurry & Filtrate & & & \\
\hline & $\begin{array}{c}\text { Density } \\
\text { (g/mL) }\end{array}$ & $\begin{array}{c}\text { Density } \\
\text { (g/mL) }\end{array}$ & & & \\
\hline $7.75 \mathrm{M}$ & 1.348 & 1.333 & & & \\
\hline $5 \mathrm{M}$ & 1.235 & 1.229 & & & \\
\hline & & & & & \\
\hline
\end{tabular}




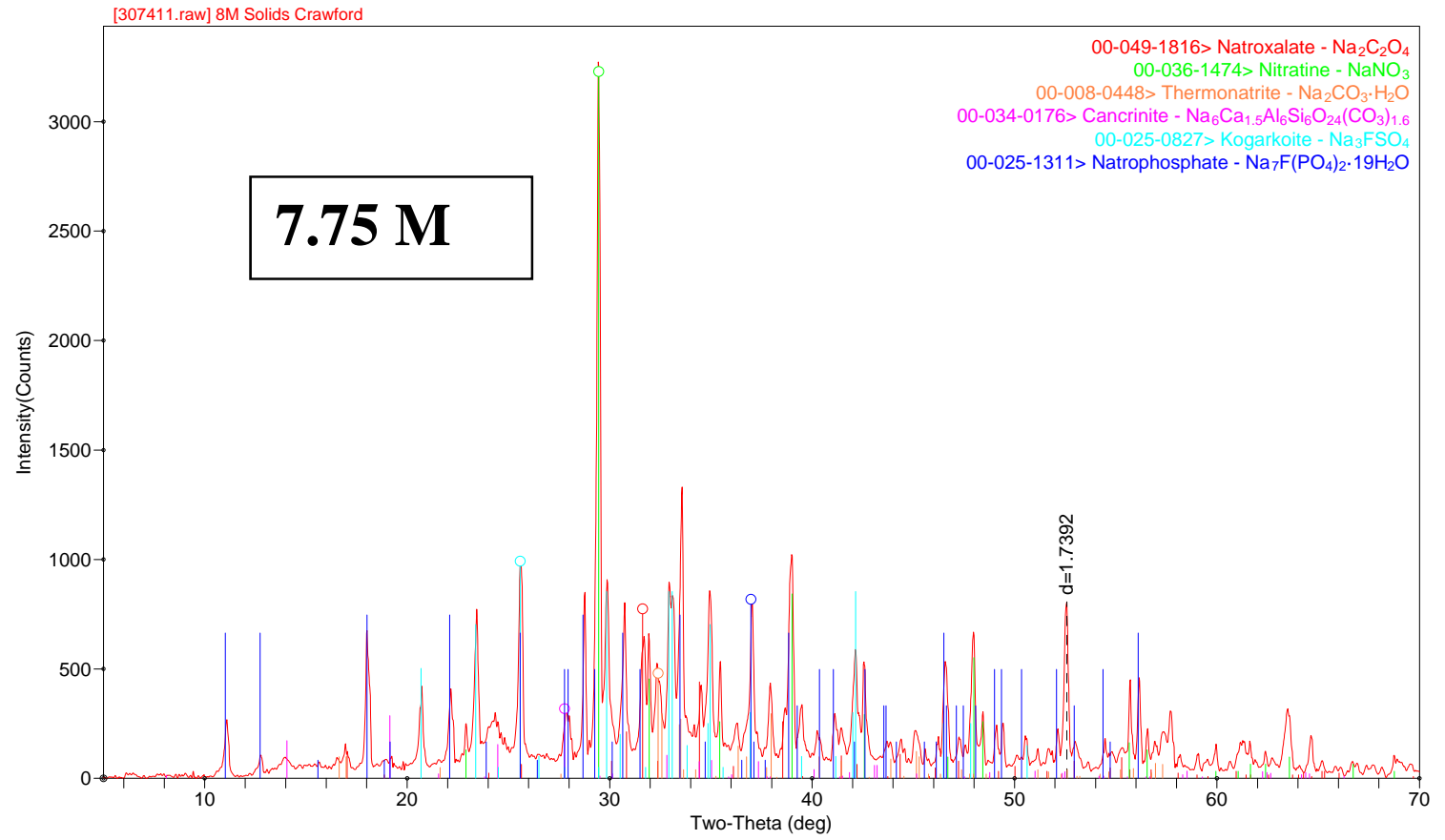

Figure 3-1 XRD Spectra of 7.75 $\mathrm{M}\left[\mathrm{Na}^{+}\right]$Solids

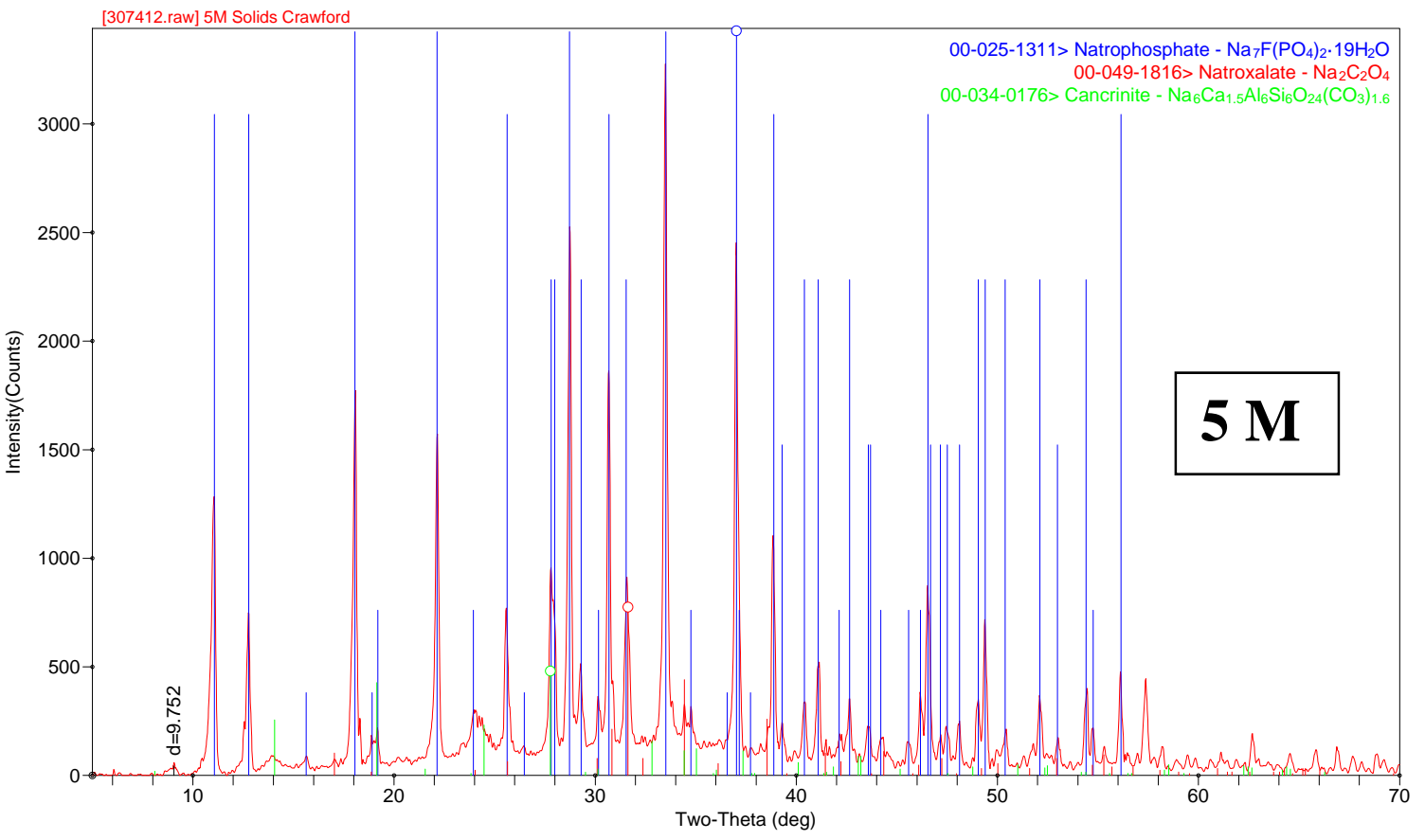

Figure 3-2 XRD Spectra of $5 \mathrm{M}\left[\mathrm{Na}^{+}\right]$Solids 
SRNL-STI-2014-00126

Revision 0

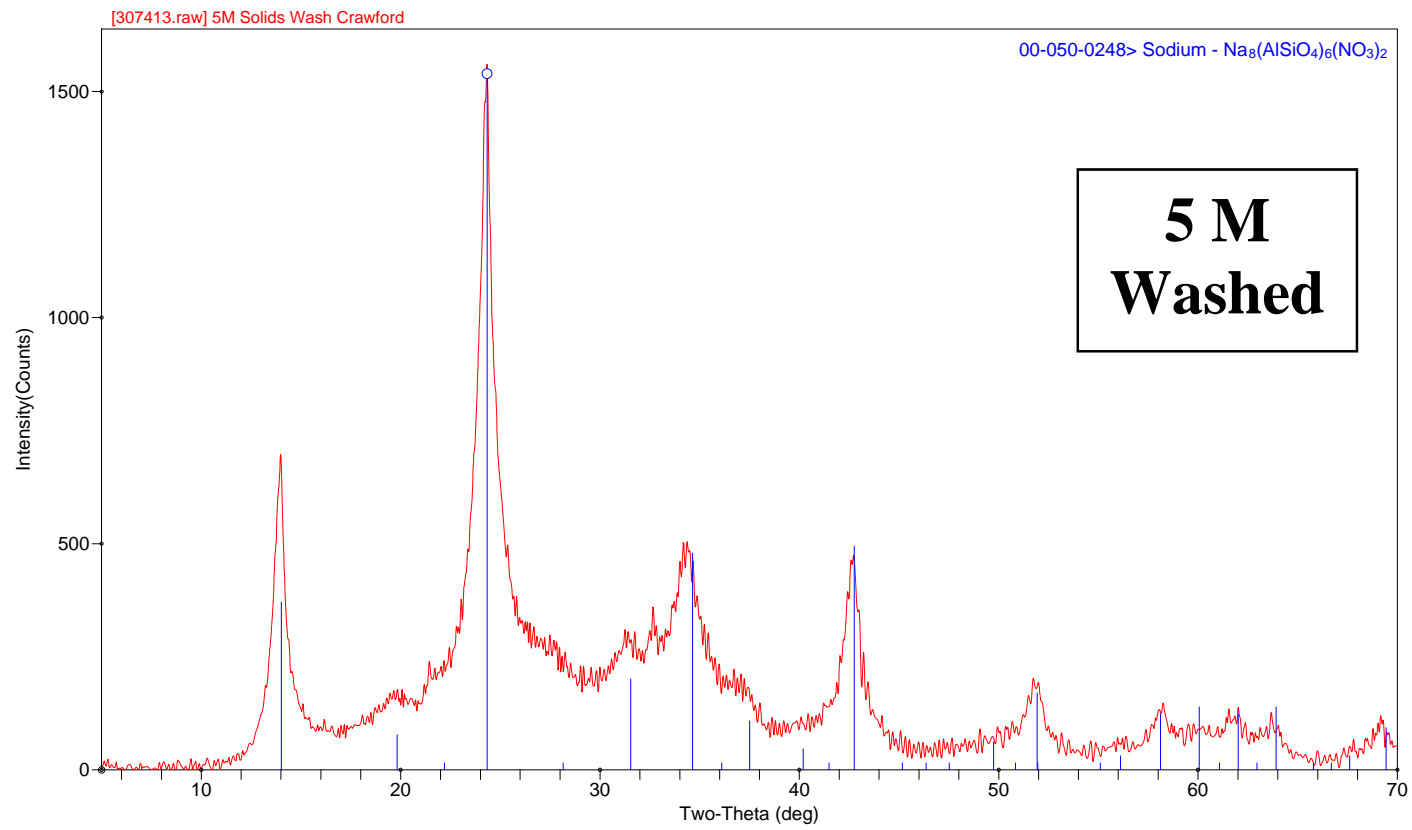

Figure 3-3 XRD Spectra of $5 \mathrm{M}\left[\mathrm{Na}^{+}\right]$Washed Solids

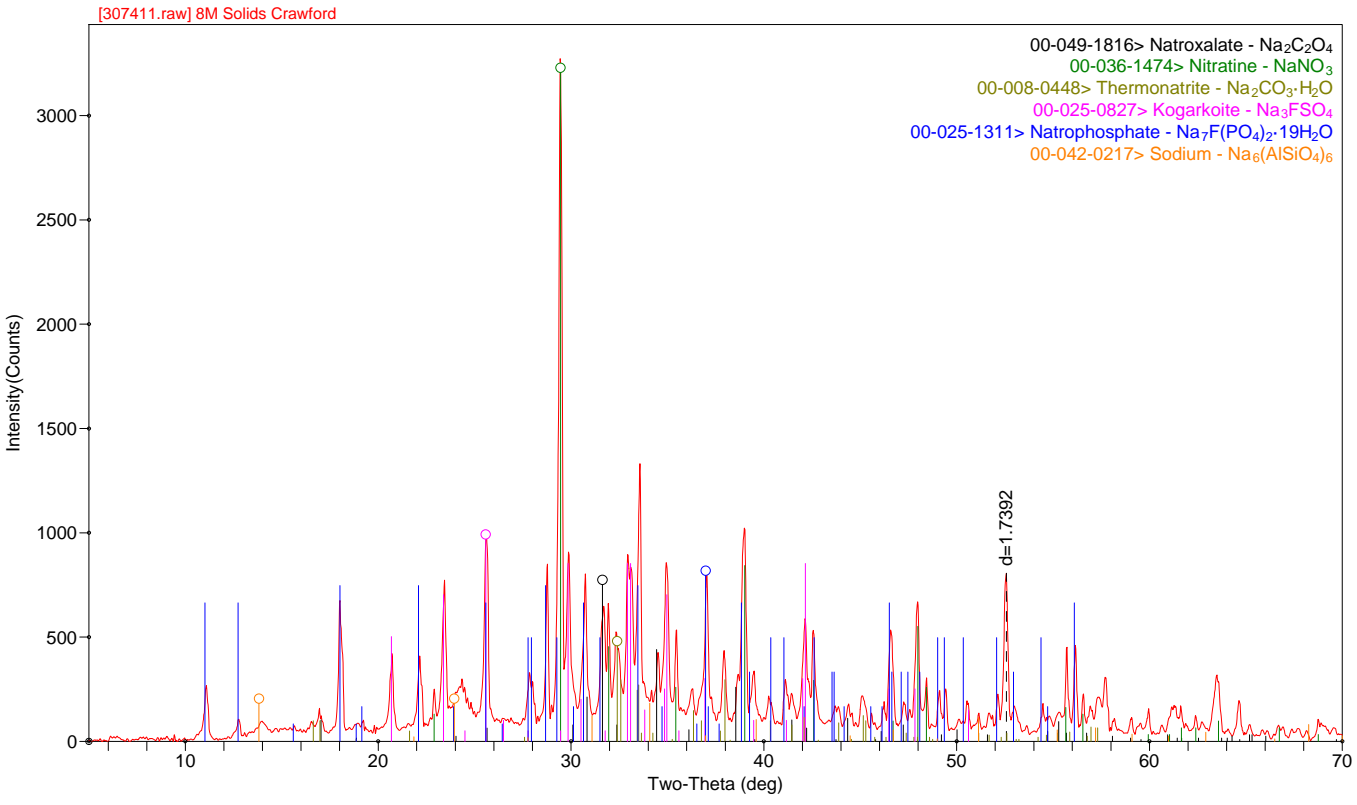

Figure 3-4 XRD Spectra of 7.75 $\mathrm{M}\left[\mathrm{Na}^{+}\right]$Solids Excluding Cancrinite 


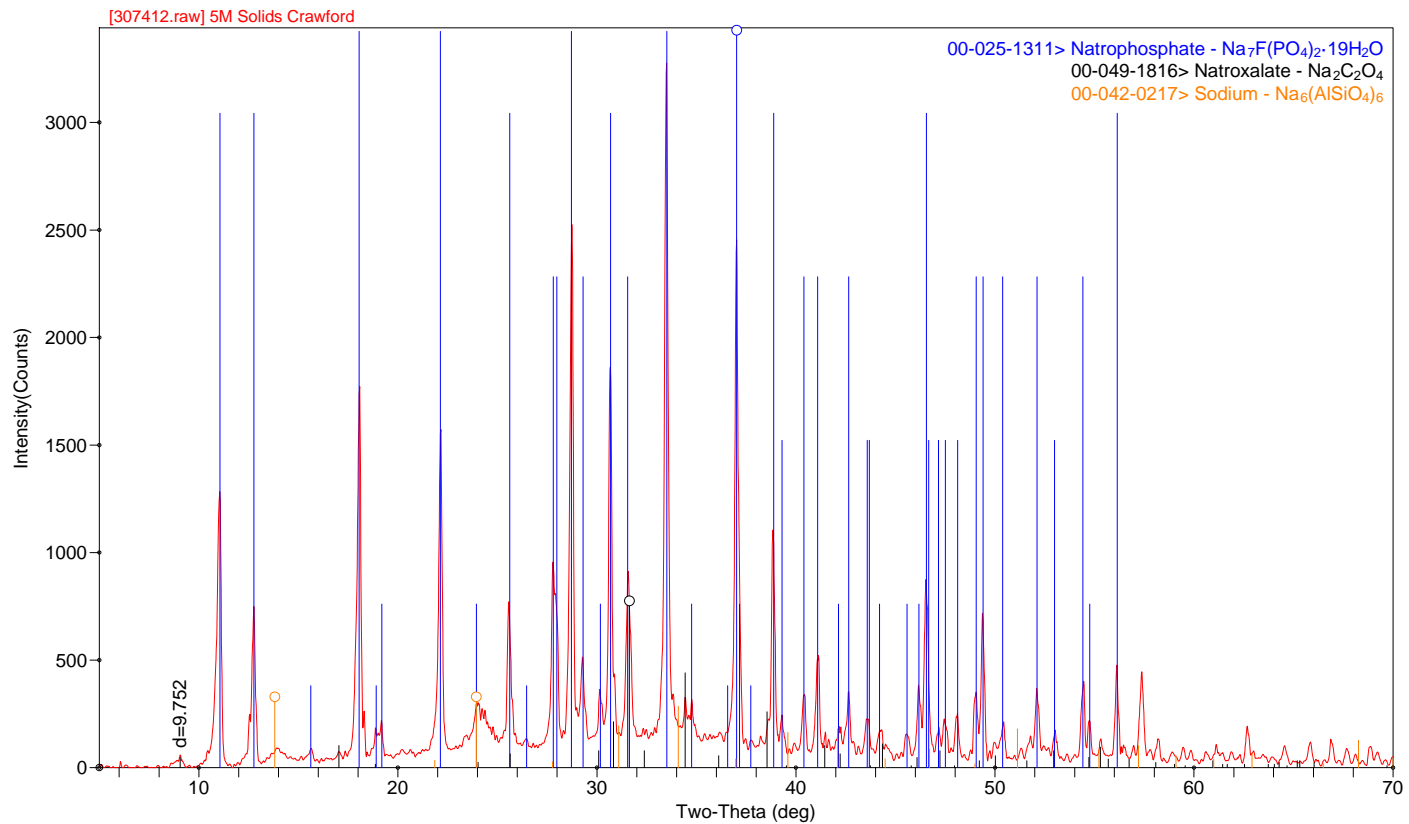

Figure 3-5 XRD Spectra of $5 \mathrm{M}\left[\mathrm{Na}^{+}\right]$Solids

(Crystal pattern fit excludes Cancrinite)

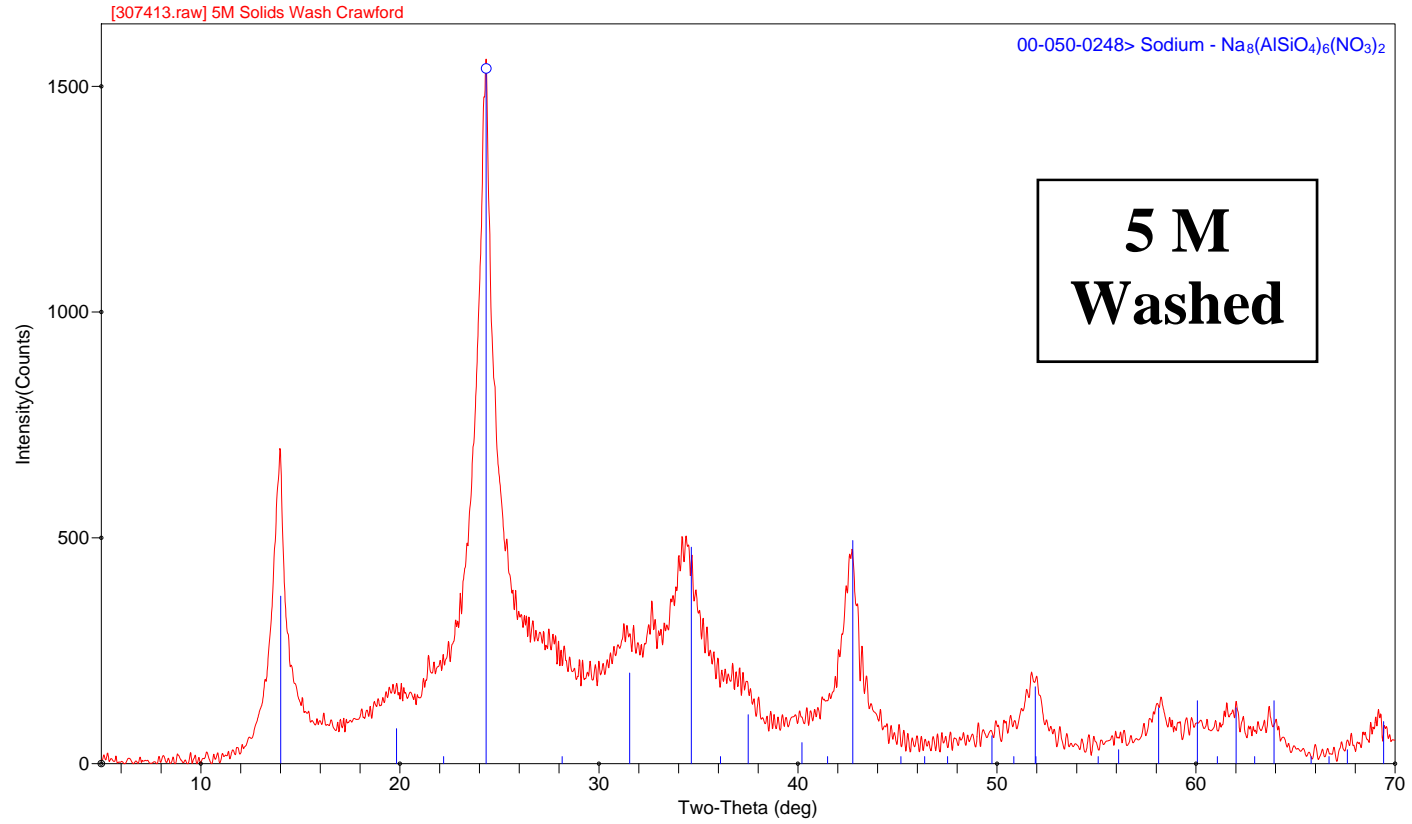

Figure 3-6 XRD Spectra of $5 \mathrm{M}\left[\mathrm{Na}^{+}\right]$Washed Solids

(crystal pattern fit excludes Cancrinite) 


\subsection{Simulant Characterization Results}

\subsection{5 $\mathrm{M}\left[\mathrm{Na}^{+}\right]$Simulant}

The 7.75 $\mathrm{M}\left[\mathrm{Na}^{+}\right]$simulant was analyzed on a total slurry basis and the soluble and insoluble fractions were also separated by filtration with subsequent filtrate and solid precipitate analyses. All analyses were performed in duplicate. The slurry analyses results are shown in Table 3-2 and are compared to the original target concentrations of the various metals and anions. Filtrate analyses are shown in Table 3-3 and are also compared to the target total components in the slurry. Precipitate analyses are shown in Table 3-4 and are reported as weight percent of total solids dissolved. Both tables include results for sodium analysis by both Atomic Absorption (AA-Na) and ICP-ES analytical methods. The free hydroxide content was not measured, but is calculated based on the difference in the sums of the measured values in Table 3-2 for the cations and anions at $2.075 \mathrm{M}$, which compares well with the target of $2.149 \mathrm{M}$.

Table 3-2 7.75 M [Na $\left.{ }^{+}\right]$Slurry Analyses

\begin{tabular}{|c|c|c|c|c|}
\hline & Avg. & St.Dev. & \% RSD & Target \\
\hline $\begin{array}{c}7.75 ~ \mathbf{~} \\
{\left[\mathrm{Na}^{+}\right]} \\
\text {Slurry }\end{array}$ & mol/L & mol/L & & mol/L \\
\hline $\mathrm{Al}$ & 0.534 & 0.0071 & 1.3 & 0.527 \\
\hline $\mathrm{K}$ & 0.054 & 0.0005 & 0.9 & 0.052 \\
\hline $\mathrm{Na}(\mathrm{AA}-\mathrm{Na})$ & 7.49 & 0.1241 & 1.7 & 7.75 \\
\hline $\mathrm{Na}(\mathrm{ICP}-\mathrm{ES})$ & 8.00 & 0.0414 & 0.5 & 7.75 \\
\hline $\mathrm{P}$ & 0.09 & 0.0043 & 4.7 & 0.118 \\
\hline $\mathrm{S}$ & $<0.0005$ & - & - & 0.110 \\
\hline $\mathrm{Si}$ & 0.047 & 0.0006 & 1.2 & 0.0290 \\
\hline $\mathrm{F}^{-}$ & 0.12 & 0.003 & 2.4 & 0.192 \\
\hline $\mathrm{Cl}^{-}$ & 0.072 & 0.0001 & 0.1 & 0.07 \\
\hline $\mathrm{NO}_{2}{ }^{-}$ & 0.98 & 0.02 & 1.8 & 0.960 \\
\hline $\mathrm{NO}_{3}{ }^{-}$ & 2.42 & 0.07 & 2.8 & 2.427 \\
\hline $\mathrm{PO}_{4}{ }^{3-}$ & 0.049 & 0.01 & 12.5 & 0.118 \\
\hline $\mathrm{SO}_{4}{ }^{2-}$ & 0.089 & 0.002 & 2.4 & 0.110 \\
\hline $\mathrm{C}_{2} \mathrm{O}_{4}{ }^{2-}$ & 0.029 & 0.001 & 2.4 & 0.0360 \\
\hline $\mathrm{CO}_{3}{ }^{2-}$ & 0.382 & 0.006 & 1.7 & 0.357 \\
\hline $\mathrm{TOC}^{\mathrm{TC}^{-}}$ & 0.204 & 0.004 & 2.0 & 0.196 \\
\hline & 0.586 & 0.011 & 1.8 & 0.553 \\
\hline
\end{tabular}


Table 3-3 7.75 M [Na ${ }^{+}$Filtrate Analyses*

\begin{tabular}{|c|c|c|c|c|}
\hline & Avg. & St. Dev. & \%RSD & Target \\
\hline $\begin{array}{l}7.75 \mathrm{M}\left[\mathrm{Na}^{+}\right] \\
\text {Filtrate }\end{array}$ & $\mathrm{mol} / \mathrm{L}$ & $\mathrm{mol} / \mathrm{L}$ & & $\mathrm{mol} / \mathrm{L}$ \\
\hline $\mathrm{Al}$ & 0.501 & 0.003 & 0.70 & 0.527 \\
\hline $\mathrm{K}$ & 0.054 & 0.003 & 5.37 & 0.052 \\
\hline $\mathrm{Na}(\mathrm{AA}-\mathrm{Na})$ & 7.202 & 0.235 & 3.26 & 7.75 \\
\hline $\mathrm{Na}$ (ICP-ES) & 7.799 & 0.123 & 1.58 & 7.75 \\
\hline$P$ & 0.031 & 0.012 & 37.86 & 0.118 \\
\hline $\mathrm{S}$ & $<0.0004$ & - & - & 0.110 \\
\hline $\mathrm{Si}$ & 0.002 & 0.000 & 1.94 & 0.0290 \\
\hline $\mathrm{F}^{-}$ & 0.034 & 0.001 & 3.7 & 0.192 \\
\hline $\mathrm{Cl}^{-}$ & 0.074 & 0.000 & 0.5 & 0.07 \\
\hline $\mathrm{NO}_{2}^{-}$ & $1.03 * *$ & 0.334 & 26.4 & 0.960 \\
\hline $\mathrm{NO}_{3}^{-}$ & $2.53 * *$ & 0.810 & 26.1 & 2.427 \\
\hline $\mathrm{PO}_{4}^{3-}$ & 0.010 & 0.000 & 0.5 & 0.118 \\
\hline $\mathrm{SO}_{4}{ }^{2-}$ & 0.031 & 0.001 & 3.6 & 0.110 \\
\hline $\mathrm{C}_{2} \mathrm{O}_{4}{ }^{2-}$ & 0.003 & 0.000 & 6.8 & 0.0360 \\
\hline $\mathrm{CO}_{3}^{2-}$ & 0.411 & 0.007 & 1.7 & 0.357 \\
\hline TOC & 0.153 & 0.002 & 1.5 & 0.196 \\
\hline TC & 0.564 & 0.009 & 1.7 & 0.553 \\
\hline
\end{tabular}

*Filtrate dissolved for ICP-ES analyses; Filtrate not dissolved for IC-anions and TC ** Nitrite and Nitrate values from single analysis 
Table 3-4 7.75 M [Na ${ }^{+}$Precipitate Solids Analyses

\begin{tabular}{|c|c|c|c|}
\hline & Avg. & St. Dev. & \%RSD \\
\hline $\begin{array}{c}\text { 7.75 M }\left[\mathrm{Na}^{+}\right] \\
\text {Solids }\end{array}$ & Wt.\% & Wt. \% & \\
\hline $\mathrm{Al}$ & 3.10 & 0.04 & 1.14 \\
\hline $\mathrm{K}$ & $<0.138$ & - & - \\
\hline $\mathrm{Na}(\mathrm{AA}-\mathrm{Na})$ & 27.73 & 0.45 & 1.63 \\
\hline $\mathrm{Na}(\mathrm{ICP}-\mathrm{ES})$ & 29.05 & 0.21 & 0.73 \\
\hline $\mathrm{P}$ & 1.62 & 0.27 & 16.59 \\
\hline $\mathrm{S}$ & $<0.008$ & - & - \\
\hline $\mathrm{Si}$ & 2.16 & 0.02 & 0.98 \\
\hline $\mathrm{F}^{-}$ & 3.84 & 0.04 & 1.17 \\
\hline $\mathrm{Cl}{ }^{-}$ & $<0.12$ & - & - \\
\hline $\mathrm{NO}_{2}{ }^{-}$ & 1.50 & 0.03 & 2.03 \\
\hline $\mathrm{NO}_{3}{ }^{-}$ & 4.72 & 0.01 & 0.25 \\
\hline $\mathrm{PO}_{4}{ }^{3-}$ & 12.41 & 0.51 & 4.11 \\
\hline $\mathrm{SO}_{4}{ }^{2-}$ & 9.38 & 0.28 & 2.94 \\
\hline $\mathrm{C}_{2} \mathrm{O}_{4}{ }^{2-}$ & 3.26 & 0.11 & 3.36 \\
\hline $\mathrm{CO}_{3}{ }^{2-}$ & 4.84 & 0.57 & 11.85 \\
\hline $\mathrm{TOC}$ & 1.34 & 0.06 & 4.47 \\
\hline $\mathrm{TC}$ & 2.30 & 0.17 & 7.32 \\
\hline
\end{tabular}

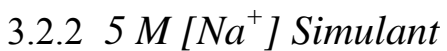

The $5 \mathrm{M}\left[\mathrm{Na}^{+}\right]$simulant slurry was not dissolved and analyzed since the previous $7.75 \mathrm{M}\left[\mathrm{Na}^{+}\right]$ slurry had been analyzed via dissolution and the $5 \mathrm{M}\left[\mathrm{Na}^{+}\right]$slurry resulting from simple water dilution of the more concentrated slurry. The $5 \mathrm{M}\left[\mathrm{Na}^{+}\right]$filtrate was dissolved and analyzed to capture any solids that could have precipitated out of solution after the filtration step. Table 3-5 shows the dissolved $5 \mathrm{M}\left[\mathrm{Na}^{+}\right]$duplicate filtrate analyses that can be compared to the previous 5 $\mathrm{M}\left[\mathrm{Na}^{+}\right]$filtrate analyses shown in Table 3-1. The target components in this table are simply calculated from a $(5 \mathrm{M} / 7.75 \mathrm{M})$ multiplier of the original $7.75 \mathrm{M}\left[\mathrm{Na}^{+}\right]$target concentrations. Comparison of the concentration data in the dissolved filtrate from Table 3-5 to the filtrate analyses previously shown in Table 3-1 indicates no significant precipitation occurs after filtration. Duplicate precipitate analyses for the $5 \mathrm{M}\left[\mathrm{Na}^{+}\right]$slurry filtered solids are shown in Table 3-6 and are reported as weight percent of total solids dissolved. 
Table 3-5 $5 \mathrm{M}\left[\mathrm{Na}^{+}\right]$Filtrate Analyses

\begin{tabular}{|c|c|c|c|c|}
\hline & Avg. & St. Dev. & \%RSD & Target \\
\hline $\begin{array}{c}5 \mathrm{M}\left[\mathrm{Na}^{+}\right] \\
\text {Filtrate }\end{array}$ & $\mathrm{mol} / \mathrm{L}$ & $\mathrm{mol} / \mathrm{L}$ & & mol/L \\
\hline $\mathrm{Al}$ & 0.35 & 0.002 & 0.70 & 0.340 \\
\hline $\mathrm{K}$ & 0.037 & $0 * *$ & - & 0.034 \\
\hline $\mathrm{Na}(\mathrm{AA}-\mathrm{Na})$ & 4.92 & 0.20 & 4.01 & 5.000 \\
\hline $\mathrm{Na}$ & 5.59 & 0.09 & 1.61 & 5.000 \\
\hline $\mathrm{P}$ & 0.031 & 0.012 & 37.856 & 0.076 \\
\hline $\mathrm{S}$ & $<0.0004$ & - & - & 0.071 \\
\hline $\mathrm{Si}$ & 0.0014 & - & - & 0.019 \\
\hline $\mathrm{F}^{-}$ & 0.050 & 0.005 & 10.5 & 0.124 \\
\hline $\mathrm{Cl}^{-}$ & 0.049 & 0.003 & 6.1 & 0.045 \\
\hline $\mathrm{NO}_{2}^{-}$ & 0.70 & 0.04 & 6.1 & 0.619 \\
\hline $\mathrm{NO}_{3}^{-}$ & 1.73 & 0.11 & 6.6 & 1.566 \\
\hline $\mathrm{PO}_{4}{ }^{3-}$ & 0.020 & 0.001 & 4.8 & 0.076 \\
\hline $\mathrm{SO}_{4}^{2-}$ & 0.062 & 0.001 & 1.2 & 0.071 \\
\hline $\mathrm{C}_{2} \mathrm{O}_{4}{ }^{2-}$ & 0.007 & 0.000 & 3.2 & 0.023 \\
\hline $\mathrm{CO}_{3}{ }^{2-}$ & 0.27 & 0 & - & 0.230 \\
\hline TOC & 0.11 & 0 & - & 0.126 \\
\hline TC & 0.38 & 0 & - & 0.357 \\
\hline
\end{tabular}

*Filtrate dissolved for ICP-ES analyses; Filtrate was not dissolved for IC-anions and TC

**Standard Deviation of zero indicates that the duplicate measurement results were identical 
SRNL-STI-2014-00126

Revision 0

Table 3-6 $5 \mathrm{M}\left[\mathrm{Na}^{+}\right]$Precipitate Solids Analyses

\begin{tabular}{|c|c|c|c|}
\hline & Avg. & St. Dev. & $\%$ RSD \\
\hline $\begin{array}{c}\mathrm{M}\left[\mathrm{Na}^{+}\right] \\
\text {Solids } \\
\end{array}$ & Wt.\% & Wt. \% & \\
\hline $\mathrm{Al}$ & 3.84 & 0.21 & 5.52 \\
\hline $\mathrm{K}$ & $<0.135$ & - & - \\
\hline $\mathrm{Na}(\mathrm{AA}-\mathrm{Na})$ & 21.59 & 0.38 & 1.75 \\
\hline $\mathrm{Na}$ & 24.05 & 0.21 & 0.88 \\
\hline $\mathrm{P}$ & 3.75 & 0.02 & 0.57 \\
\hline $\mathrm{S}$ & $<0.008$ & - & - \\
\hline $\mathrm{Si}$ & 3.05 & 0.16 & 5.10 \\
\hline $\mathrm{F}^{-}$ & 1.96 & 0.17 & 8.64 \\
\hline $\mathrm{Cl}^{-}$ & $<0.11$ & - & - \\
\hline $\mathrm{NO}_{2}^{-}$ & 0.88 & 0.03 & 3.66 \\
\hline $\mathrm{NO}_{3}^{-}$ & 2.97 & 0.20 & 6.71 \\
\hline $\mathrm{PO}_{4}{ }^{3-}$ & 17.91 & 1.41 & 7.85 \\
\hline $\mathrm{SO}_{4}{ }^{2-}$ & 0.59 & 0.05 & 7.92 \\
\hline $\mathrm{C}_{2} \mathrm{O}_{4}{ }^{2-}$ & 2.97 & 0.04 & 1.28 \\
\hline $\mathrm{CO}_{3}{ }^{2-}$ & 3.87 & 0.58 & 14.87 \\
\hline TOC & 1.35 & 0.11 & 8.45 \\
\hline $\mathrm{TC}$ & 2.12 & 0.22 & 10.56 \\
\hline
\end{tabular}

\subsection{Simulant Stability Results}

The stability of the original $5 \mathrm{M}\left[\mathrm{Na}^{+}\right]$slurry was investigated via measurement of the filtrate soluble components and the total solids of the slurry and filtrate held at $25{ }^{\circ} \mathrm{C}$. These data are shown in Table 3-7 below. The initial $5 \mathrm{M}\left[\mathrm{Na}^{+}\right]$filtrate was analyzed in duplicate and all others were single sample analyses. Initial analyses occurred in on October 28, 2013 and the final 'Age 3' sample was analyzed on January 13, 2014. All four of these data sets (Initial (10/28/13), Age 1 (7 days; 11/4/13), Age 2 (37 days; 12/4/13) and Age 3 (77 days; 1/13/14)) were averaged and the resulting data are shown as the last three data columns in Table 3-7. The soluble elements A1, $\mathrm{K}, \mathrm{Na}, \mathrm{P}$ and $\mathrm{S}$ were all consistent throughout the samples indicating no significant change in their filtrate concentration. Measured soluble Si appears to drop below the ICP-ES method detection limit of $14.2 \mathrm{mg} / \mathrm{L}$ for the latter two samples which suggest the relatively low amount of soluble Si precipitated from solution with aging. Total solids measurements on both the slurry and the filtrate were performed which also allowed calculation of the weight percent insoluble solids. These data suggest that the $5 \mathrm{M}\left[\mathrm{Na}^{+}\right]$slurry was stable over the ten week period with the slurry total solids averaging $27.69 \%+/-0.28 \%$ and the filtrate total solids averaging $26.90 \%+/-$ $0.36 \%$. 
Table 3-7 Stability Data for $5 \mathrm{M}\left[\mathrm{Na}^{+}\right]$Slurry

\begin{tabular}{|c|c|c|c|c|c|c|c|}
\hline & $\begin{array}{c}\text { Initial } \\
\text { Avg. }\end{array}$ & $\begin{array}{c}\text { Age } 1 \\
\text { (7 days) }\end{array}$ & $\begin{array}{c}\text { Age } 2 \\
\text { (37 days) }\end{array}$ & $\begin{array}{c}\text { Age } 3 \\
\text { (77 days) }\end{array}$ & All Avg. & St. Dev. & \%RSD \\
\hline $\begin{array}{c}5 \mathrm{M} \\
{\left[\mathrm{Na}^{+}\right]} \\
\text {Filtrate }\end{array}$ & $\mathrm{mg} / \mathrm{L}$ & $\mathrm{mg} / \mathrm{L}$ & mg/L & mg/L & mg/L & mg/L & \\
\hline $\mathrm{Al}$ & 8745 & 9130 & 8620 & 9260 & 8900 & 278 & 3.1 \\
\hline $\mathrm{K}$ & 1335 & 1550 & 1470 & 1570 & 1452 & 116 & 8.0 \\
\hline $\mathrm{Na}$ & 115500 & 128000 & 117000 & 124000 & 120000 & 5701 & 4.8 \\
\hline $\mathrm{P}$ & 557 & 458 & 473 & 463 & 501.4 & 51 & 10.2 \\
\hline $\mathrm{S}$ & 2330 & 2560 & 2550 & 2790 & 2512 & 192 & 7.7 \\
\hline $\mathrm{Si}$ & 24.1 & 21.5 & $<14.2$ & $<14.2$ & NA & NA & NA \\
\hline & $\begin{array}{c}\text { Initial } \\
\text { wt } \%\end{array}$ & $\begin{array}{l}\text { Age } 1 \\
\text { wt } \%\end{array}$ & Age 2 & Age 3 & All Avg. & St. Dev. & \%RSD \\
\hline $\begin{array}{c}5 \mathrm{M} \\
{\left[\mathrm{Na}^{+}\right]} \\
\text {Slurry } \\
\left(\mathrm{W}_{\mathrm{ts}}\right) \\
\end{array}$ & $27.28 \%$ & $27.76 \%$ & $27.94 \%$ & $27.78 \%$ & $27.69 \%$ & $0.28 \%$ & 1.0 \\
\hline $\begin{array}{c}5 \mathrm{M} \\
{\left[\mathrm{Na}^{+}\right]} \\
\text {Filtrate } \\
\left(\mathrm{W}_{\mathrm{ds}}\right) \\
\end{array}$ & $26.48 \%$ & $26.73 \%$ & $27.16 \%$ & $27.23 \%$ & $26.90 \%$ & $0.36 \%$ & 1.3 \\
\hline $\mathrm{W}_{\text {is }}$ & $0.80 \%$ & $1.03 \%$ & $0.78 \%$ & $0.55 \%$ & $0.79 \%$ & $0.20 \%$ & 24.8 \\
\hline
\end{tabular}

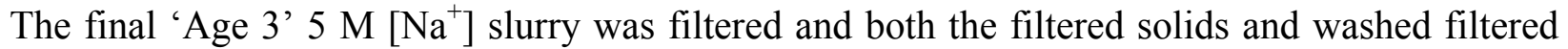

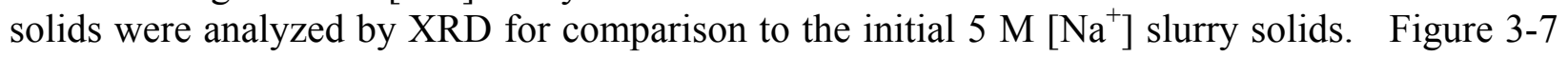
shows the Age 3 solids that contain three of the same crystalline species identified in the initial solids (natrophosphate, natroxalate and sodium aluminum silicate). In addition three other sodium salts are identified as sodium nitrite, sodium nitrate, and a hydrated sodium phosphate. As noted above, it is likely that these soluble sodium salts are from residual interstitial liquid remaining from the filtration step that dried and crystallized. Figure 3-8 shows that washing of the 'Age 3' $5 \mathrm{M}\left[\mathrm{Na}^{+}\right]$solids results in complete dissolution of all the crystalline species except for a sodium aluminosilicate species. Similar observations were made for washing of the initial $5 \mathrm{M}\left[\mathrm{Na}^{+}\right]$solids. 


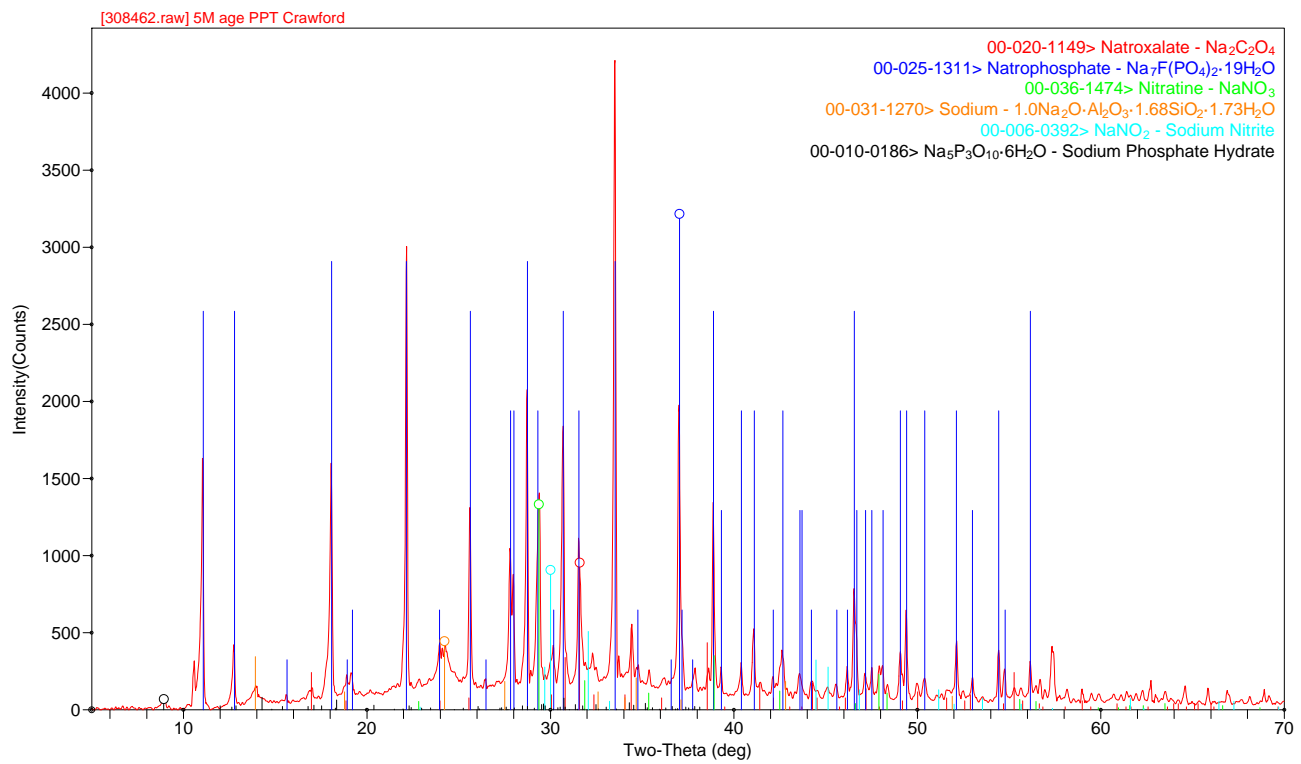

Figure 3-7 XRD Spectra of $5 \mathrm{M}\left[\mathrm{Na}^{+}\right]$Age 3 Solids

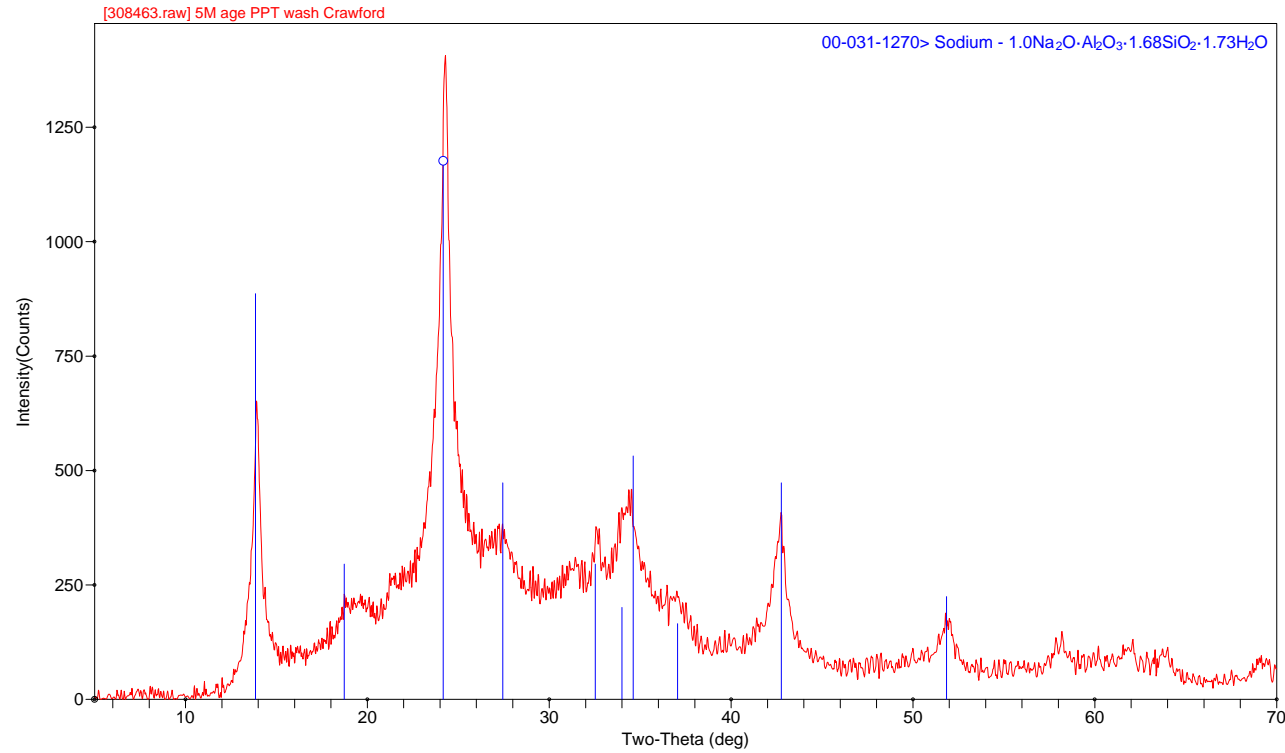

Figure 3-8 XRD Spectra of $5 \mathrm{M}\left[\mathrm{Na}^{+}\right]$Age 3 Solids - Washed

Particle size distribution results for the initial 1 Liter $5 \mathrm{M}$ Na slurry and both a pre and post CUF slurry from the start of the $2^{\text {nd }}$ day of filtration were obtained to investigate the particle size distributions for these slurries. Figure 3-9 shows the PSD on a volume distribution (upper trace) and a number distribution (lower trace). These data indicate that the particles in the initial slurry are distributed in a bi-modal distribution, centered on a lower $\sim 7 \mu \mathrm{m}(16 \%)$ and upper $\sim 100 \mu \mathrm{m}$ 
(84\%) diameter. The MV for this slurry indicates that the 'center of gravity' is located around $86.3 \mu \mathrm{m}$ and the average particle size contributing to the population, $\mathrm{MN}$, is $3.2 \mu \mathrm{m}$.

Figure 3-10 shows the PSD data for the larger scale $5 \mathrm{M} \mathrm{Na}$ slurry prepared for the CUF on a volume distribution (upper trace) and a number distribution (lower trace). These data indicate that the particles in the initial slurry are distributed in a bi-modal distribution centered on a lower $\sim 6 \mu \mathrm{m}(42 \%)$ and upper $\sim 79 \mu \mathrm{m}(58 \%)$ diameter. The MV for this slurry indicates that the 'center of gravity' is located around $56 \mu \mathrm{m}$ and the average particle size contributing to the population, $\mathrm{MN}$, is $1.4 \mu \mathrm{m}$. Comparison of the larger scale slurry PSD from Figure 3-10 to the PSD for the smaller scale 1 Liter slurry in Figure 3-9 shows that the larger scale slurry contains more of the smaller diameter particles centered around $\sim 6.5 \mu \mathrm{m}$.

Figure 3-11 shows the PSD data for the larger scale $5 \mathrm{M}$ Na slurry prepared for the CUF after the slurry had been processed and concentrated through the CUF on a volume distribution (upper trace) and a number distribution (lower trace). These data indicate that the particles in the postCUF slurry are distributed in a distribution centered on a $\sim 7.5 \mu \mathrm{m}$ diameter. The MV for this slurry indicates that the 'center of gravity' is located around $13 \mu \mathrm{m}$ and the average particle size contributing to the population, $\mathrm{MN}$, is $0.89 \mu \mathrm{m}$. Comparing to data in Figure 3-10, these data indicate that the slurry particle sizes were significantly reduced due to processing through the CUF.

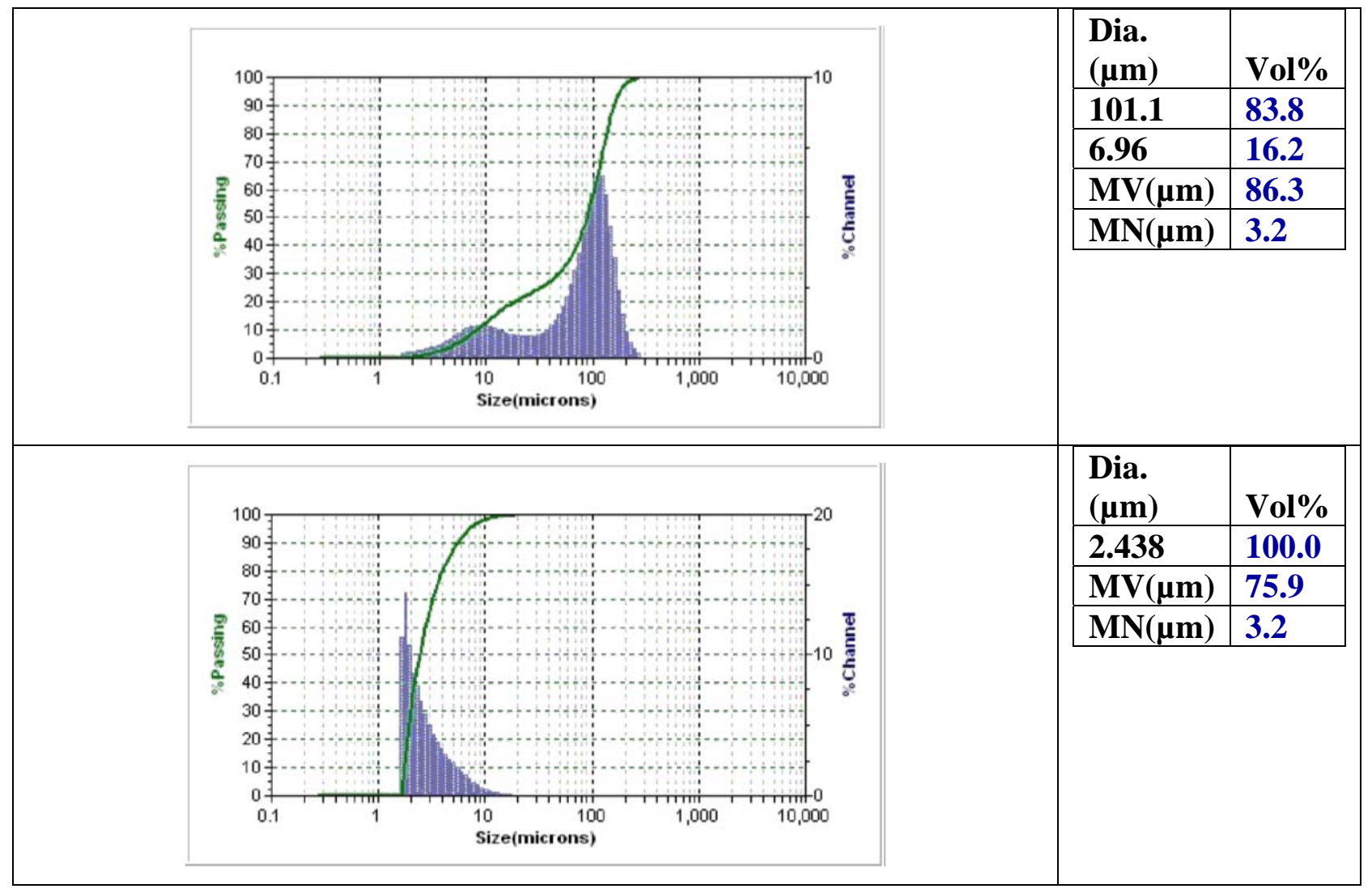

Figure 3-9 PSD of Initial 1 Liter $5 \mathrm{M}\left[\mathrm{Na}^{+}\right]$Slurry 
SRNL-STI-2014-00126

Revision 0

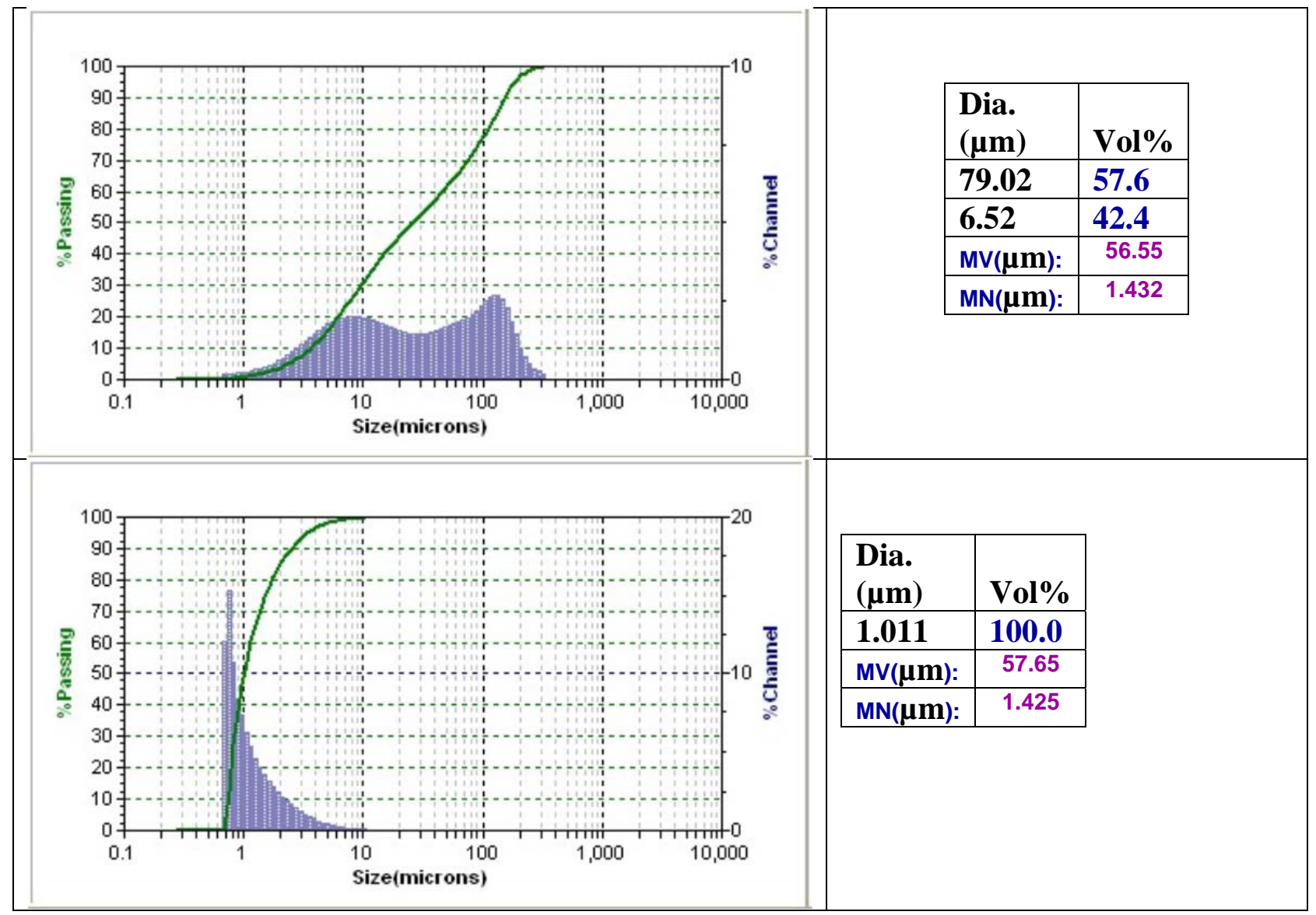

Figure 3-10 PSD of Slurry Before CUF 


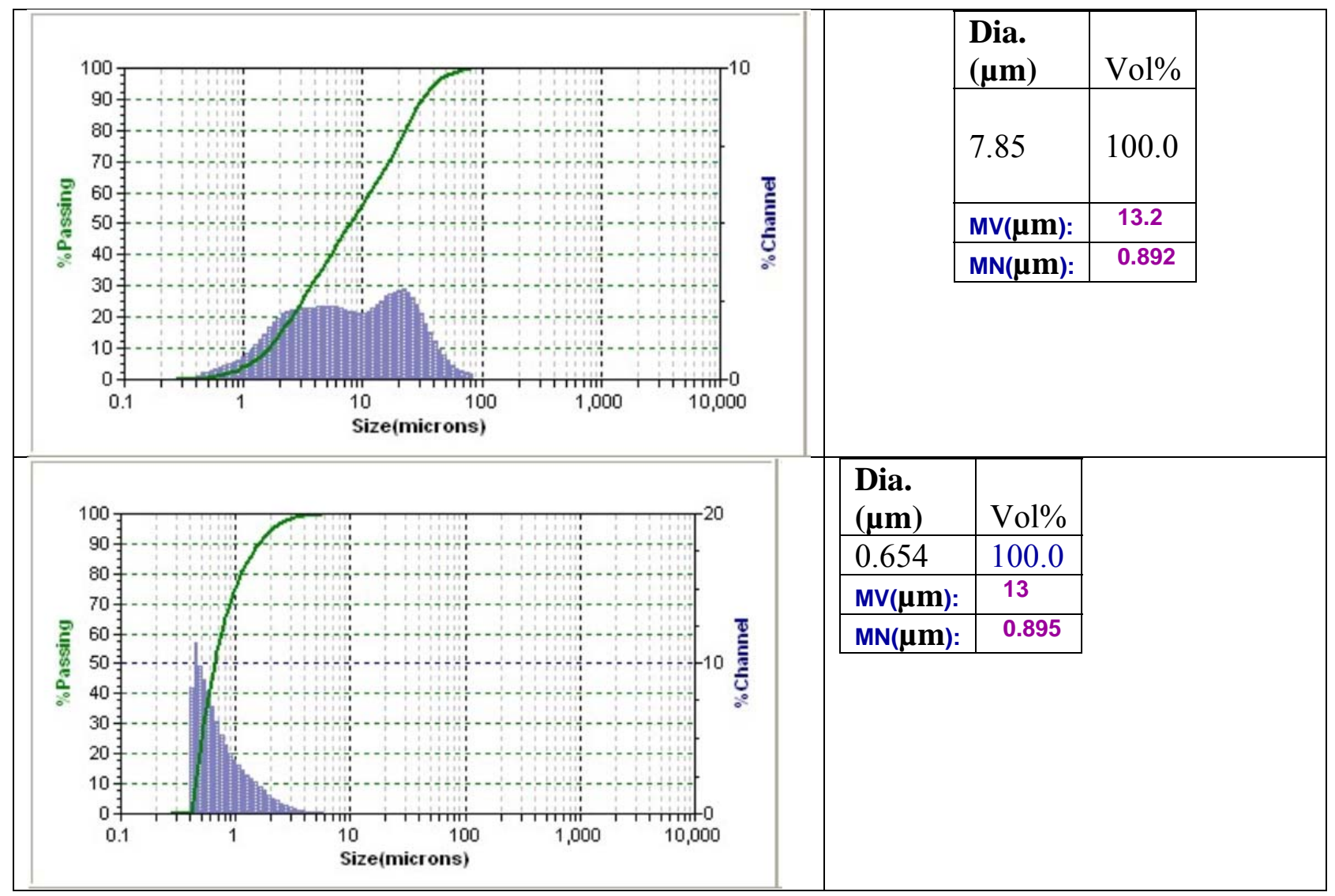

Figure 3-11 PSD of Slurry After CUF Processing

\subsection{Cross-flow filtration Results}

Over an approximate 2-week period, existing CUF equipment was assembled, cleaned, and calibrated. The filter tube dimensions were, 0.375-in insider diameter, of a Mott grade 0.1 media. New filter tubes always perform much better than those in long-term service, so starting with used tubes is a conservative demonstration of filter performance more representative of what can be expected in long-term operation. Chemical cleaning on the available filter equipment was judged sufficient to resemble realistic long-term operational performance. Simulant testing lasted over three days using a total volume of approximately 45 liters, concentrated down to approximately 2 liters in order to increase the insoluble solids (IS) concentration from a planned $0.8 \mathrm{wt} \%$ to $20 \mathrm{wt} \%$. However, because the capacity of the CUF feed tank is only approximately 8 liters, and because filtering 40 liters in the CUF was expected to take a long time, the concentration process was supplemented with a settle-decant-filter method. The first 5 liters of $0.8 \mathrm{wt} \%$ simulant was initially added to the CUF to begin filtering. The remaining batch of 35 liters was made in a 15-liter batch and a separate 5-liter plus 15-liter combination batch at 0.8 $\mathrm{wt} \%$, and then each of these was allowed to settle, decanted, and the decanted liquid was poured into dead-end filters to capture the non-settling solids. Figure 3-12 shows the bank of $0.45 \mu \mathrm{m}$ 
dead-end filters employed. The first 15-liter batch was concentrated to approximately 5 liters of $3.2 \mathrm{wt} \%$ IS and then added to the CUF feed tank when the CUF simulant reached the same IS loading. Then the second batch consisting of both a 5-liter and a 15-liter sample was concentrated to approximately 2.25 liters of $7 \mathrm{wt} \%$ IS and added to the CUF feed tank when the CUF simulant reached the same IS loading. The method reduced the actual CUF filtering time from an estimated 100 hours to 16 hours. Although the decanted supernatant of the batches of simulant contained only a small amount of solids, some did get captured on the dead-end filters. Those damp solids were carefully scraped off the filters and added to the concentrated simulant slurry before adding the simulant slurry to the CUF to ensure that the full range of insoluble solids were processed in the CUF. All filtrate from this settle-decant-filter method was collected as residual material and not further used in the CUF testing.

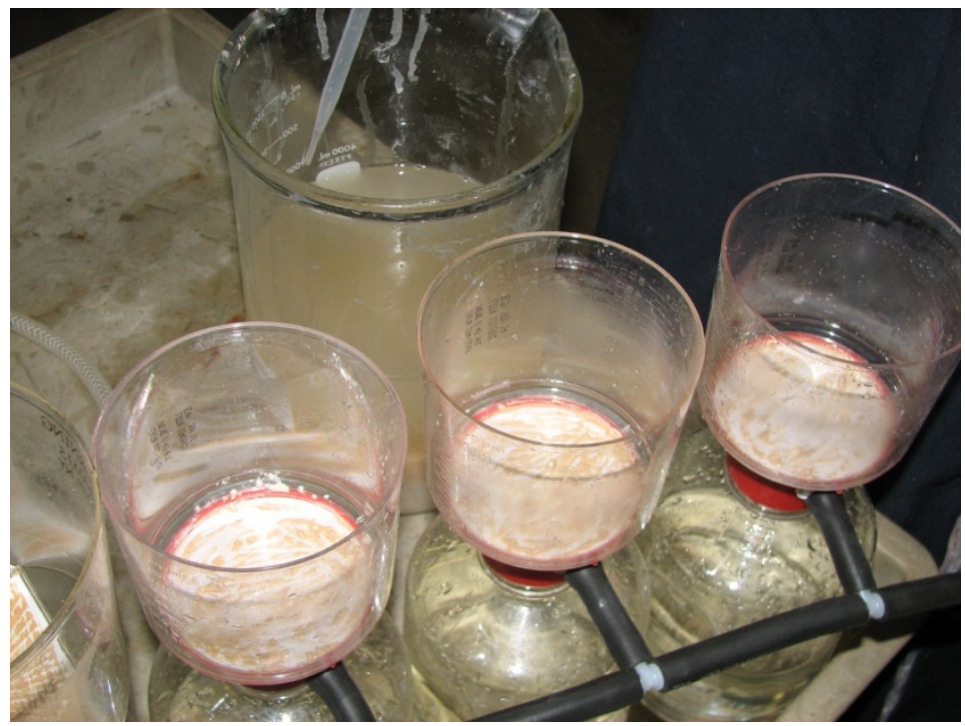

Figure 3-12 Dead-end filters used, 0.45 $\mu \mathrm{m}$ pore, to pre-concentrate simulant

At the start of crossflow operation, the filter was smooth and steady. The TMP and the SV were recorded every minute and are illustrated in Figure 3-12. For approximately 13 of the 15 hours of the test, the $\mathrm{SV}$ was held to $10.7 \mathrm{ft} / \mathrm{s} \pm 0.6 \mathrm{ft} / \mathrm{s}$ (1 standard deviation). Actual operating hours during the first two days lasted approximately 6.5 hours each, but only lasted approximately 2 hours on the final day due to the reduced simulant volume and filter flux of $0.005 \mathrm{gpm} / \mathrm{ft}^{2}$. 


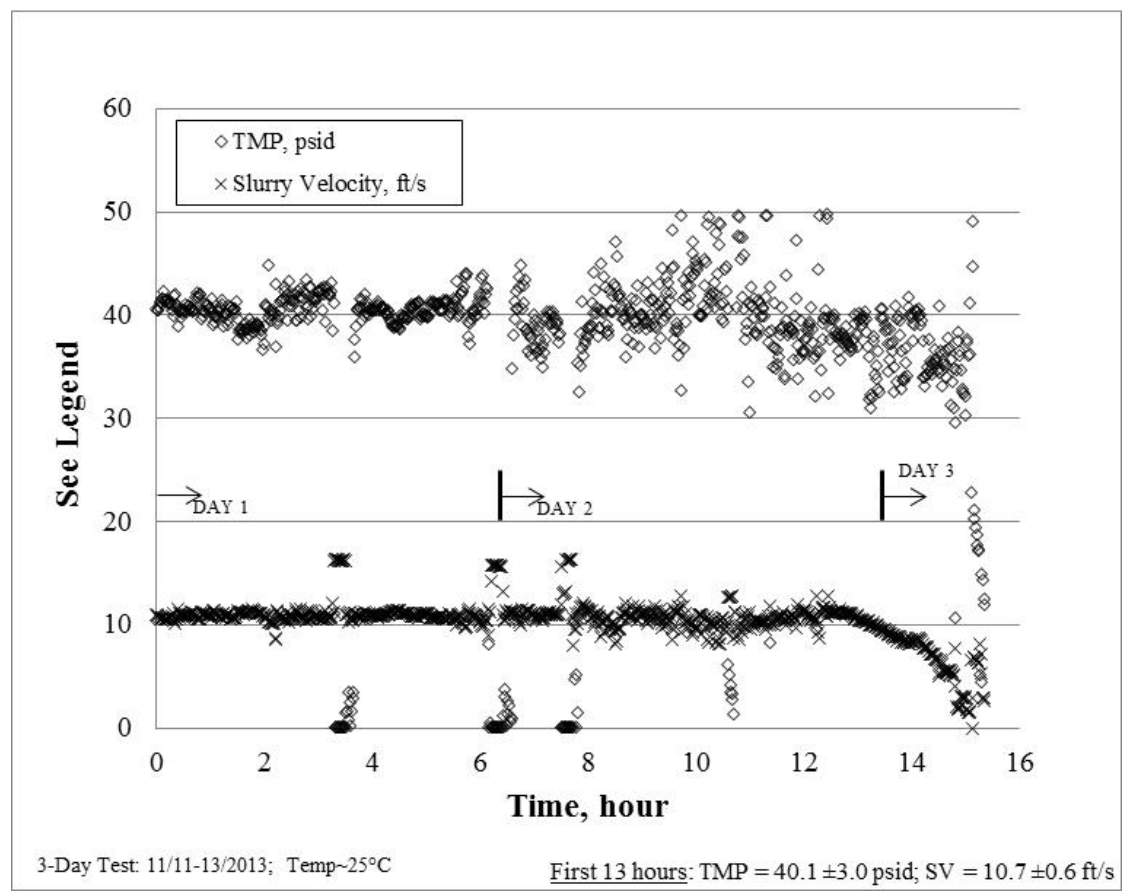

Figure 3-13 TMP and Slurry Axial Velocity during test - downtimes excluded

Just before ending the test on the third day, the AV and TMP were very difficult to maintain and began to drop precipitously. This drop was believed to have occurred because the IS had reached approximately $15 \mathrm{wt} \%$, which caused the solids to successively build up and surge out of the slurry control valve, VI, see Figure 2-3.

As seen in Figure3-13, for the first day of testing, i.e., $\sim 6.5$ hours, both the SV and TMP were steady, with a SV of approximately $11 \mathrm{ft} / \mathrm{s}$ during which the IS increased from 0.8 to an estimated $6.5 \mathrm{wt} \%$. During the second day, the IS concentration started at nearly $7 \mathrm{wt} \%$ and increased to an estimated $15 \mathrm{wt} \%$. During this second $\sim 6.5$ hours of operation, the SV was nearly as steady as the first day, with slightly more fluctuation. However, the fluctuation of the TMP increased considerably, which was believed to be caused by the increased solids concentration affecting the downstream slurry valve, V1. Evidently, with increased solids loading, some of those solids may have begun to periodically block the opening of the valve V1 as the slurry exited the filter. The pressure port for this down-steam location is just upstream of valve V1; therefore, these pressure pulses were measured readily at the P2 transducer, Figure 2-3. At the start of the second day of operation, before the CUF was started, and before the second batch of simulant was added the slurry exhibited a minimal volume but sustained foamy appearance. Figure 3-14(a) shows the simulant in the CUF feed tank as the start of the second day of testing and Figure 3-14(b) is a close up of the bubble structure and interstitial floating solids before mixing began. 


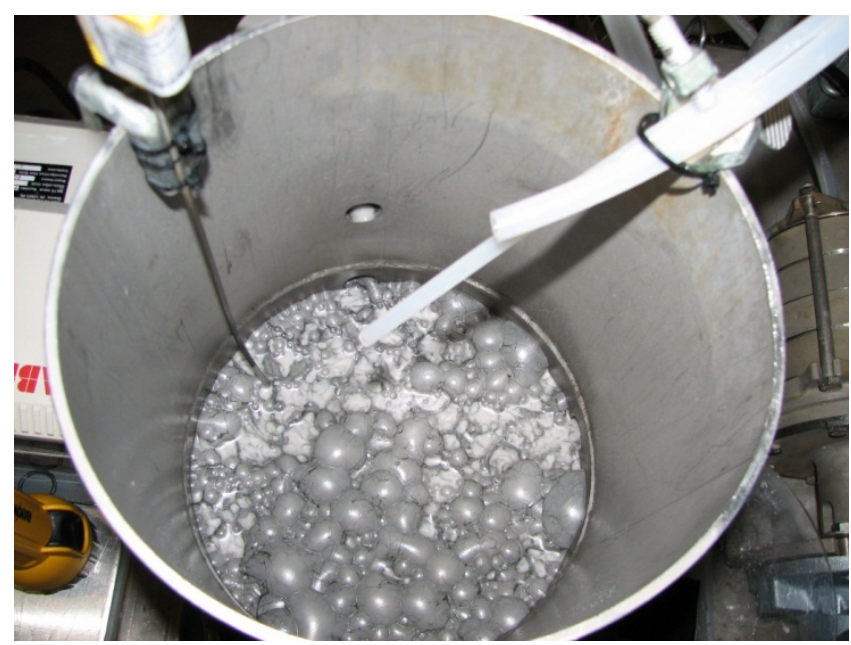

(a)

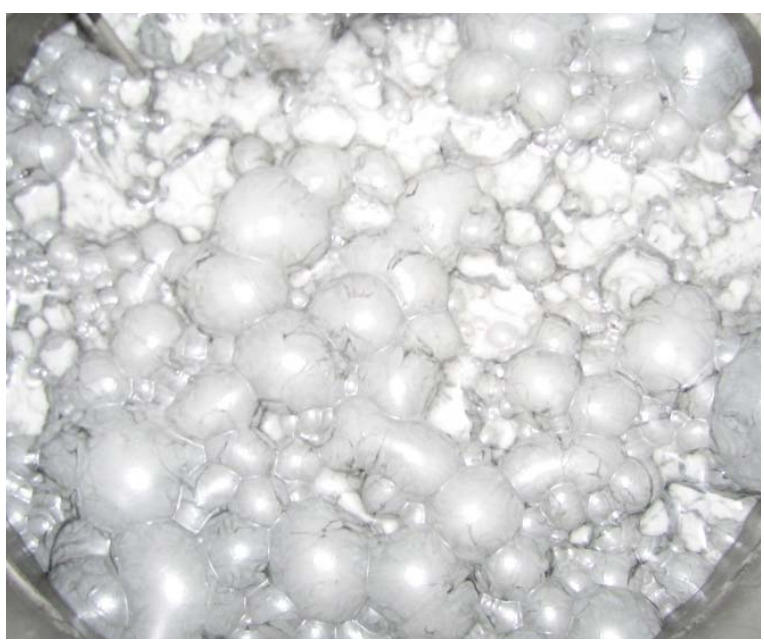

(b)

Figure 3-14 Simulant in at start of test day 2: a. Shows the CUF feed tank, thermocouple and discharge lines from the filtration graduated cylinder and bypass, b. Close-up of simulant

The third and final day of CUF testing, began with a IS concentration of approximately $15 \mathrm{wt} \%$ and the instability observed at the latter half of the previous day was immediately evident. Within minutes of starting operation, it became obvious that maintaining the flow conditions of $\mathrm{TMP}=40 \mathrm{psid}$ and $\mathrm{SV}=11 \mathrm{ft} / \mathrm{s}$ would not be possible. To maintain high filtration rates, the $\mathrm{TMP}=40$ psid was held constant by slowly closing valve V1, which resulted in the reduction of the SV. This also resulted in the slurry temperature to increase because there was less flow to transfer heat through the heat exchanger. When the slurry temperature reached the limit of $30^{\circ} \mathrm{C}$, valve V1 was reopened to increase flow, reducing the TMP. Eventually, the TMP dropped to the point that filtrate production ceased, forcing the termination of the test after approximately 15 hours of discontinuous operation, Figure 3-15. At that point the estimated solids loading was $18.3 \mathrm{wt} \%$ IS, but was subsequently measured to be $14.8 \mathrm{wt} \%$ IS, Figure $3-16$. The error bars shown for the measured weight percent insoluble solids data points on Figure 3-16 (horizontal \pm error bars) assume a conservative $\pm 20 \%$ variability in the single point measurements. Thus as the measured weight percent insoluble solids value increases, the error bars increase accordingly. 


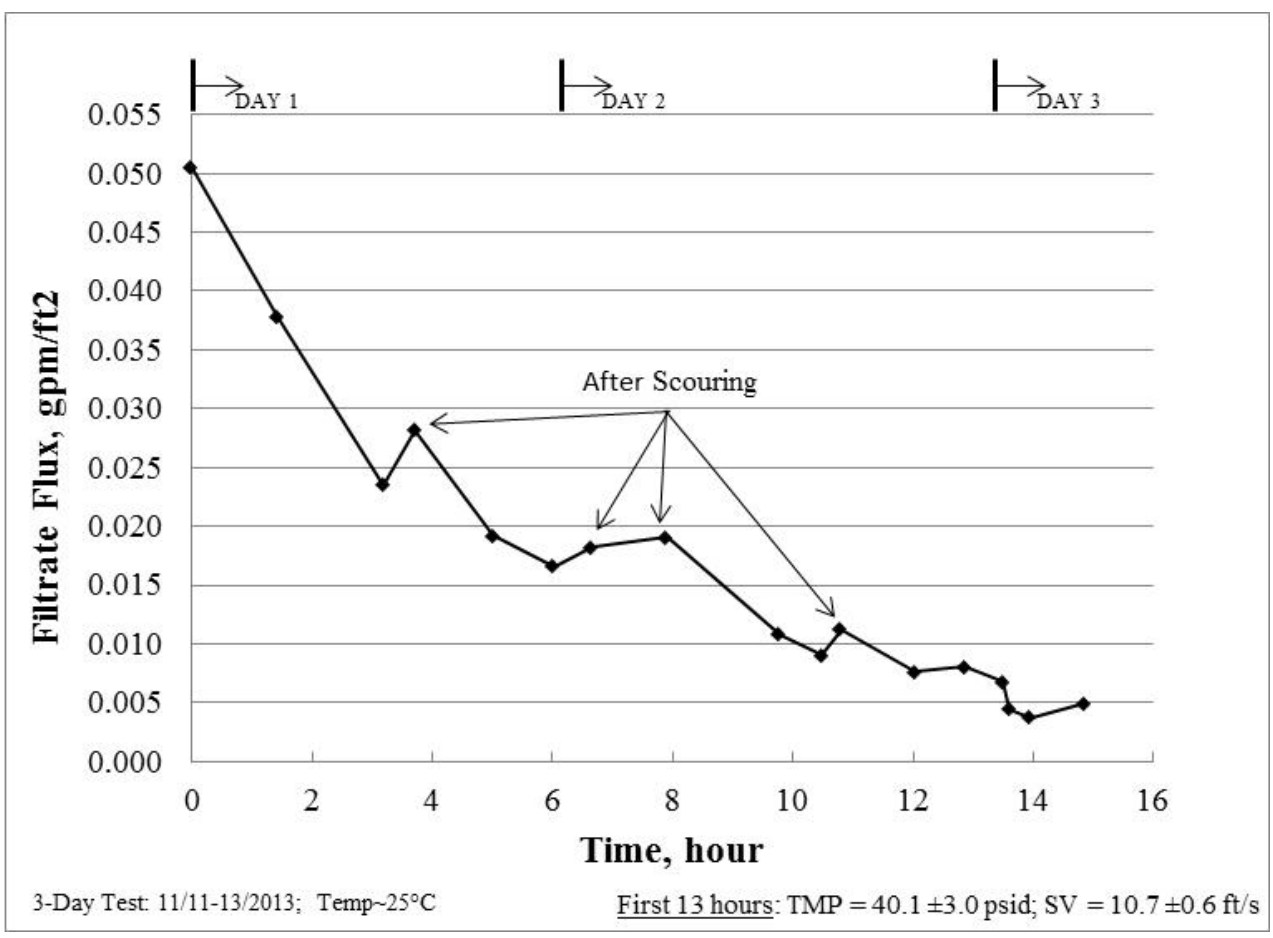

Figure 3-15 Dewatering filtrate flux versus time

As expected, as the simulant was filtered and the IS concentration increased, the filtrate flux decreased, Figure 3-16. This is generally because as the concentration increases, the waste stream density, consistency (plastic viscosity), and filter cake thickness also increase. During concentration, scouring was moderately effective in slightly improving the filtrate flux, which was performed four times, i.e., at approximately 3.5, 6.5, 8, and 11 hours. (Scouring is explained in Section 2.6.) These scouring activities can be seen as flow interruptions in Figure 3-13, followed by small peaks in filtrate flow rates in Figure3-15. 


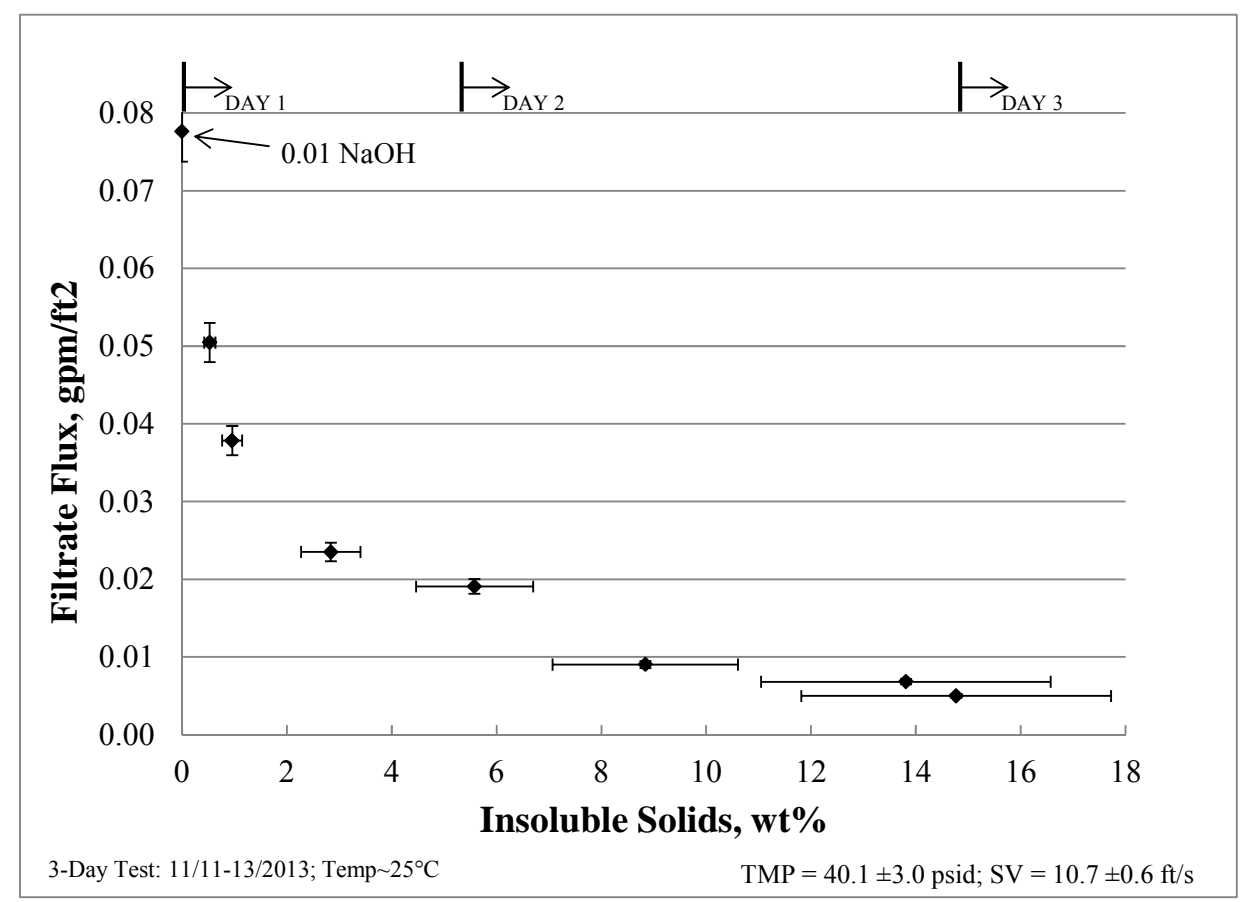

Figure 3-16 Dewatering filtrate flux versus measured solids loading

Table 3-8 shows analytical results of the filtrate samples that were collected during the CUF activities. The Step 3, 12, and 18 filtrates were only analyzed for specific gravity (density) whereas all the other filtrates were analyzed for both density and soluble species by ICP-ES. No significant fluctuations are observed for the soluble species $\mathrm{Al}, \mathrm{K}, \mathrm{Na}, \mathrm{P}$ and $\mathrm{S}$ as determined by the high precision in these values across all CUF testing. Results indicate that the simulant was over-diluted by $9 \%$. This was evidently due to slight differences in the measured slurry density between the original $1 \mathrm{~L}$ analytical batch and the sum of masses for batches prepared for the CUF. Note that this only affects the CUF tests, and not the stability tests described above. During CUF testing, the soluble Si increases by $\sim 4 \mathrm{X}$ as the second large batch of slurry was added to the CUF at the beginning of the second day of processing. It is possible that this increase in Si could be due to any minor differences in temperature during the batch 1 and batch 2 simulant preparations, since the temperature fluctuated due to chemical addition and reactions. All of the Si values for the CUF filtrates (48 to $65 \mathrm{mg} / \mathrm{L}$ for the early samples and 194 to 222 $\mathrm{mg} / \mathrm{L}$ for the latter samples) are significantly higher than the $24 \mathrm{mg} / \mathrm{L}$ determined in the initial 1 Liter sample filtrate. The total amount of Si added to the simulant was $504 \mathrm{mg} / \mathrm{L}$, so more than half was insoluble in all samples. Comparison of the soluble sodium in the slurries used in the CUF and the initial 1 Liter analytical sample indicates that the larger batches were slightly diluted as the 1 Liter $\left[\mathrm{Na}^{+}\right]$of $115,500 \mathrm{mg} / \mathrm{L}$ is about $10 \%$ higher than the average CUF slurry filtrate $\left[\mathrm{Na}^{+}\right]$value of $104,714 \mathrm{mg} / \mathrm{L}$. This is also evident in comparison of the 1 Liter filtrate density $(1.229 \mathrm{~g} / \mathrm{ml})$ vs. the average of the CUF filtrates of $1.208 \mathrm{~g} / \mathrm{mL}$. 
Table 3-8 Analytical Results for CUF Filtrate and Slurry Samples

\begin{tabular}{|c|c|c|c|c|c|c|c|c|c|c|}
\hline Element & $\begin{array}{c}\text { Step } 3 * \\
(11 / 11 / 13) \\
\text { Post- } \\
\text { recirc. }\end{array}$ & Step 4 & Step 5 & Step 6 & Step 7 & Step $9 *$ & $\begin{array}{c}\text { Step 10 } \\
(11 / 11 / 13)\end{array}$ & $\begin{array}{c}\text { Step 10A } \\
(11 / 12 / 13) \\
\text { Pre-mix }\end{array}$ & $\begin{array}{c}\text { Step } \\
10 A^{*} \\
(11 / 12 / 13) \\
\text { Post-mix }\end{array}$ & $\begin{array}{c}\text { Step } \\
10 \mathrm{~B} \\
(10: 15 \\
\text { a.m. })\end{array}$ \\
\hline & & $(\mathrm{mg} / \mathrm{L})$ & & $(\mathrm{mg} / \mathrm{L})$ & & $(\mathrm{mg} / \mathrm{L})$ & & & $(\mathrm{mg} / \mathrm{L})$ & \\
\hline $\mathrm{Al}$ & - & 7640 & - & 7620 & - & 7480 & - & - & 7740 & - \\
\hline $\mathrm{K}$ & - & 1230 & - & 1250 & - & 1290 & - & - & 1340 & - \\
\hline $\mathrm{Na}$ & - & 100000 & - & 103000 & - & 106000 & - & - & 110000 & - \\
\hline $\mathrm{P}$ & - & 790 & - & 789 & - & 579 & - & - & 571 & - \\
\hline $\mathrm{S}$ & - & 2120 & - & 2110 & - & 2210 & - & - & 2380 & - \\
\hline \multirow[t]{2}{*}{$\mathrm{Si}$} & - & 65 & - & 60 & - & 57.9 & - & - & 48.1 & - \\
\hline & & (M) & & (M) & & (M) & & & (M) & \\
\hline Na molarity & - & 4.35 & - & 4.48 & - & 4.61 & - & - & 4.78 & - \\
\hline \multirow[t]{2}{*}{$\begin{array}{c}\text { Na molarity / } \\
5 \mathrm{M} \\
\end{array}$} & - & 0.87 & - & 0.90 & - & 0.92 & - & - & 0.96 & - \\
\hline & $(\mathrm{g} / \mathrm{ml})$ & $(\mathrm{g} / \mathrm{ml})$ & & $(\mathrm{g} / \mathrm{ml})$ & & $(\mathrm{g} / \mathrm{ml})$ & & & $(\mathrm{g} / \mathrm{ml})$ & \\
\hline \multirow[t]{2}{*}{$\begin{array}{c}\text { Sp.G. } \\
( \pm 10 \%)\end{array}$} & 1.183 & 1.197 & - & 1.192 & - & 1.219 & - & - & 1.220 & - \\
\hline & $(w t \%)$ & & $(w t \%)$ & & $(\mathrm{wt} \%)$ & & $(w t \%)$ & $(w t \%)$ & $(w t \%)$ & $(w t \%)$ \\
\hline $\mathrm{W}_{\mathrm{ts}}$ & 22.91 & - & 23.80 & - & 26.87 & - & 29.89 & 28.86 & 30.36 & 30.53 \\
\hline $\mathrm{W}_{\mathrm{ds}}$ & 22.38 & - & 22.84 & - & 24.04 & - & 24.96 & 22.50 & 24.37 & 24.96 \\
\hline $\mathrm{W}_{\text {is }}$ & 0.53 & - & 0.96 & - & 2.84 & - & 4.94 & 6.37 & 5.00 & 5.58 \\
\hline
\end{tabular}

\begin{tabular}{|c|c|c|c|c|c|c|c|c|c|}
\hline Element & $\begin{array}{c}\text { Step } \\
10 B(12: 03 \\
\text { p.m. })\end{array}$ & Step 12 & Step 15 & $\begin{array}{l}\text { Step } \\
16\end{array}$ & Step 17 & $\begin{array}{c}\text { Step } 18 \\
(11 / 13 / 13)\end{array}$ & All Avg. & St. Dev. & $\%$ RSD \\
\hline & $(\mathrm{mg} / \mathrm{L})$ & & $(\mathrm{mg} / \mathrm{L})$ & & $(\mathrm{mg} / \mathrm{L})$ & & $(\mathrm{mg} / \mathrm{L})$ & $(\mathrm{mg} / \mathrm{L})$ & \\
\hline $\mathrm{Al}$ & 7180 & - & 7900 & - & 7240 & - & 7543 & 261 & 3.5 \\
\hline $\mathrm{K}$ & 1310 & - & 1410 & - & 1360 & - & 1313 & 63 & 4.8 \\
\hline $\mathrm{Na}$ & 101000 & - & 111000 & - & 102000 & - & 104714 & 4386 & 4.2 \\
\hline $\mathrm{P}$ & 660 & - & 756 & - & 688 & - & 690 & 93 & 13.4 \\
\hline $\mathrm{S}$ & 2240 & - & 2490 & - & 2370 & - & 2274 & 143 & 6.3 \\
\hline \multirow[t]{2}{*}{$\mathrm{Si}$} & 194 & - & 222 & - & 206 & - & 122 & 81 & 66.1 \\
\hline & (M) & & (M) & & (M) & & (M) & (M) & \\
\hline $\mathrm{Na}$ molarity & 4.39 & - & 4.83 & - & 4.44 & - & 4.55 & 0.19 & 4.2 \\
\hline \multirow[t]{2}{*}{$\begin{array}{c}\text { Na molarity / } \\
5 \mathrm{M} \\
\end{array}$} & 0.88 & - & 0.97 & - & 0.89 & - & 0.91 & 0.04 & 4.2 \\
\hline & $(\mathrm{g} / \mathrm{ml})$ & $(\mathrm{g} / \mathrm{ml})$ & $(\mathrm{g} / \mathrm{ml})$ & & $(\mathrm{g} / \mathrm{ml})$ & $(\mathrm{g} / \mathrm{ml})$ & $(\mathrm{g} / \mathrm{ml})$ & $(\mathrm{g} / \mathrm{ml})$ & \\
\hline \multirow[t]{2}{*}{$\begin{array}{c}\text { Sp.G. } \\
( \pm 10 \%)\end{array}$} & 1.203 & 1.203 & 1.270 & & 1.196 & 1.196 & 1.208 & 0.025 & 2.0 \\
\hline & & $(w t \%)$ & & $(w t \%)$ & & $(w t \%)$ & & & \\
\hline $\mathrm{W}_{\mathrm{ts}}$ & - & 33.00 & - & 37.95 & - & 39.59 & - & - & - \\
\hline $\mathrm{W}_{\mathrm{ds}}$ & - & 24.18 & - & 24.17 & - & 24.86 & - & - & - \\
\hline $\mathrm{W}_{\text {is }}$ & - & 8.84 & - & 13.81 & - & 14.77 & - & - & - \\
\hline
\end{tabular}

* Before Step 3 the initial 5 L slurry at target $0.8 \mathrm{wt} \%$ IS added; Before Step 9 (Step 8) a second batch of $5 \mathrm{~L}$ slurry at target 3.2 wt $\%$ IS added; After step 10A Pre-mix on 11/12/13, a third batch of $2.25 \mathrm{~L}$ slurry at target $7 \mathrm{wt} \%$ IS added. 
Table 3-9 shows the results of slurry rheology measurements determined on the starting $5 \mathrm{M}$ $\left[\mathrm{Na}^{+}\right]$slurry and slurries obtained from the CUF during the middle (after Step 12) and end of processing after Step 18. The Bingham Plastic Model of the down curve of the method was used to calculate a plastic viscosity and yield stress for these slurries. The yield stress for the initial and middle post-step 12 slurries was not measurable.

Table 3-9 Rheology Data of CUF Slurries

\begin{tabular}{|c|c|c|c|c|}
\hline Sample & $\begin{array}{c}\text { Plastic } \\
\text { Viscosity (cP) } \\
\end{array}$ & $\begin{array}{l}\text { Yield Stress } \\
(\mathbf{P a})\end{array}$ & $\mathbf{R}^{2}$ & Range $\left(\mathrm{s}^{-1}\right)$ \\
\hline $\begin{array}{c}\text { Initial Pre-CUF Rep } \\
1(0.5 \mathrm{wt} \%)\end{array}$ & 1.9 & NA & 0.7486 & $0-350$ \\
\hline $\begin{array}{c}\text { Initial Pre-CUF Rep } \\
2\left(0.5 \mathrm{wt}^{0} \%\right)\end{array}$ & 1.9 & NA & 0.7584 & $0-350$ \\
\hline $\begin{array}{l}\text { Initial Pre-CUF Rep } \\
3(0.5 \mathrm{wt} \%)\end{array}$ & 1.8 & NA & 0.8578 & $0-350$ \\
\hline $\begin{array}{c}\text { Post Step } 12 \text { CUF } \\
\text { Rep } 1(5.6 \mathrm{wt} \%)\end{array}$ & 6.0 & NA & 0.9924 & $30-1000$ \\
\hline $\begin{array}{l}\text { Post Step } 12 \text { CUF } \\
\text { Rep } 2(5.6 \mathrm{wt} \%)\end{array}$ & 5.9 & NA & 0.9952 & $30-1000$ \\
\hline $\begin{array}{l}\text { Post Step } 12 \text { CUF } \\
\text { Rep } 3(5.6 \mathrm{wt} \%)\end{array}$ & 6.0 & NA & 0.9943 & $30-1000$ \\
\hline $\begin{array}{l}\text { Post Step } 18 \text { CUF } \\
\text { Rep } 1(14.8 \mathrm{wt} \%)\end{array}$ & 35.4 & 5.3 & 0.9987 & $30-1000$ \\
\hline $\begin{array}{l}\text { Post Step } 18 \text { CUF } \\
\text { Rep } 2(14.8 \mathrm{wt} \%)\end{array}$ & 33.1 & 5.0 & 0.9984 & $30-1000$ \\
\hline $\begin{array}{l}\text { Post Step } 18 \mathrm{CUF} \\
\text { Rep } 3(14.8 \mathrm{wt} \%)\end{array}$ & 38.7 & 5.0 & 0.9994 & $30-1000$ \\
\hline
\end{tabular}

As explained in Appendix C, during scouring, the filtrate flux is temporarily stopped by closing the valve, causing the TMP to go to zero, and increasing the SV by about $50 \%$. In this test sequence, the SV during scouring was $\sim 16 \mathrm{ft} / \mathrm{s}$, versus the normal operational velocity of $11 \mathrm{ft} / \mathrm{s}$. After reaching $\sim 10 \mathrm{wt} \%$ IS, the pump was unable to reach the target SV during scouring, and it was approximately to $13 \mathrm{ft} / \mathrm{s}$. Despite the lower scouring velocity, the original $0.009 \mathrm{gpm} / \mathrm{ft}^{2}$ filtrate flux increased to $0.0113 \mathrm{gpm} / \mathrm{ft}^{2}$, which was a $25 \%$ improvement. Scouring was effective in all cases, with the first use raising the flux approximately $40 \%$. This was consistent with past observations (Duignan et al., 2011). Backpulsing was not attempted during this portion of the test. Backpulsing has been tried many times in the past (Duignan, 2003, Daniel et al., 2010). Prior testing with these filters have shown limited success at the start of filtration, but backpulsing eventually becomes ineffective with time and accelerates depth fouling of the filter media. However, as is explained in Appendix C, when the test was complete the simulant was 
diluted back to measured $13.5 \mathrm{wt} \%$, basically, restoring it to the point where test day $3 \mathrm{began}$, in order to determine if a backpulse would be helpful. It was found to not affect the flux at all; however, at that point, the filter cake was well adhered to the filter wall, so this post-test demonstration indicates that the backpulse effectiveness was inconclusive. Evidently, the $\sim 15$ hours of continuous shearing and issues with temperature control modified the morphology and particle size of the slurry such that it did not return to the earlier performance. The smaller particle size measured in the final samples is consistent with the observation that simple redilution does not restore the filtration rate.

Despite some challenges with the CUF testing, as the simulant concentrated from 0.5 to $15 \mathrm{wt} \%$, the filter performance appears to be similar to past data (Duignan, 2003). This can be compared with a test with a $6 \mathrm{M}\left[\mathrm{Na}^{+}\right]$simulant of the Hanford Tank 241-AN-102 waste, filtered in the SRNL pilot scale crossflow test facility. That testing was performed in the pilot scale test facility with a crossflow filter with the same Mott 0.1 micron grade stainless steel media. However, the inside tube diameter was 0.5 inch and the filter length was 90 inches as compared to the CUF filter with a 0.375 inch inside diameter and length of 24 inches. The parameters of the simulant and filter were similar, as shown in Table 3-10, although the prior material was an iron-based simulated sludge slurry.

Table 3-10 Comparison between two different filter tests

\begin{tabular}{|c|c|c|c|c|c|c|c|c|}
\cline { 4 - 9 } & \multicolumn{4}{c|}{ Mott Crossflow Filter Parameters } \\
\hline & Sodium & Filtrate $\rho$ & Filtrate $\mu$ & I.D & Length & Rating & SV & TMP \\
\hline Batch & $\mathrm{M}$ & $\mathrm{g} / \mathrm{mL}$ & $\mathrm{cP}$ & in & in & $\mathrm{m}$ & $\mathrm{ft} / \mathrm{s}$ & $\mathrm{psid}$ \\
\hline 3A & 6 & 1.28 & 3.7 & 0.5 & 90 & 0.1 & 12 & 40 \\
\hline 3B & 6 & 1.28 & 3.7 & 0.5 & 90 & 0.1 & 12 & 40 \\
\hline This Work & 5 & 1.20 & 1.9 & 0.375 & 24 & 0.1 & 11 & 40 \\
\hline
\end{tabular}

What was observed in the data of the earlier test (Duignan, 2003) is the effect of backpulsing, as shown in Figure 3-17. The AN-102 simulant was also very challenging, since it was high in sodium salts, density, and viscosity. The several spikes in the descending flux curves are due to the backpulsing, which was initiated when the simulant reached approximate $2 \mathrm{wt} \%$ IS. However, for Batch $\mathrm{C}$, the backpulse became ineffective very quickly, and after $3 \mathrm{wt} \%$ IS, no improvement of filtrate flux was realized upon backpulsing. For the test Batch 3A simulant, backpulses became ineffective after approximately $7 \mathrm{wt} \%$. In any case, the improved flux of the backpulse only lasted one to two hours, and it appears to accelerate depth fouling because removing the trace solids comprising the surface filter cake exposes the media to the smallest particles in the waste stream. Furthermore, the process efficiency is reduced because the filtrate used to backpulse is returned back into the waste stream that then needs to be removed a second time. 


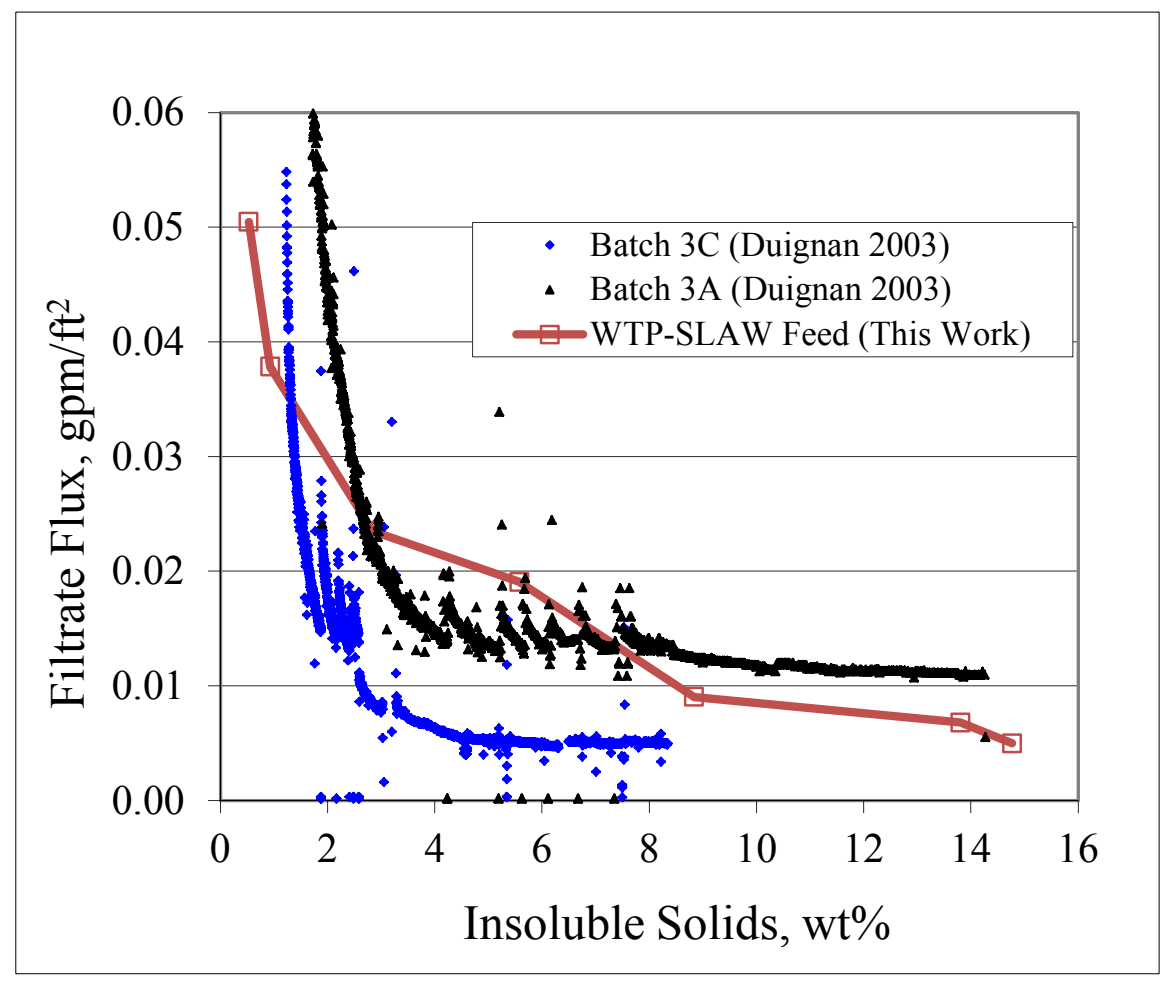

Figure 3-17 Crossflow filtration of two simulants: two batches of Hanford $\left.6 \mathrm{M}^{\mathrm{N}} \mathrm{Na}^{+}\right] \mathrm{AN}$ 102 waste to the current $5 \mathrm{M}\left[\mathrm{Na}^{+}\right]$SLAW feed

\subsection{Process Impact Estimates}

Results indicate that the HTWOS-calculated composition will generate approximately $0.8 \mathrm{wt} \%$ insoluble solids when it is cooled and diluted to $5 \mathrm{M}\left[\mathrm{Na}^{+}\right]$. Once formed, this solution appears stable, with no significant additional precipitation after several weeks.

Filtration of these insoluble solids is roughly comparable to prior filtration performance with sludge simulants. Concentrating the slurry to $\sim 14 \mathrm{wt} \%$ reached the maximum capabilities of the filtration system equipment for pump-ability and temperature control. The solids were observed to be somewhat shear-sensitive, since re-dilution to a lower $\mathrm{wt} \%$ solids did not restore the filter flux, consistent with the observed smaller particle size.

\subsection{Conclusions}

The insoluble solids formed during these tests included natrophosphate, natroxalate, and a sodium aluminosilicate compound. The solids were relatively stable and well behaved, but were somewhat shear sensitive. Filtration rates were in the range of those observed with tank slurry simulants, even though their chemical speciation is considerably different. Recirculation of the slurry through the CUF caused reduction in slurry particle size and lower filtration flow rates. Concentration of the slurry caused challenges in the CUF system, including unstable flow rates in the system and temperature excursions. Chemical cleaning of the crossflow filter was readily accomplished with acid. 


\subsection{References}

Brooks, K.P., Bredt, P.R., Golcar, G.R., Hartley, S.A., Jagoda, L.K., Rappe, K.G., Urie, M.W., "Characterization, Washing, Leaching, and Filtration of C-104," PNWD-3024 (or BNFL-RPT030), May 2000. [0.375-in ID, 24-in long, $0.1 \mu \mathrm{m}$ rated CUF filter tube from Mott Inc.]

Daniel, R.C., Billing, J.M., Bontha, J.R. Brown, C.F., Eslinger, P.W., Hanson, B.D., Huckaby, J.L., Karri, N.K., Kimura, M.L., Kurath, D.E., Minette, M.J., "EFRT M-12 Issue Resolution: Comparision of Filter Performance at PEP and CUF Scale," WTP-RPT-185, Rev. 1 (or PNNL18498, Rev. 1), January 2010. [0.5-inch ID CUF, 24-in long, $0.1 \mu \mathrm{m}$ rated CUF filter tube from Mott Inc.]

Daniel, R.C., Billing, J.M., Burns, C.A., Peterson, R.A., Russell, R.L., Schonewill, P.P., Shimskey, R.W., "Filtration Understanding: FY10 Testing Results and Filtration Model Update," PNNL-20299 (or EMSP-RPT-008), April 2011. [0.5-inch ID CUF, 24-in long, $0.1 \mu \mathrm{m}$ rated CUF filter tube from Mott Inc.]

Duignan, M.R., "Final Report: Pilot-scale Cross-Flow Ultrafiltration Test Using Hanford Site Tank 241-AN-102 Waste Simulant (U)," WSRC-TR-2003-00204 (or SRT-RPP-2003-00087), May 2003. [0.5-in ID, 90-in long, $0.1 \mu \mathrm{m}$ rated CUF filter tube from Mott Inc.]

Duignan, M.R., Nash, C.A., Poirier, M.R., “Crossflow Filtration: EM-31, WP-2.3.6,” SRNLSTI-2011-00071, February 2011. [0.375-in ID, 24-in long, $0.1 \mu \mathrm{m}$ rated CUF filter tube from Mott Inc. among two others.]

Hansen, E.K. and Calloway, T.B., "Characterization of Simulant LAW Envelope A, B, and C with Glass Formers,” WSRC-TR-2000-00298, Rev. 0, SRT-RPP-2000-00004, August, 2000.

Icenhower, J.P., Qafoku, N.P., Martin, W.J., Zachara, J.M., The Geochemistry of Technetium: A Summary of the Behavior of an Artificial Element in the Natural Environment, PNNL-18139, December 2008

Icenhower, J.P., Qafoku, N.P., Martin, W.J., Zachara, J.M., The Biogeochemistry of Technetium: A review of the behavior of an Artificial Element in the Natural Environment, American Journal of Science, 310, 721-752, October 2010.

Mann, F.M., Puigh, R.J., Khaleel, R., Finfrock, S., McGrail, B.P., Bacon, D.H., Serne, R.J., Risk Assessment Supporting the Decision on the Initial Selection of Supplemental ILAW Technologies, RPP-17675, Rev. 0, September 29, 2003

Mann, N.R., Herbst, R.S., Garn, T.G., Poirier, M.R., Fink, S.D., "Alternative Ultrafiltration Membrane Testing for the SRS Baseline Process," INEEL/EXT-04-01933, June 2004 [0.375-in ID, 24-in long, $0.1 \mu \mathrm{m}$ rated CUF filter tube from Mott Inc., and others]

McCabe, D.J., Technetium Removal Technology Development Plan for Elutable Ion Exchange, SRNL-STI-2013-00049, January, 2013 
Nash, C.A., "Filtration of Tank 48H Contents with a Cells Unit Filter (U)," WSRC-TR-95-0483, December 8, 1995. [0.375-in ID, 18-in long, $0.5 \mu \mathrm{m}$ rated CUF filter tube from Mott Inc.]

Nash, C.A. Saito, H.H., Wilmarth, W.R., "Strontium-Transuranic Precipitation and Crossflow Filtration 241-AN-102 Large C," WSRC-TR-2000-00506 (or SRT-RPP-2001-00006 or BNF0003-98-0317), December 2000 [0.375-in ID, 24-in long, $0.1 \mu \mathrm{m}$ rated CUF filter tube from Mott Inc.]

Nash, C.A. Rosencrance, S.W., Wilmarth, W.R., "Entrained Solids, Strontium-Transuranic Precipitation and Crossflow Filtration 241-AN-102 Small C," WSRC-TR-2000-00341 (or SRTRPP-2000-00003), August 2000 [0.375-in ID, 24-in long, $0.1 \mu \mathrm{m}$ rated CUF filter tube from Mott Inc.]

Pareizs, J.M., "Weight Percent Solids Determination Using a Furnace or Oven,” L29, ITS-0078, Rev. 1, October, 2012

Poirier, M.R., Fink, S.D., "Recommendation for Using Smaller $(0.1 \mu)$ Pore-Size Media for Filtration in Salt Waste Processing Project," WSRC-TR-2002-00341, August 5, 2002

Poirier, M.R., Burket, P., Siler, J.L., Man, J.R., "Filtration, Washing, and Leaching of a Hanford AY-102/C-106 Sample,” WSRC-TR-2003-00240 (or SRT-RPP-2003-00110), September 2003 [0.375-in ID, 24-in long, $0.1 \mu \mathrm{m}$ rated CUF filter tube from Mott Inc.]

Russell, R.L., Westsik, J.H., Jr., Swanberg, D.J., Eibling, R.E., Cozzi, A.D., Lindberg, M.J., Josephson, G.B., Rinehart, D.E., Letter Report: LAW Simulant Development for Cast Stone Screening Tests, PNNL-22352, March, 2013

SVF-2748, 2013, "SVF-2748 Rev 0, Second LAW Tc IX Mass Balance.xlsx," MMR-13008_Case-0-7.4-8.3r1-2013-04-03-at-17-24-53, Washington River Protection Solutions, LLC, Richland, Washington.

Zamecnik, J.R., Baich, M.A., "Evaluating The Effects of Tri-Butyl Phosphate And Normal Paraffin Hydrocarbon In Simulated Low-Activity Waste Solution of Ultrafiltration," WSRC-TR2002-00108 (or SRT-RPP-2002-00041), April 2002 [0.375-in ID, 24-in long, $0.1 \mu \mathrm{m}$ rated CUF filter tube from Mott Inc.]

Zamecnik, J.R., Baich, M.A., Hansen, E.K., Poirier, M.R., "AN-102 Simulant SR/TRU Precipitation and Ultrafiltration," WSRC-TR-2003-00056 (or SRT-RPP-2002-00231), February 2003 [0.375-in ID, 24-in long, $0.1 \mu \mathrm{m}$ rated CUF filter tube from Mott Inc.]

Zamecnik, J.R., Poirier, M.R., Duignan, M.R., Nash, C.A., Baich, M.A., "Filtration of a Hanford Site Tank 241-AN-102 Waste Sample with Alternative SR/TRU Precipitation Conditions and Bench and Pilot Scales," WSRC-MS-2003-00756, March 2004a [0.375-in ID, 24-in long, $0.1 \mu \mathrm{m}$ rated CUF filter tube from Mott Inc.] 
Zamecnik, Burket, P.R., Eibling, R.E., "Tank 241-AN-102 Simulant Development Ultrafiltration, and Washing," WSRC-MS-2003-00547 (or SRT-RPP-2003-00240), March 2004b [0.375-in ID, 24-in long, $0.1 \mu \mathrm{m}$ rated CUF filter tube from Mott Inc.] 
Appendix A. Simulant Formulations

Table A-1. Simulant Formulation for 1-liter Analytical Sample

\subsection{Na WTP LAW Feed}

Simulant

Volume of Feed

\begin{tabular}{|l|l|}
\hline 1000 & $\mathrm{~mL}$ \\
\hline
\end{tabular}

Tare a

1000

mL Volumetric Flask/Lid/Stir-bar

Volumetric Flask Tare Weight grams

To the Volumetric Flask add

\begin{tabular}{|l|c|c|}
\cline { 2 - 3 } \multicolumn{1}{c|}{} & grams & Actual Wt, grams \\
\hline Water & 100 & \\
\hline
\end{tabular}

Transition Metals and Complexing agents (small amounts of water can be used for rinse)

\begin{tabular}{|l|c|c|c|}
\hline Compounds & Formula & Mass Needed & Actual Wt, grams \\
\hline Potassium Nitrate & $\mathrm{KNO}_{3}$ & 5.26 & \\
\hline Sodium Chloride & $\mathrm{NaCl}$ & 4.09 & \\
\hline Sodium Fluoride & $\mathrm{NaF}$ & 8.06 & \\
\hline Sodium Sulfate & $\mathrm{Na}_{2} \mathrm{SO}_{4}$ & 15.62 & \\
\hline
\end{tabular}

Mix the mixture to dissolve then add the following

\begin{tabular}{|l|c|c|c|}
\hline $\begin{array}{l}\text { Add (small amounts of water can be } \\
\text { used for rinse) }\end{array}$ & Formula & Mass Needed & Actual Wt, grams \\
\hline Sodium Hydroxide & $\mathrm{NaOH}, 50 \mathrm{wt} \%$ & 340.56 & \\
\hline Aluminum Nitrate & $\mathrm{Al}\left(\mathrm{NO}_{3}\right)_{3} \cdot 9 \mathrm{H}_{2} \mathrm{O}$ & 197.69 & \\
\hline Sodium Metasilicate Pentahydrate & $\mathrm{Na}_{2} \mathrm{SiO}_{3} \cdot 5 \mathrm{H}_{2} \mathrm{O}$ & 6.15 & \\
\hline Sodium Phosphate & $\mathrm{Na}_{3} \mathrm{PO}_{4} \cdot 12 \mathrm{H}_{2} \mathrm{O}$ & 44.85 & \\
\hline Sodium Acetate & $\mathrm{NaCH}_{3} \mathrm{COO} 3 \mathrm{H}_{2} \mathrm{O}$ & 8.44 & \\
\hline Sodium Oxalate & $\mathrm{Na}_{2} \mathrm{C}_{2} \mathrm{O}_{4}$ & 4.82 & \\
\hline
\end{tabular}




\begin{tabular}{|l|c|c|}
\hline Add & grams & Actual Wt, grams \\
\hline Water & 100 & \\
\hline
\end{tabular}

Mix thoroughly. All of the solids should dissolve.

\begin{tabular}{|l|c|c|c|}
\hline Add & Formula & Mass Needed & Actual Wt, grams \\
\hline Sodium Carbonate & $\mathrm{Na}_{2} \mathrm{CO}_{3}$ & 37.84 & \\
\hline
\end{tabular}

Mix thoroughly.

\begin{tabular}{|l|c|c|c|}
\hline Add & Formula & Mass Needed & Actual Wt, grams \\
\hline Sodium Nitrate & $\mathrm{NaNO}_{3}$ & 67.48 & \\
\hline Sodium Nitrite & $\mathrm{NaNO}_{2}$ & 66.24 & \\
\hline Water & $\mathrm{H}_{2} \mathrm{O}$ & 100 & \\
\hline
\end{tabular}

Mix thoroughly and dilute to the mark. Note: move stir bar to above dilution mark for final dilution.

Record Final Gross Weight

Calculate/Record the Density

(Final mass - Initial mass)/1000

\section{Solution Labeling}

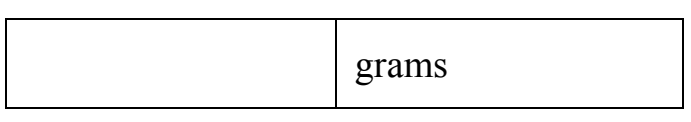

(flask,lid,stirbar,sample)

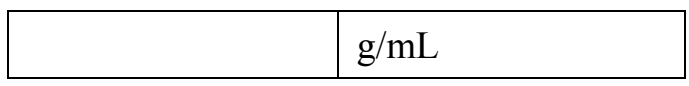

\subsection{Na WTP LAW Feed Simulant}

Technician or Researcher

Balance \# 
Table A-2. Simulant Formulation for 5-liter CUF Sample

\section{Full 7.75 M Na Mass Based}

\section{Volume of Feed}

Obtain a Simulant Bottle larger than

Record mass of Simulant Container

Total Mass of Simulant to be prepared
3188

$\mathrm{mL}$

To the container/stir bar add the following with mixing

Transition Metals and initial soluble salts

\begin{tabular}{|l|c|c|l|}
\hline Compounds & Formula & Mass Needed & Actual Wt, grams \\
\hline Water & $\mathrm{H}_{2} \mathrm{O}$ & 159.4 & \\
\hline Potassium Nitrate & $\mathrm{KNO}_{3}$ & 16.76 & \\
\hline Sodium Chloride & $\mathrm{NaCl}$ & 13.04 & \\
\hline Sodium Fluoride & $\mathrm{NaF}_{2}$ & 25.70 & \\
\hline Sodium Sulfate & $\mathrm{Na}_{2} \mathrm{SO}_{4}$ & 49.81 & \\
\hline Water For Rinsing & $\mathrm{H}_{2} \mathrm{O}$ & 159.4 & \\
\hline
\end{tabular}

Mix the mixture to dissolve then add the following

\begin{tabular}{|l|l|c|c|}
\hline Add & Formula & Mass Needed & Actual Wt, grams \\
\hline Sodium Hydroxide & $\mathrm{NaOH}, 50 \mathrm{wt} \%$ & 1085.71 & \\
\hline Aluminum Nitrate & $\mathrm{Al}\left(\mathrm{NO}_{3}\right)_{3} 9 \mathrm{H}_{2} \mathrm{O}$ & 630.25 & \\
\hline
\end{tabular}

Mix to make sure the Aluminum is reacted and dissolved.

\begin{tabular}{|l|c|c|c|}
\hline Add & Formula & Mass Needed & Actual Wt, grams \\
\hline Water & $\mathrm{H}_{2} \mathrm{O}$ & 159.4 & \\
\hline Sodium Metasilicate Pentahydrate & $\mathrm{Na}_{2} \mathrm{SiO}_{3} \cdot 5 \mathrm{H}_{2} \mathrm{O}$ & 19.61 & \\
\hline Sodium Phosphate Tribasic & $\mathrm{Na}_{3} \mathrm{PO}_{4} \cdot 12 \mathrm{H}_{2} \mathrm{O}$ & 143.00 & \\
\hline Sodium Acetate & $\mathrm{NaCH}_{3} \mathrm{COO} \cdot 3 \mathrm{H}_{2} \mathrm{O}$ & 26.90 & \\
\hline Sodium Oxalate & $\mathrm{Na}_{2} \mathrm{C}_{2} \mathrm{O}_{4}$ & 15.38 & \\
\hline
\end{tabular}


Mix thoroughly. All of the solids should dissolve.

\begin{tabular}{|l|c|c|c|}
\hline Add & Formula & Mass Needed & Actual Wt, grams \\
\hline Sodium Carbonate & $\mathrm{Na}_{2} \mathrm{CO}_{3}$ & 120.63 & \\
\hline Water & $\mathrm{H}_{2} \mathrm{O}$ & 318.8 & \\
\hline
\end{tabular}

Mix thoroughly to dissolve the carbonate.

\begin{tabular}{|l|c|c|c|}
\hline Add & Formula & Mass Needed & Actual Wt, grams \\
\hline Sodium Nitrate & $\mathrm{NaNO}_{3}$ & 215.13 & \\
\hline Sodium Nitrite & $\mathrm{NaNO}_{2}$ & 211.17 & \\
\hline Water & $\mathrm{H}_{2} \mathrm{O}$ & 700.99 & \\
\hline
\end{tabular}

Continue mixing until all of the salts dissolve. This may take several hours.

\section{Record Final Gross Weight}

Measure the Density

Solution Labeling

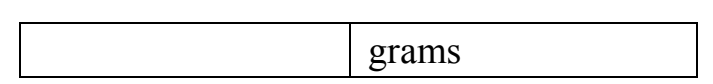

$\mathrm{g} / \mathrm{mL}$ 
Table A-3. Simulant Formulation for 15-liter CUF Sample

\section{Full 7.75 M Na Mass Based}

\section{Volume of Feed}

Obtain crab pot larger than

Record mass of Crab Pot

Total Mass of Simulant to be prepared
9564

$\mathrm{mL}$

grams

12691.428

grams

\section{$9564 \mathrm{~mL}$}

To the crab pot add the following with mixing

Transition Metals and initial soluble salts

\begin{tabular}{|l|c|c|c|}
\hline Compounds & Formula & Mass Needed & Actual Wt, grams \\
\hline Water & $\mathrm{H}_{2} \mathrm{O}$ & 478.2 & \\
\hline Potassium Nitrate & $\mathrm{KNO}_{3}$ & 50.28 & \\
\hline Sodium Chloride & $\mathrm{NaCl}$ & 39.12 & \\
\hline Sodium Fluoride & $\mathrm{NaF}_{2}$ & 77.11 & \\
\hline Sodium Sulfate & $\mathrm{Na}_{2} \mathrm{SO}_{4}$ & 149.43 & \\
\hline Water For Rinsing & $\mathrm{H}_{2} \mathrm{O}$ & 478.2 & \\
\hline
\end{tabular}

Mix the mixture to dissolve then add the following

\begin{tabular}{|l|l|c|c|}
\hline Add & Formula & Mass Needed & Actual Wt, grams \\
\hline Sodium Hydroxide & $\mathrm{NaOH}, 50 \mathrm{wt} \%$ & 3257.12 & \\
\hline Aluminum Nitrate & $\mathrm{Al}\left(\mathrm{NO}_{3}\right)_{3} 9 \mathrm{H}_{2} \mathrm{O}$ & 1890.74 & \\
\hline
\end{tabular}

Mix to make sure the Aluminum is reacted and dissolved.

\begin{tabular}{|l|c|c|c|}
\hline Add & Formula & Mass Needed & Actual Wt, grams \\
\hline Water & $\mathrm{H}_{2} \mathrm{O}$ & 478.2 & \\
\hline Sodium Metasilicate Pentahydrate & $\mathrm{Na}_{2} \mathrm{SiO}_{3} \cdot 5 \mathrm{H}_{2} \mathrm{O}$ & 58.84 & \\
\hline Sodium Phosphate & $\mathrm{Na}_{3} \mathrm{PO}_{4} \cdot 12 \mathrm{H}_{2} \mathrm{O}$ & 428.99 & \\
\hline Sodium Acetate & $\mathrm{NaCH}_{3} \mathrm{COO} \cdot 3 \mathrm{H}_{2} \mathrm{O}$ & 80.69 & \\
\hline Sodium Oxalate & $\mathrm{Na}_{2} \mathrm{C}_{2} \mathrm{O}_{4}$ & 46.14 & \\
\hline
\end{tabular}


Mix thoroughly. All of the solids should dissolve.

\begin{tabular}{|l|c|c|c|}
\hline Add & Formula & Mass Needed & Actual Wt, grams \\
\hline Sodium Carbonate & $\mathrm{Na}_{2} \mathrm{CO}_{3}$ & 361.89 & \\
\hline Water & $\mathrm{H}_{2} \mathrm{O}$ & 956.4 & \\
\hline
\end{tabular}

Mix thoroughly to dissolve the carbonate.

\begin{tabular}{|l|c|c|c|}
\hline Add & Formula & Mass Needed & Actual Wt, grams \\
\hline Sodium Nitrate & $\mathrm{NaNO}_{3}$ & 645.40 & \\
\hline Sodium Nitrite & $\mathrm{NaNO}_{2}$ & 633.52 & \\
\hline Water & $\mathrm{H}_{2} \mathrm{O}$ & 2102.97 & \\
\hline
\end{tabular}

Continue mixing until all of the salts dissolve. This may take several hours.

\section{Record Final Gross Weight}

Measure the Density

\section{Solution Labeling}

Technician or Researcher

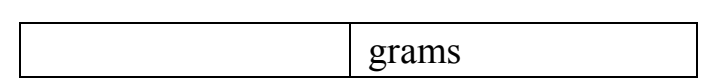

$\mathrm{g} / \mathrm{mL}$

\section{Balance \#}

\section{Full 7.75 M Na Mass Based}

\section{Date}


SRNL-STI-2014-00126

Revision 0

\title{
Appendix B. CUF R\&D Direction
}

\author{
R\&D Direction: 11/11/2013
}

\section{Operation of CUF for the 5 M [Na] WTP-LAW Simulant Filterability}

\subsection{Purpose}

This direction is to start up, operate, scour, backpulse, shut down, and clean the Cells Unit Filter (CUF) to support the crossflow filtering of a WTP-LAW simulant from its initial insoluble solids concentration up to a maximum attainable concentration of the target of $20 \mathrm{wt} \%$.

\subsection{Scope}

This procedure applies to personnel working with the CUF and assumes the test equipment has been setup, checked, and ready for use. The CUF contains one crossflow filter and slurry pump to feed slurry through the filter. Some liquid permeates through the filter wall (filtrate) and the remainder passes through the filter axially (concentrate). As solids accumulate on the filter wall, a backpulse removes accumulation. In a typical test, a technician will filter a slurry at constant feed pressure and concentrate flow rate while measuring filtrate flow.

\subsection{Terms and Definitions}

See List of Abbreviations

\subsection{Safety}

All SRNL safety rules apply.

Check operation of nearest safety shower and eyewash station before starting work. Inspect area surrounding the CUF for leaks during operation and at the end of each day. When working with the caustic simulant, nitric acid, or sodium hydroxide, operating equipment or taking data don lab coat, safety glasses, and nitrile gloves.

Review the relevant Material Safety Data Sheets before using any chemical.

Don leather gloves when working with hand tools. After the CUF has been run with chemicals, don nitrile gloves when operating the CUF, even with water. This is because acid, base, or slurry residues may remain on the valves or piping.

\subsection{Data Acquisition}

The acquiring of data is not directly addressed in this direction because it differs for each use of a CUF test facility. In general a CUF was designed to obtain data manually and to be recorded in a task notebook. However, it can be made to any level of automation. For 
the current test the slurry flow (velocity) was measured by a magnetic flowmeter, and the three pressures, i.e., slurry axial pressure, P2, slurry axial pressure drop, P1-P2, and filtrate pressure $\mathrm{P} 3$, were measured with capacitance-type pressure transducers. Those four 4 to $20 \mathrm{~mA}$ outputs were recorded on a computer. The feed tank temperature was also measured, but by a single thermocouple and was only recorded in the test notebook. The filtrate flowrate was measured by a graduated cylinder, read manually, and recorded in the test notebook; however, the process to obtain that measurement did need directions, which are listed below:

\section{Measuring filtrate flowrate}

This measurement assumes the CUF is in steady state operation, Section 7.0. Refer to the CUF schematic Figure2-3, and perform the following steps:

5.1 Redirect valve V10 from the filtrate exit tube to the graduated cylinder filtrate flowmeter.

5.2 Close valve V8 and allow the filtrate to fill the flowmeter to a readable graduation on the cylinder then redirect valve V10 back towards the filtrate exit tube.

5.3 While it is not necessary, Valve V8 can be carefully opened a small amount if the filtrate level is desired at an exact graduated mark, e.g., $20 \mathrm{ml}$. Allow the filtrate level to reach a mark and then close valve V8. Note, use the bottom of the cylinder meniscus to make the measurement. See figure below:

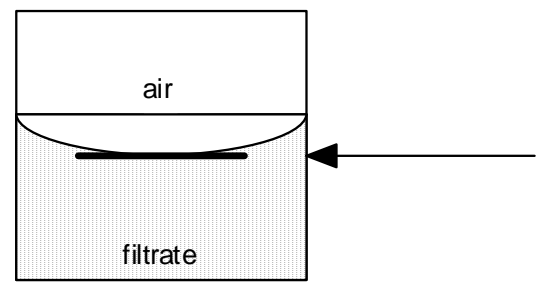

5.4 Start a stopwatch and redirect filtrate through 3-way valve V10 to the graduated cylinder simultaneously.

5.5 When the filtrate height reaches some desired mark, e.g., $80 \mathrm{ml}$, then stop the stopwatch and redirect filtrate through 3-way valve V10 to the filtrate exist tube.

5.6 Make a note of the filtrate collected and time elapsed in the test notebook.

5.7 Empty the graduated cylinder by opening, and leaving open, valve V8

\subsection{Start Up}

To begin the test with the CUF filled with DIF and then dilute caustic $(0.01 \mathrm{M} \mathrm{NaOH})$, the caustic is drained and then the slurry loop should be slowly filled with the test slurry and the filtrate loop shut so the filters are not challenged prematurely. As the slurry circulates in the slurry loop air may be seen in the reservoir because the air in the filtrate housing can be drawn into the slurry. Once the slurry was circulating at a constant, but very slow rate, e.g., the axial filter velocity was less than $1.6 \mathrm{ft} / \mathrm{s}(\sim 0.5 \mathrm{gpm})$ and air stops leaving the system from the slurry reservoir, then the filtrate valve is opened very slowly over approximately a 15-minute period. Once both the filtrate and slurry loops are filled, 
the filtrate flow is again stopped. Now the flow conditions to be used for filtering, i.e., axial velocity $(\mathrm{AV})=11 \mathrm{ft} / \mathrm{s}$ and a transmembrane pressure $(\mathrm{TMP})=40 \mathrm{psid}$, are established. With the filtrate flow established, the system is allowed to run about 2 hours to allow the filter cake to develop. After the cake was established, the filters received the initial 'scouring' for 15 to 20 minutes. The steps to perform these actions are listed below:

6.1 Circulate rinse water through cleaning loop, then flush out any sample valve of debris, purge the pressure transducer tubes of any solids, finally do a zero check of all pressure transducers and log the zeros.

6.2 Drain water thoroughly.

Set the CUF for slurry operation

6.3 Filtrate valve V4 MUST be closed as well as valves V5, V3 and V7 should be open.

6.4 Fully open downstream slurry valve, V1, and close drain valve, V2.

6.5 Slowly fill the CUF reservoir with 5 liters of simulant by pouring into the top of the feed tank. The simulant will be above the 5-liter mark because the system has not been filled yet.

6.6 Begin filling the slurry loop of the CUF by slowly opening valve V9 to allow air to start the pump. The flowrate should be no more than $0.5 \mathrm{gpm}$.

6.7 Once air is not noticeably entering into the slurry reservoir then increase the slurry pumps just enough to establish a slurry circulation. The filter velocities shall not exceed $5 \mathrm{ft} / \mathrm{s}(1.7 \mathrm{gpm})$.

6.8 Wait for the slurry circulation to be become steady and air no longer is bubbling into the slurry reservoir.

6.9 Fill the filtrate system by very slowly opening the filtrate valve V4 over a period of 10 to 15 minutes to full open.

6.10 If the filtrate system is filling too slow or stops filling, then slowly close the downstream slurry valve, $\mathrm{V} 1$ to reduce the axial velocity to below $1 \mathrm{ft} / \mathrm{s}(0.3 \mathrm{gpm})$ in order to increase the TMP.

6.11 After filtrate fills the return line to the slurry feed tank then purge the remaining instrument lines, i.e., to transducers, crossflow filter pressure drop, P1, and filtrate pressure, P3, and the sample line through valve V5. Return the collected filtrate back to the slurry feed tank.

6.12 After both the filtrate and slurry loops are full, shut the filtrate valve V4.

6.13 Bring the filter flow conditions to the chosen values, e.g., Axial Velocity of $11 \mathrm{ft} / \mathrm{s}$ ( $3.8 \mathrm{gpm}$ ) and TMP $=40 \mathrm{psid}$. (Note, since there is no filtrate flow now there cannot be any TMP; however, the system (slurry) pressure, P2, will be close to what it will be when the filter is operational.

6.14 Now, reopen the filtrate valve, V4, very slowly over a period of approximately 10 to 15 minutes to full open. While opening note the increasing TMP and do not allow the TMP to increase sharply, that is, the pressure should be increased slowly and smoothly during the 10 to 15 minutes. Note, most of the pressure is obtained in the first $1 / 8^{\text {th }}$ turn of $\mathrm{V} 4$, which is between 0.3 and 0.5 turns because 
V4 has $\sim 2.5$ turns to full open. That is, the 10 to 15 minute opening time must be applied to the first $1 / 8^{\text {th }}$ turn.

6.15 Readjust the slurry valves to obtain the chosen flow conditions, e.g., Axial Velocity of $11 \mathrm{ft} / \mathrm{s}$ and TMP $=40 \mathrm{psid}$.

6.16 Allow the filters to operate for approximately 2 hours and then perform the first scouring.

\subsection{Steady State Filter Operation - Dewatering or at constant slurry concentration}

7.1 Once previous Step 6.15 is performed the test facility is in steady state operation. It is just a matter of maintaining smooth operation.

7.2 The valve setting for steady-state filtering is:

\begin{tabular}{|c|c|c|c|}
\hline Valve & Function & $\begin{array}{c}\text { Filtering - } \\
\text { Dewatering }\end{array}$ & $\begin{array}{c}\text { Filtering - } \\
\text { Constant WT\% }\end{array}$ \\
\hline V1 & Slurry Flow Control & Open & Same \\
\hline V2 & System Drain & Closed & Same \\
\hline V3 & BP Control & Closed & Same \\
\hline V4 & Filtrate Control & Open & Same \\
\hline V5 & Filtrate Sample Port (1) & Closed & Same \\
\hline V6 & BP Tank Air-Filtrate Egress \& Air Fill & Closed & Same \\
\hline V7 & Isolation & Open & Same \\
\hline V8 & Filtrate Flowmeter Drain & Open & Same \\
\hline V9 & Pump Air Supply & Open & Same \\
\hline V10 & Filtrate Direction (1) & To Separate Tank & To Feed Tank \\
\hline V11 & Building Air Supply & Open & Same \\
\hline \multicolumn{4}{|l|}{ Notes: } \\
\hline \multicolumn{4}{|c|}{$\mathrm{BP}=$ Backpulse } \\
\hline \multicolumn{4}{|c|}{ (1) Sampling or removing filtrate is generally taken from the filtrate exit } \\
\hline \multicolumn{4}{|c|}{ tube from valve $V 10$ so the filtrate pressure is not affected during } \\
\hline \multicolumn{4}{|c|}{ operation. The sample port at valve V5 is only an alternate, which was } \\
\hline not & ised in this test. & & \\
\hline
\end{tabular}

7.3 As CUF operation continues slurry valve V1 and air pump valve V9 may need periodic adjustment to maintain the flow condition. This may occur because of system vibration causing a valve position to change or may be due to the changing conditions of the filter medium, e.g., as a slurry concentration and more IS are present, accumulations of those solids may cause blockages, higher flow drag resistance, etc.

\subsection{Scouring}

Scouring is the process of shutting the filtrate flow valve, increasing the slurry axial velocity to $50 \%$ to $80 \%$ above the original set velocity, allowing the high velocity slurry to flow for approximately 10 to 15 minutes, then returning the velocity back to the original setting, and finally reestablishing filtrate flow over a 10- to 15-minute period. The steps used to perform a scouring are listed below: 
8.1 Close the filtrate valve V4.

8.2 Turn the slurry axial velocity up to $50 \%$ to $80 \%$ above the standard operating velocity by fully opening downstream slurry valve: V1 and increasing the slurry pump speed with valve V9. (Note, the velocity needed is $>11 \mathrm{ft} / \mathrm{s}$ X $1.5=16.5$ $\mathrm{ft} / \mathrm{s}$, or $>5.7 \mathrm{gpm}$.).

8.3 Allow the higher axial velocity to scour the filter cake for 15 to 20 minutes.

8.4 After the scouring period return the slurry axial velocity to its set operating value, e.g., $11 \mathrm{ft} / \mathrm{s}$ (3.8 gpm), by first returning the slurry pump to its original steadystate setting, with valve V9 and then slowly close slurry valve: V1 to its original setting to obtain 40 psid. Adjust both valves, V9 and V1 until the target flow parameters are obtained.

8.5 Reopen the filtrate valve, V4, very slowly over a period of approximately 10 to 15 minutes to full open. While opening note the increasing TMP and do not allow the TMP to increase sharply, that is, the pressure should be increased slowly and smoothly during the 15 minutes. Note, most of the pressure is obtained in the first $1 / 8^{\text {th }}$ turn of V4, which is between 0.3 and 0.5 turns because V4 has $\sim 2.5$ turns to full open. That is, the 10 to 15 minute opening time must be applied to the first $1 / 8^{\text {th }}$ turn.

8.6 Once again, readjust the slurry valve, V9 and V1, to obtain the chosen flow conditions, e.g., Axial Velocity of $11 \mathrm{ft} / \mathrm{s}(3.8 \mathrm{gpm})$ and TMP $=40 \mathrm{psid}$.

\subsection{Backpulsing}

Backpulse (BP) is the process of reversing the filtrate flow through the crossflow filter wall with the intention of pushing off the filter cake during filtration or help while cleaning the filter. It is done while the filter is in operation so the axial flow of slurry can carry away any cake that is released.

\section{Backpulse while filtering}

9.1 Ready the BP system

9.1.1 Ensure the BP system is not pressurized and prepare the BP tank to be filled by slowly orienting 3-way valve V6 to the slurry feed tank. Any pressurized gas in the BP tank will be relieved into the slurry feed tank. Leave V6 directed towards the slurry feed tank.

9.1.2 Open valve V3, and close valve V4, to direct filtrate into the BP tank.

9.1.3 When filtrate is seen exiting the BP tank through V6 and is entering the feed tank through the BP discharge line, then:

9.1.3.1 Close valve V3.

9.1.3.2 Slow down slurry pump using valve V9.

9.1.3.3 Fully open valve V1.

9.1.3.4 Adjust valve V9 to obtain an axial slurry velocity (SV) of about 5

to $9 \mathrm{ft} / \mathrm{s}$. (For this test it is obtained with approximately 1.7 to 3.1 gpm of flow).

9.1.4 Set the air regulator on the air supply to 2 times the slurry system pressure, $\mathrm{P} 2$. (For this test the BP pressure is set at 80 psig.) 
9.1.5 Orient valve V6 to the air supply to pressure the BP tank.

9.1.6 Orient valve V 6 to the off position- the BP system is ready to actuate.

9.2 Ensure valve V4 is closed.

9.3 Close valve V7 to isolate pressure transducer P3 from the pulse.

9.4 Have a stopwatch ready to time the BP.

9.5 Open valve V3 and start the stopwatch simultaneously.

9.6 Immediately close valve V3 to stop the BP after 8 seconds. (Note: Never allow the BP to occur for no more than 8 seconds. Longer times will allow air to enter the filtrate system which must be avoided. If air does enter the system the filtrate flux will be adversely affected once re-established. It will take time for the air to leave the system.)

9.7 Relieve residual pressure in the BP tank by directing valve V6 towards the feed tank. Leave valve V6 in that position.

9.8 Reopen valve V7 so that the filtrate pressure can be measured.

9.9 Reestablish filtration by very slowly opening valve V4 during a 10 to 15 -minute period. Note, most of the pressure is obtained in the first $1 / 8^{\text {th }}$ turn of V4, which is between 0.3 and 0.5 turns because V4 has $\sim 2.5$ turns to full open. That is, the 10 to 15 minute opening time must be applied to the first $1 / 8^{\text {th }}$ turn.

9.10 Readjust valves V1 and V9 to return the SV and TMP to their original settings.

\section{Backpulse while cleaning or when a larger BP is desired}

9.11 Steps 9.1 to 8.4 are the same.

9.12 Fully open valve V1 to drop the system pressure and increase the slurry flow.

9.13 Open valve V3 and start the stopwatch simultaneously.

9.14 Immediately close valve V3 to stop the BP after 8 seconds; however, closely observe the transparent filtrate tube that lies between the tee fitting just below valve V4 and fitting at the top of the filter housing to watch for air. If air is seen before the 8 seconds then close valve V3 immediately.

9.15 Reopen valve V7 so that the filtrate pressure can be measured.

9.16 If this BP was done during steady state slurry operation then readjust valve V1 to return to the target system pressure. It may be necessary to adjust valve V9 to readjust the pump speed.

\subsection{Shutting Down}

10.1 Close filtrate valve V4.

10.2 Stop the air flow to motor with valve V9.

10.3 Immediately close slurry valve V1 to prevent the slurry from draining from the filter tube.

10.4 Check to make sure the backpulse tank is not pressurized by directing 3-way valve, V6 to the feed tank. Caution: Turn very slowly to allow air to escape slowly to prevent any spraying or splashing of filtrate.

10.5 Shut off building air supply with valve V11. 
10.6 Direct valve V6 to the BP tank to allow any residual air pressure in the supply tube to be relieved into the BP tank, then re-direct valve V6 towards to feed tank to relieve any captured pressure.

\subsection{Draining CUF}

11.1 Place the drain tube extending from valve V2 into a collection container.

11.2 Open valves V1, V3, V7, V8, V 4, and 3-way valve V10 towards the feed tank. Direct 3-way valve V6 to the feed tank.

11.3 Collect slurry from the V2 drain by opening valve V2.

11.4 Continue 11.3 until most of the CUF contents have drained.

11.5 When no more slurry drains, then close valve V2.

11.6 Open and close pump valve V9 just enough for the slurry in the pump to flow into the feed tank. Close valve V9. Note, this action should be as brief as possible because extended periods of pump operation without liquid will damage the pump.

11.7 Drain the remaining slurry from the V2 drain by opening valve V2.

11.8 If the CUF testing is to continue then further draining is not necessary. It is important to leave the filter wet. However, if the test is complete, then air can be used to gentle remove the liquid portion of the slurry from the filtrate system.

11.8.1 With building air supply valve V11 open, slowly open 3-way valve V6 towards the air supply to allow air to flow through the BP tank and into the filtrate system.

11.8.2 The air should exit into the feed tank through V4 and V10.

11.8.3 The line to pressure transducer P3, can be drained by capturing the liquid out of the transducer discharge port. If more air pressure needed, first close valve V4, and then turn up gently, just enough to push any remaining liquid out. Close the transducer discharge port and reopen valve V4.

11.8.4 The previous step can be used to drain the small amount of liquid in the end of the filtration line from valve V5.

11.8.5 Finally, there is filtrate still in the filter housing and the pressure line between pressure transducers $\mathrm{P} 1$ and $\mathrm{P} 2$ and leading to $\mathrm{P} 1$. Some of that liquid can be gently pushed out of the housing by closing valves V4 and V 7 to push liquid through the filter and into the feed tank.

11.8.6 Then, by opening up the P1 pressure transducer discharge port the pressure line can be cleared of liquid. Close the discharge port.

11.8.7 When no more liquid enters the feed tank, there may be a little still left in the pump.

11.8.8 Close valve V6.

11.8.9 Open and close pump valve V9 just enough for the material in the pump to flow into the feed tank. Close valve V9 and then valve V11.

11.8.10Carefully direct 3-way valve V6 to feed tank to relieve an pressure between that valve and the pressure regulator.

11.8.11Open up valve V9 to relieve line pressure between the pump and the regulator. 
SRNL-STI-2014-00126

Revision 0

\section{Appendix C. CUF Test Matrix and Detailed Summary of Test Steps}

\begin{tabular}{|c|c|c|c|c|c|c|c|c|c|}
\hline Test & Test & Duration & UDS (5) & & Start Vol. & Measure & Velocity & TMP & \\
\hline Step & Solution & minute & $\mathrm{wt} \%$ & $\mathrm{pH}$ & liter & Filtrate & $\mathrm{ft} / \mathrm{s}$ & psid & Comment \\
\hline 1 & DIF-Water & NA & 0 & 5 & 4 & Yes & 11 & 40 & Start with clean system filled with water. Obtain filtrate flux \\
\hline 2 & $\mathrm{IH}$-Water & 15 & 0 & 12 & 5 & Yes & 11 & 40 & Add 4 grams of $50 \% \mathrm{NaOH}$ to water, measure $\mathrm{pH}$, then drain \\
\hline 3 & Simulant & 15 & Initial 0.8 & 14 & 5.5 & Yes (1) & 11 & 40 & Add Simulant, establish filter cake, take slurry sample \\
\hline 4 & Simulant & 120 to 240 & 0.8 to 1.6 & 14 & - & No (2) & 11 & 40 & Concentrate simulant \\
\hline 5 & Simulant & 15 & 1.6 & 14 & - & Yes & 11 & 40 & Steady state (SS) slurry concentration - take slurry sample \\
\hline 6 & Simulant & 120 to 240 & 1.6 to 3.2 & 14 & - & Yes & 11 & 40 & Concentrate simulant \\
\hline 7 & Simulant & 15 & 3.2 & 14 & - & Yes (3) & 11 & 40 & SS slurry concentration - take slurry sample - Add new batch \\
\hline 8 & Simulant & 15 & 3.2 & 14 & 6.5 & Yes (3) & 11 & 40 & SS slurry concentration - take slurry sample \\
\hline 9 & Simulant & 120 to 240 & 3.2 to 6.4 & 14 & - & Yes & 11 & 40 & Concentrate simulant - take filtrate sample \\
\hline 10 & Simulant & 15 & 6.4 & 14 & - & NA & 0 & 0 & Stopped - End of day \\
\hline $10 \mathrm{~A}$ & Simulant & 15 & 7 & 14 & - & No & 0 & 0 & Feed Tank down to $\sim 2.4$ liters - to be refilled with 2.3 liters \\
\hline 10B & Simulant & 15 & 7 & 14 & 4.7 & Yes (3) & 0 & 0 & Steady state slurry concentration - take slurry sample \\
\hline 11 & Simulant & 120 to 240 & 7 to 10 & 14 & - & Yes & 11 & 40 & Concentrate simulant - take filtrate sample \\
\hline 12 & Simulant & 15 & 10 & 14 & - & Yes & 11 & 40 & Steady state slurry concentration - take slurry sample \\
\hline 13 & Steps 13 a & ind 14 were & removed du & ue to & o the addit & ns of Ste & eps $10 A \&$ & $10 \mathrm{~B}, \mathrm{~s}$ & so that the remaining steps remained the same. The plan was \\
\hline 14 & changed at & t Step 10 to & added the la & ast b & patch at & t\% instea & $\mathrm{gd}$ of $10 \mathrm{wt}$ & $\%$. Th & his increased the volume in the feed tank to run more stable. \\
\hline 15 & Simulant & 120 to 240 & 10 to 15 & 14 & - & Yes & 11 & 40 & Concentrate simulant - take filtrate sample \\
\hline 16 & Simulant & 15 & 15 & 14 & - & NA & 0 & 0 & Stopped - End of day \\
\hline 17 & Simulant & 120 to 240 & 15 to $20(6)$ & 14 & - & Yes & 11 & 40 & Concentrate simulant - take filtrate sample \\
\hline 18 & Simulant & 15 & $20(6)$ & 14 & - & Yes & 11 & 40 & Steady state slurry concentration - take slurry sample \\
\hline 19 & Simulant & 15 & 10 & 14 & 4.2 & Yes & 11 & 40 & Replace filtrate, run SS slurry concentration - take sample \\
\hline 20 & Simulant & 15 & 10 & 14 & 4.2 & Yes & 11 & 40 & Backpulse filter and remeasure filtrate flux \\
\hline 21 & IH-Water & 15 & $<1$ & 12 & 4 & No & 11 & 40 & Add $4 \mathrm{~g}$ of $50 \% \mathrm{NaOH}$ to DIF-Water, measure $\mathrm{pH}$, then drain \\
\hline 22 & DIF-Water & 15 & $<1$ & 11 & 4 & No & 11 & 40 & Repeat flush - measure $\mathrm{pH}$ \\
\hline 23 & DIF-Water & 15 & $<1$ & 10 & 4 & No & 11 & 40 & Repeat flush - measure $\mathrm{pH}$ \\
\hline 24 & DIF-Water & 15 & 0 & 8 & 4 & Yes & 11 & 40 & Final flush - measure $\mathrm{pH}$ - measure filtate flux \\
\hline $24 \mathrm{~A}$ & DIF-Water & Repeat St & ep 24 until th & he p & $\mathrm{H}$ is equal & or less t & than 8 & & This minimized any precipitation from simulant in acid \\
\hline 25 & $1 \mathrm{MHNO}_{3}$ & $>480(4)$ & 0 & 0 & 4 & No & 11 & 40 & Acid clean \\
\hline 26 & $1 \mathrm{MHNO}_{3}$ & $>480(4)$ & 0 & 0 & 4 & Yes & 11 & 40 & Acid clean \\
\hline 27 & DIF-Water & 15 & 0 & 0 & 4 & No & 11 & 40 & Flush most of acid-measure $\mathrm{pH}$ \\
\hline 28 & DIF-Water & 15 & 0 & 1 & 4 & No & 11 & 40 & Repeat flush - measure $\mathrm{pH}$ \\
\hline 29 & DIF-Water & 15 & 0 & 4 & 4 & No & 11 & 40 & Repeat flush - measure $\mathrm{pH}$ \\
\hline 30 & DIF-Water & 15 & 0 & 5 & 4 & Yes & 11 & 40 & Final flush - measure $\mathrm{pH}$ - measure filtate flux \\
\hline
\end{tabular}

(1) The cake is established by very slowly circulating the slurry at approximately 1 to $2 \mathrm{ft} / \mathrm{s}(0.3$ to $0.7 \mathrm{gpm})$ until the filtrate system is filled. The TMP should be just enough to cause filtrate flow to occur. Once filtrate system is full the filtrate valve V 4 is closed. The slurry flow is increased to $11 \mathrm{ft} / \mathrm{s}$ and slurry pressure increased to $40 \mathrm{psid}$. When the slurry flow is steady, the filtrate valve, V4, is opened very slowly ( 15 minutes) to establish the filtrate cake by increasing the filtrate pressure in a steady and linearly in time until V4 is fully open. Care in opening V4 is important because most of the pressure come during the first quarter turn.

(2) After approximately 2 hours of operation (and when necessary) the filter should be scoured by shutting the filtrate flow, increasing the slurry velocity by $50 \%$ ( $16.5 \mathrm{ft} / \mathrm{s}$ or $5.8 \mathrm{gpm}$ ) for 15 minutes, then return the velocity to normal operation, i.e., $11 \mathrm{ft} / \mathrm{s}$, then re-establish filtrate flow very slowly over a 15-minute interval as based on the TMP. That is, the TMP should be increased smoothly as stated in Note (1). The system will not be backpulsed until necessary as determined by a flux $<0.01 \mathrm{gpm} / \mathrm{ft}^{2}$.

(3) When the slurry reaches the 1.25-liter level the next batch will be poured on top of the initial batch to complete a volume of 5 liters. A sample should be taken after the two batches are well mixed.

(4) Allowing the filter to soak for 24 to 36 hours is recommended.

(5) The initial UDS of the simulant is only a rough estimate; therefore, the concentrations given are only examples. In fact, the actual measurement turned out to be $0.53 \mathrm{wt} \%$ to start and $15 \mathrm{wt} \%$ at the end.

(6) The intention was to concentrate to $20 \mathrm{wt} \%$ but the test was terminated at an estimated $18.3 \mathrm{wt} \%$ because filtrate flow stopped principally because the flow conditions of TMP and the slurry velocity could not be maintained due to the higher solids loading.

Nomenclature: DIF = Deionized \& Filtered $(0.2 \mathrm{~mm})$ Water, $\mathrm{IH}=$ Inhibited Water $(0.01 \mathrm{M} \mathrm{NaOH}), \mathrm{TMP}=$ Transmembrane Pressure, NA=Not Applicable, $S S=$ Steady State 
SRNL-STI-2014-00126

Revision 0

Detailed summary of filtration test steps

The test steps discussed below refer to the preceding Test Matrix. References are also made to the CUF schematic, Figure 2-3.

1. On 11/11/2013, approximately 5.5 liters of simulant with an insoluble solids (IS) concentration estimated at $0.8 \mathrm{wt} \%$ (subsequently measured to be $0.5 \mathrm{wt} \%$ ) was introduced to the feed tank and slowly circulated in the CUF without filtering.

2. The slurry flow rate was kept low and with low transmembrane pressure (TMP) to slowly fill up the filtrate system by opening valve V4 over a 10-minute period; after which full filtrate flow was established.

3. TEST STEP 3: The flow conditions of TMP $=40 \mathrm{psid}$ and $\mathrm{SV}=11 \mathrm{ft} / \mathrm{s}$ were established and filtering began in recirculation mode. The first filtrate flux was measured to be 0.051 $\mathrm{gpm} / \mathrm{ft}^{2}$. Slurry and filtrate samples were collected.

4. TEST STEPS 4 and 5: Filtrate was diverted until the simulant volume was reduced to approximately $2.5 \mathrm{~L}$ in order to double the IS concentration to approximately $1.6 \mathrm{wt} \%$ (subsequently measured to be $0.9 \mathrm{wt} \%$ ). A filtrate sample was collected during the concentrating step, and slurry and filtrate samples were taken at the end of the concentration step.

5. TEST STEPS 6 and 7: Concentration continued until the simulant volume was reduced to approximately $1.3 \mathrm{~L}$ in order to again double the IS concentration to approximately 3.2 $\mathrm{wt} \%$ (subsequently measured to be $2.8 \mathrm{wt} \%$ ). A filtrate sample was collected during the concentration step, and slurry and filtrate samples were taken at end of the concentration step.

6. TEST STEP 8: Separately, an aliquot of simulant was settled and decanted to a target of $3.2 \mathrm{wt} \%$ IS. That concentrated slurry ( $5 \mathrm{~L}$ of $3.2 \mathrm{wt} \%$ IS) was then added to the CUF, matching the CUF contents at $3.2 \mathrm{wt} \%$ IS. Slurry samples were taken. (Note, the measured system volume was close to 6.5 liters at an estimated $3.2 \mathrm{wt} \%$ IS (again, it was subsequently measured to be $2.8 \mathrm{wt} \%$ ). )

7. TEST STEPS 9 and 10: Dewatering continued until the simulant volume was reduced to approximately $1 / 2$ in order to double the IS concentration to approximate $6.4 \mathrm{wt} \%$ (subsequently measured to be $5.6 \mathrm{wt} \%$ ). A filtrate sample was pulled during the dewatering and slurry and filtrate samples were taken at end of concentration.

8. TEST STEP 9: Part-way through this period, when the system volume had dropped to approximately 5.2 liters, the flux had decreased to approximately $0.023 \mathrm{gpm} / \mathrm{ft}^{2}$ so the operation was modified to scour the filter tube (Scouring is explained below) in an attempt to increase the flux. The scouring was effective, and afterwards the flux did improve to $0.028 \mathrm{gpm} / \mathrm{ft}^{2}$, a $40 \%$ increase.

9. TEST STEP 9: However, once the system volume dropped to approximately 4 liters, with an estimated IS concentration of $5.5 \mathrm{wt} \%$, the filtrate rate again returned to $\sim 0.020$ $\mathrm{gpm} / \mathrm{ft}^{2}$. Dewatering continued until the system volume dropped to approximately 3.2 liters and an approximate IS concentration of $6.5 \mathrm{wt} \%$.

10. TEST STEP 10: At this stage the test was stopped due to reaching the end of the work day, and system was shut down until the following day. 
11. The original test plan was to continue concentrating to attain a IS of approximately 12.8 $\mathrm{wt} \%$ by the end of the second batch and then a third batch would be added to reach 20 $w t \%$. However, when the system volume dropped to approximately 2.4 liters $(\sim 7 \mathrm{wt} \%$ IS), the feed tank exit port became partially exposed, leading to increased splashing. To overcome this issue, the third and final batch of 2.25 liters at $7 \mathrm{wt} \%$ was added to bring the total volume to $\sim 4.7$ liters. The larger simulant volume was more stable in the feed tank and minimized splashing. Before the 2.25 liters was added, slurry and filtrate samples were taken. After the 2.25 liters was added and mixed, another slurry and filtrate sample set was obtained. These samples were taken around 09:35 a.m.

12. TEST STEP 10A: Just before adding the batch of 2.25 liters of simulant mentioned in the preceding statement filtering had to stop because the system temperature could no longer be maintained below the maximum allowable temperature of $30^{\circ} \mathrm{C}$. The more viscous concentrated simulant was harder to cool and a larger capacity chiller was obtained and switched for the current one.

13. TEST STEP 10B: Once a more powerful chiller was obtained, dewatering began at approximately 10:15 a.m. with the newly combined simulant batches at $7 \mathrm{wt} \%$. Another pair of slurry and simulant samples was obtained. However, before restarting, the system was scoured again, which resulted in an established filter flux of $0.019 \mathrm{gpm} / \mathrm{ft}^{2}$. During the subsequent dewatering cycle, a filtrate sample was pulled at $\sim 12: 03$ p.m.

14. TEST STEP 11: By 12:10 p.m. the filter flux had dropped to approximately 0.011 $\mathrm{gpm} / \mathrm{ft}^{2}$.

15. TEST STEP 12: At 12:52 p.m. the IS concentration was estimated at $10 \mathrm{wt} \%$ at which time both slurry and filtrate samples were taken.

16. [Note, the original TEST STEPS 13 and 14 were skipped due to the addition of 10A and $10 \mathrm{~B}$ in order to maintain the remaining steps the same.]

17. After sampling at $10 \mathrm{wt} \%$ IS (subsequently measured to be $8.8 \mathrm{wt} \%$ ), the filtrate flux was measured at $0.0090 \mathrm{gpm} / \mathrm{ft}^{2}$, so a scouring was performed, after which the flux increased to $0.0113 \mathrm{gpm} / \mathrm{ft}^{2}$, a $25 \%$ increase.

18. TEST STEP 15: By 2:25 PM the simulant volume dropped to approximately 2.6 liters with an estimated IS concentration of $12 \mathrm{wt} \%$. A filtrate sample was obtained at $\sim 2: 20$ PM. With the high IS concentration both the TMP and SV were becoming harder to maintain. The filtrate flux was measured at $0.008 \mathrm{gpm} / \mathrm{ft}^{2}$.

19. TEST STEP 15: By 3:15 p.m. the simulant volume dropped to approximately 2.3 liters with an estimated IS concentration of $13.5 \mathrm{wt} \%$. The filtrate flux was measured, and had remained at $0.008 \mathrm{gpm} / \mathrm{ft}^{2}$.

20. TEST STEP 16: By 3:53 p.m. the simulant volume dropped to approximately 2.1 liters with an estimated IS concentration of $15 \mathrm{wt} \%$ (subsequently measured to be $13.8 \mathrm{wt} \%$ ). The filtrate flux was measured at $0.007 \mathrm{gpm} / \mathrm{ft}^{2}$. The pump had reached its operating limit, because although the TMP remained at an acceptable $\sim 38$ psid, the SV could only be maintained at approximately $9.5 \mathrm{ft} / \mathrm{s}$. Both a slurry and filtrate sample was obtained at 14:00 p.m.

21. The system was shut down for the day.

22. TEST STEP 17: On 11/13/2013 at 8:14 a.m. the system was restarted.

23. TEST STEP 17: At 8:45 a.m. the system volume was approximately 2 liters with an estimated IS of $16 \mathrm{wt} \%$. While the TMP was maintainable at approximately $40 \mathrm{psid}$, the 
$\mathrm{SV}$ had dropped to $\sim 9 \mathrm{ft} / \mathrm{s}$. The filtrate flux was measured at $\sim 0.005 \mathrm{gpm} / \mathrm{ft}^{2}$. Dewatering was initiated, and a filtrate sample was taken at 09:30 a.m.

24. TEST STEP 18: At 10:15 a.m. dewatering was stopped and the system was shut down. The simulant volume was estimated to be 1.7 liters and an approximate IS $=18.3 \mathrm{wt} \%$ (subsequently measured to be $14.8 \mathrm{wt} \%$ ). The SV was dropping rapidly, and the flow conditions were very erratic, perhaps due to solids building up and breaking down in valve V1. Because the superficial velocity dropped very low, to approximately $1 \mathrm{ft} / \mathrm{s}$, the system temperature began to increase because the heat energy could not be removed fast enough. A velocity of $6.5 \mathrm{ft} / \mathrm{s}$ was obtained, but only after dropping the TMP to $20 \mathrm{psid}$. This decrease in TMP essentially caused the filtrate flow to cease, thus ending the test.

25. TEST STEP 18: At 10:25 a.m., the final slurry and filtrate samples were taken.

26. Two small follow-on tests were performed immediately after terminating the primary test:

a. Effect of dilution on filtration (TEST STEP 19)

b. Effect of backpulsing (TEST STEP 20)

27. Dilution: To examine the effect of dilution, the filtrate that had been removed from the CUF after step 16 was returned to the feed tank and the system simulant volume was measured; it returned to the expected $\sim 4.2$ liters with an estimated $15 \mathrm{wt} \%$ IS. With this more dilute simulant, the flow parameters of TMP $=40 \mathrm{psid}$ and $\mathrm{SV}=11 \mathrm{ft} / \mathrm{s}$ once again could be established. At 12:00 PM a scouring cycle was performed, after which the filtrate flux was then measured at an approximately $0.004 \mathrm{gpm} / \mathrm{ft}^{2}$. After an hour of continuous recirculation, the flux did not improve and did not return to that observed in TEST STEP 16. It appears that the original flow rate could not be restored, suggesting that either a cake had built up on the filter, or, the simulant had changed character.

28. Backpulsing: After the dilution trial described above, several backpulses were performed in an attempt to restore the flux. Backpulsing steps are detailed below. The first time a backpulse was performed, the steps in the backpulse procedure were followed using an air pressure of $2 \times$ TMP, which was 80 psid and a pulse duration of 8 seconds. (This duration is based on the time that the air in the backpulse tank could reach the filter, which could be as short as about 9 seconds with a clean filter. Pulsing air backward into the filter element must be avoided because air in the filter significantly reduces filtrate flux.) The backpulse was not affective at all, as evidenced by a subsequent filtrate flux of $0.004 \mathrm{gpm} / \mathrm{ft}^{2}$, which is very low. The system was readied for a second backpulse, but it was observed that the backpulse tank was basically full, indicating that very little of the simulant in the backpulse tank flowed backward through the filter wall. It appears that the 80 psid pulse was not sufficient to remove the filter cake. For the second backpulse the maximum available pressure was used, 118 psid, and valve V3 was held open until air was observed at the entrance of the filter housing. At that pressure of backpulse, it took 2.5 minutes for the backpulse tank to empty, indicating no improvement. A final backpulse was performed, but this time the air pressure supply was not valved closed after pressurizing the backpulse tank, but was instead cycled at 1-second intervals at 118 psid. After 9 pulse cycles, or approximately 9 seconds, air was observed at the filter housing. The flux was measured at $0.0058 \mathrm{gpm} / \mathrm{ft}^{2}$, indicating that these high pressurized series of pulses were more effective than the preceding backpulse method, but still did not lead to a significant improvement in the filter flux. It is possible that the filter cake was fairly well secured onto the filter membrane, or that the shearing due to continuous 
recirculation during the $\sim 15$ hours of testing and thermal control issues, observed during TEST STEP 18, changed the morphology of the solids such that the original flux observed at $15 \mathrm{wt} \%$ IS was not restored. The expected flux at $15 \mathrm{wt} \%$ IS was $\sim 0.02$ $\mathrm{gpm} / \mathrm{ft}^{2}$.

29. TEST STEPS 21 to 24A: The CUF was drained of simulant and flushed with water until the $\mathrm{pH} \sim 7$. The solids were quite resilient, as can be seen in Figure 2-6, which shows large patches of grey solids in the bottom of the CUF feed tank.

30. TEST STEPS 25 to 26: The CUF was thoroughly cleaned with $1 \mathrm{M} \mathrm{HNO}_{3}$.

31. TEST STEPS 27 to 30: The acid was thoroughly flushed from the system with water until the $\mathrm{pH}>5$.

32. A clean water flux was measured, and the filter had returned to $\sim 0.6 \mathrm{gpm} / \mathrm{ft}^{2}$, Figure 2-7.

\section{$\underline{\text { Scouring }}$}

This is the process by which the filter tube is cleaned with a faster flow of slurry while no filtering occurs to shear away some of the top layers of the filter cake. The scouring process steps are as follows:

1. Filtrate flow is stopped by closing the filtrate outlet valve (V4).

2. Slurry velocity is increased to at least $50 \%$ over the current value. (For these tests, the $\mathrm{SV}$ was increased from 11 to $16 \mathrm{ft} / \mathrm{s}$ ). This is done in two steps:

a. Slurry concentrate valve (V1) is opened to drop the TMP and increase the SV.

b. Increase pump speed until the SV reaches the desired value $(16 \mathrm{ft} / \mathrm{s})$.

3. This high flow, lower pressure, operation is allowed to continue for 10 to 15 minutes.

4. Reset the standard flow conditions of TMP $=40 \mathrm{psid}$ and $\mathrm{SV}=11 \mathrm{ft} / \mathrm{s}$ by reversing steps $2 \mathrm{a}$. and $2 \mathrm{~b}$. above.

5. Slowly reestablish filtrate flow by slowly opening up valve V4 over a 10 to 15 minute period.

\section{$\underline{\text { Backpulsing }}$}

Backpulse (BP) is the process of reversing the filtrate flow through the crossflow filter wall with the intention of pushing off the filter cake during filtration or during chemical cleaning.

1. Ready the BP system (Refer do the CUF schematic, Figure2-3)

2. Ensure the BP system is not pressurized and prepare the BP tank to be filled by slowly orienting 3-way valve V6 to the slurry feed tank.

3. Slowly open valve V3 to direct filtrate into the BP tank.

4. When filtrate is observed exiting the BP tank, and begins entering the feed tank through the BP discharge line, then turn V6 to the off position.

5. Set the air regulator on the air supply to 2 times the slurry system pressure, $\mathrm{P} 2$.

6. Orient valve V6 to the air supply to pressurize the BP tank.

7. Orient valve V6 to the off position (the BP system is ready to actuate).

8. Close valve V4 to stop filtrate flow and prevent backpulse pressure from relieving through the filtrate exit line. 
9. Open valve V1 to lower the slurry pressure to maximize the effect of the backpulse pressure.

10. Open valve V3 and immediately start a stopwatch

11. Allow the BP to occur for no more than 8 seconds. (Note: longer times may allow air to enter the filter tube, which must be avoided.)

12. Immediately close valve V3 to stop the BP.

13. Reestablish filtration by very slowly by opening valve V4 during a 10 to 15 -minute period. (Note, most of the TMP is obtained in the first $1 / 8^{\text {th }}$ turn of V4,. That is, the 15 minute opening time applies to the first $1 / 8^{\text {th }}$ turn.)

14. Readjust valves V1 and V9 to attain the desired SV and TMP. 


\section{Appendix D. Filtrate Measurement Device}

One feature of the CUF use that differs from previous models is a 3-way valve installed atop the graduated cylinder used to measure the filtrate flow. Previously, measurements were made using the graduated cylinder during steady-state operation by flowing filtrate into the cylinder and out through drain valve V8. To make a measurement, valve V8 was closed to allow the cylinder to fill, measuring volume vs time. This method is generally accurate. However, when measuring high flow rates, the filtrate flow from the top of the cylinder greatly disturbs the air-liquid interface as it rises in the cylinder, and the interface is moving quite fast, making an accurate scale measurement difficult. To avoid this, a 3-way, V10, valve was installed at the same height as the filtrate entrance into the graduated cylinder to the secondary flow path going directly to the filtrate receipt container, as seen Figure D-1. Maintaining the same height of the valve and the accompanying tube to the top of the graduated cylinder was important to not disturb the filtrate backpressure, which affects the transmembrane pressure (TMP). The filtrate travels up to the top of the graduated cylinder, which was approximately two feet above the filter tube, or about 1 psi. Since all the tubing is at the same level, then switching between the calibrated cylinder and the tank return tubes should not affect the filtrate pressure, i.e., TMP. Now, V10 directs steady state filtrate flow past the graduated cylinder and into the tank. To make a measurement valve V8 is closed, then V10 directs filtrate to the cylinder until the filtrate reaches the lower graduated markings after which V10 is turned to again direct the flow past the cylinder. The graduated mark on the cylinder is recorded and the stop watch is zeroed. Finally, V10 redirects filtrate flow back to the cylinder concurrent with starting the stopwatch. When the filtrate reaches the upper portion of the cylinder, then V10 redirects the flow to the tank and stopwatch is stopped. This gives a very accurate way to obtain to a volume in the cylinder and the time to accumulate volume.

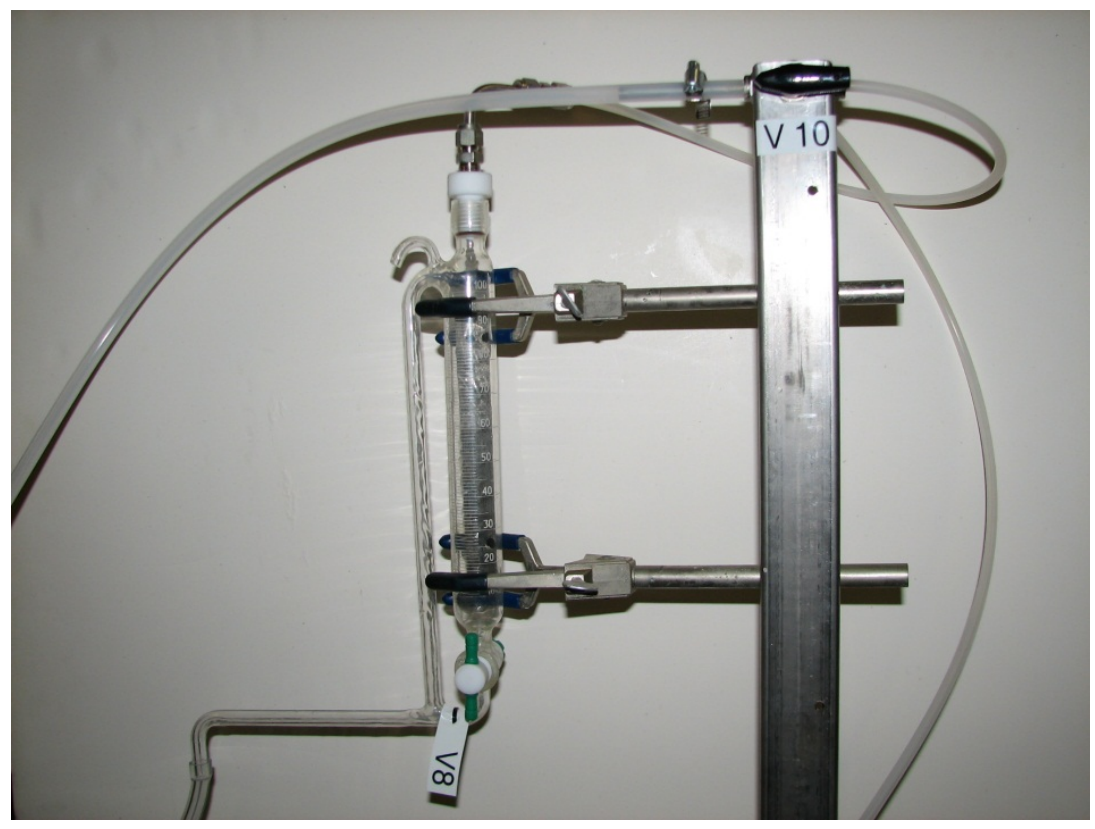

Figure D-1. Image of the graduated cylinder used to measure filtrate flowrate 


\section{Distribution:}

S. L. Marra, 773-A

F. M. Pennebaker, 773-42A

T. B. Brown, 773-A

D.H. McGuire, 999-W

S. D. Fink, 773-A

C. C. Herman, 773-A

E. N. Hoffman, 999-W

W. R. Wilmarth, 773-A

P. A. Cavanah, WRPS

D. J. Swanberg, WRPS

W.G. Ramsey, WRPS

A. D. Cozzi. 999-W

K. M. Fox, 999-W

R. A. Robbins, WRPS

R. M. Russell, WRPS

K. Subramanian, WRPS

Records Administration (EDWS) 